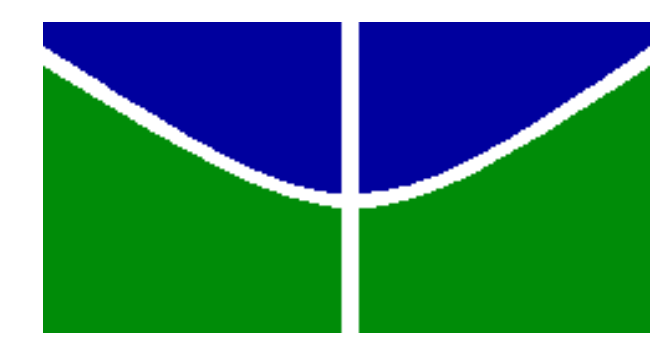

UNIVERSIDADE DE BRASÍLIA

FACULDADE DE EDUCAÇÃO

PROGRAMA DE PÓS-GRADUAÇÃO EM EDUCAÇÃO

MODALIDADE PROFISSIONAL - PPGE-MP

JOSEMAR DE ASSIS OLIVEIRA

A RELAÇÃO ENTRE O CONSELHO MUNICIPAL DE EDUCAÇÃO E O INSTITUTO FEDERAL DE GOIÁS (IFG) EM LUZIÂNIA - GO: UM ESTUDO DO CONTROLE SOCIAL NUMA PERSPECTIVA DEMOCRÁTICA

BRASÍLIA - DF, 2015. 


\section{A RELAÇÃO ENTRE O CONSELHO MUNICIPAL DE EDUCAÇÃO E O INSTITUTO FEDERAL DE GOIÁS (IFG) EM LUZIÂNIA - GO: UM ESTUDO DO CONTROLE SOCIAL NUMA PERSPECTIVA DEMOCRÁTICA}

Dissertação de Mestrado apresentada ao Programa de PósGraduação em Educação da Universidade de Brasília UnB, como requisito parcial para obtenção do título de Mestre em Educação. Área de concentração "Políticas Públicas e Gestão da Educação Profissional e Tecnológica", do Mestrado Profissional, sob a orientação do Professor Doutor Erlando da Silva Rêses.

BRASÍLIA - DF, 2015. 


\section{A RELAÇÃO ENTRE O CONSELHO MUNICIPAL DE EDUCAÇÃO E O INSTITUTO FEDERAL DE GOIÁS (IFG) EM LUZIÂNIA - GO: UM ESTUDO DO CONTROLE SOCIAL NUMA PERSPECTIVA DEMOCRÁTICA}

Dissertação apresentada ao Programa de Pós-Graduação em Educação Profissional da Faculdade de Educação da Universidade de Brasília, como parte dos requisitos para obtenção do título de Mestre em Educação.

\section{Banca Examinadora:}

Professor Dr. Erlando da Silva Rêses - Orientador Faculdade de Educação - FE/UnB

Professor Dr. Perci Coelho de Souza - Membro Interno

Departamento de Serviço Social - SER/UnB

\footnotetext{
Professora Dra. Caroline Soares Santos - Membro Externo IFG - Campus Luziânia - GO
}

Professora Dra. Adriana Sales de Melo -Suplente Faculdade de Educação - FE/UnB

Aprovado em 23/11/2015. 
Ficha catalográfica elaborada automaticamente, com os dados fornecidos pelo(a) autor(a)

OLIVEIRA, JOSEMAR DE ASSIS
OOL48r A RELAÇÃO ENTRE O CONSELHO MUNICIPAL DE EDUCAÇÃO E O INSTITUTO FEDERAL DE GOIÁS (IFG) EM LUZIÃNIA GO: UM ESTUDO DO CONTROLE SOCIAL NUMA PERSPECTIVA DEMOCRÁTICA / JOSEMAR DE ASSIS OLIVEIRA; orientador Dr. Erlando da Silva Rêses . -- Brasilia, 2015. $126 \mathrm{p}$.

Dissertação (Mestrado - Mestrado em Educação) -Universidade de Brasilia, 2015.

1. Educação Profissional e Tecnológica. 2. Participação Popular. 3. Controle Social. 4. Democracia e Municipio de Luziânia.. I. Rêses, Dr. Erlando da Silva, orient. II. Título. 
Dedico essa dissertação: aos entes queridos Sílvio, Suely, Zé Osvaldo, Tio Tom, Vó Espertina, Tia Alaíde, Tio João, Célia e Dona Marina (mãe querida), pois, sem ela, não chegaria até aqui...

Estou muito feliz. Realizar sonhos é cumprir, ainda que parcialmente, os desígnios de Deus... Ser Mestre com alma de eterno aprendiz... Viver e não ter a vergonha de ser feliz, já dizia o saudoso Gonzaguinha. 


\section{AGRADECIMENTOS}

Agradeço primeiramente a Deus e à minha família, pelo amor incondicional e apoio irrestrito nesta caminhada repleta de desafios, percalços e perspectivas;

Aos meus amigos e amigas pela estima, consideração e ensinamentos cotidianos... nomeá-los aqui seria um risco ingênuo de cometer injustiças, cada um e cada uma sabe quem é e qual lugar ocupa em meu coração;

Agradeço ao Instituto Federal de Goiás, local de trabalho, pela generosidade e disponibilidade dos gestores, servidores, professores e discentes, fonte de inspiração no percurso árido e fértil na busca e construção do conhecimento;

Ao Conselho Municipal de Educação em Luziânia, local de enfoque da pesquisa, pela grande contribuição dos conselheiros, assessorias e demais funcionárias;

Ao Programa de Pós-Graduação em Educação da Universidade de Brasília - UnB, pela oportunidade, tão almejada, desde a adolescência nas periferias de Teófilo Otoni - MG e imediações;

Aos professores e demais colaboradores neste percurso iniciado na seleção do Mestrado no segundo semestre de 2013 e também aos Irmãos Maristas pelo acolhimento e hospedagem solidária em todo o percurso do Mestrado;

Ao meu orientador, Professor Doutor Erlando da Silva Rêses, pelas contribuições, paciência, generosidade, confiança, críticas e ensinamentos, que levarei para o decorrer da vida...

E também aos professores avaliadores das bancas de qualificação e defesa pelas críticas, contribuições e ponderações pertinentes, necessárias em tempos de construção e aprendizado contínuo, destacando aqui os Professores Perci Coelho e Caroline Soares... Que o Doutorado seja algo palpável após esta conquista do Mestrado em Educação, pois a sede do saber e da procura do "ser" não cessa nunca... valeu!

E finalmente ao Seu Zé de Eurico, meu pai, meu herói, essa vitória é sua, com o advento da comemoração dos seus 80 anos de vida e sabedoria... seu filho Chiquinho, o "caçula atentado", cresceu e saiu pelo mundo, mas em breve voltará para casa, com fé em Deus, para conviver com o senhor e com a nossa família e amigos da vida toda... nunca foi fácil pai, mas Deus sempre cuidou dos meus passos, colocando pessoas iluminadas no caminho e quer saber a verdade, Doutorado em Educação quem merece é o senhor e minha mãe (in memorian), por tudo que ensinaram pros filhos, netos, sobrinhos e agregados...amo vocês... "Amor, humor" (Drummond) 


\section{Cidadão}

\section{(Zé Geraldo)}

Tá vendo aquele edifício moço?

Porque que eu deixei o norte

Ajudei a levantar

Eu me pus a me dizer

Foi um tempo de aflição

Eram quatro condução

Lá a seca castigava mas o pouco que eu plantava tinha direito a comer

Duas pra ir, duas pra voltar

Hoje depois dele pronto

Olho pra cima e fico tonto

Mas me chega um cidadão

E me diz desconfiado, tu tá aí admirado

Ou tá querendo roubar?

Meu domingo tá perdido

Vou pra casa entristecido

Dá vontade de beber

E pra aumentar o meu tédio

Eu nem posso olhar pro prédio

Que eu ajudei a fazer

Tá vendo aquele colégio moço?

Eu também trabalhei lá

Lá eu quase me arrebento

Pus a massa fiz cimento

Ajudei a rebocar

Minha filha inocente

Vem pra mim toda contente

Pai vou me matricular

Mas me diz um cidadão

Criança de pé no chão

Aqui não pode estudar

Esta dor doeu mais forte

Enchi o rio fiz a serra

Não deixei nada faltar

Hoje o homem criou asas

E na maioria das casas

Eu também não posso entrar

Fui eu quem criou a terra

Enchi o rio fiz a serra

Não deixei nada faltar

Hoje o homem criou asas

E na maioria das casas

Eu também não posso entrar 


\section{MEMORIAL}

São quase 43 anos de caminhada para chegar até aqui. Tudo começou com a infância pobre e divertida em Pedro Versiani, Distrito de Teófilo Otoni, Nordeste de Minas Gerais, em pleno Vale do Mucuri.

Depois veio a adolescência nas periferias de Teófilo Otoni, jogando futebol e tomando banho nos rios, que ainda respiravam naquela época. Aos 15 anos, cursando o primeiro ano do ensino médio na Escola Estadual Tristão da Cunha, tive o privilégio de conhecer a experiência do Grupo de Jovens "Chico Mendes", na Casa Emaús, ligada ao Projeto Aprender Produzir Juntos - APJ, fruto dos trabalhos de fé e política do Padre Giovanni Lisa, um sábio italiano que me ensinou a pensar crítica e politicamente.

Depois, com 17 anos, a passagem como funcionário da Companhia Energética de Minas Gerais - CEMIG, mostrou o lado sério da vida, sendo leiturista, eletricista e técnico em Almoxarifado por 7 anos, de muito aprendizado e lutas no Sindicato e na CIPA (Segurança do Trabalho).

Em meados de 1997, após vivenciar experiências pessoais e profissionais nas cidades de Sete Lagoas, Teófilo Otoni, Nanuque e Belo Horizonte (todas em Minas Gerais), descubro o mundo do Serviço Social, sendo aprovado na PUC Minas, em Belo Horizonte... Após a conclusão do curso de Serviço Social em 2002, perpassando por estágios e trabalhos como Educador Social na Associação de Catadores de Materiais Recicláveis (ASMARE), Superintendência de Limpeza Urbana (SLU) e Casa da Acolhida Marista de Belo Horizonte MG (Obra social ligada ao Colégio Dom Silvério) resolvo que é hora de voltar pra casa, em julho do referido ano.

O trabalho com os Maristas, lidando com crianças e adolescentes em situação de risco pessoal e social, me humanizou e até hoje mantenho contatos com as crianças e adolescentes da época, hoje homens e mulheres. Um deles, Welbert, me adotou como pai e eu o adotei como filho do coração.

Logo depois, voltando pra casa, descubro a riqueza de ser pai biológico de um menino lindo de quase 9 anos de idade, Rafael, e como Deus nos ensina com provações, vivencio a tristeza dos passamentos da minha mãe, Dona Marina (10 de setembro de 2002) e da minha irmã Suely (22 de dezembro de 2002).

Paralelamente a tudo isso, começa a trajetória profissional nas cidades de Novo Oriente de Minas, Poté, Teófilo Otoni, Itaipé, Frei Gaspar, Pavão, Belo Horizonte, Betim, 
Acaiaca, Montes Claros, Brasília, Francisco Badaró e Luziânia. As experiências de trabalhos como Assistente Social, Assessor Técnico do Ministério do Desenvolvimento Social (MDS), Secretário Municipal de Assistência Social, Professor, Coordenador e Agente Fiscal me proporcionaram conhecer a realidade de muitas pessoas e isso marcou a minha a vida, até aqui. Fruto das experiências como docente no Serviço Social na Doctum Deus me presenteou com outro filho de consideração e afeto, Marcus Vinícius, ex-aluno, menino que me orgulha muito, atualmente Assistente Social do Tribunal Regional do Trabalho em Belo Horizonte MG.

No período de 2002 a 2013 atuou como presidente e conselheiro municipal nas áreas de assistência social, educação e criança e adolescente. As especializações em Gestão Social (Doctum) e História e Culturas Políticas (UFMG) e as disciplinas isoladas do Mestrado em Desenvolvimento Social (Unimontes) me qualificaram para enfrentar os desafios do Mestrado em Educação na Universidade de Brasília - UnB. Vale ressaltar que a escolha do tema se deu pela militância em movimentos sociais, que culminou na pesquisa da relação do Conselho Municipal de Educação com o Instituto Federal de Goiás - Câmpus Luziânia.

O sonho que está sendo realizado de ser Mestre em Educação mostra o quanto cada detalhe faz a diferença. Várias pessoas, de todas as idades, crenças e formações, me auxiliaram e mais do que isso, me mostraram que tudo tem valido a pena. Continuo ávido em aprender... Mais do que títulos, quero sempre ter o dom de conquistar amizades e contribuir com o crescimento das pessoas. Essa foi a grande missão apreendida com a opção de ser Assistente Social: Gostar de gente... Gente é sempre um desafio... Gente é sempre diferente!!! Amigos recentes e antigos, essa vitória é nossa, não conseguiria sem o apoio irrestrito e incondicional de cada e cada uma, com releituras dos textos, apoio financeiro, orações, paciência, palavras motivadoras em tempos de desesperança... Estou simplesmente feliz e quero mais uma vez agradecer a Deus, pelo dom da vida e por mais essa conquista!!! 


\section{RESUMO}

A cidade de Luziânia, situada no Entorno do Distrito Federal, divisa entre Goiás e Brasília, é um lugar histórico com 268 anos de existência. Neste contexto, desde 2010, com a política governamental de expansão da educação profissional e tecnológica no Brasil, foi instituído o Campus do Instituto Federal de Goiás (IFG), num local estratégico da cidade, Vila Esperança, local periférico, que vem sendo transformado gradativamente com o desenvolvimento do IFG. Proporcionando aos adolescentes, jovens e adultos a possibilidade de se inserirem nos Cursos Técnicos Integrados, Superiores e na modalidade de Jovens e Adultos, popularmente conhecido como EJA. Partindo do pressuposto de que os espaços educacionais são territórios que conferem aos estudantes possibilidades e perspectivas de melhoria das condições de vida e trabalho, optou-se por pesquisar a relação entre o Conselho Municipal de Educação e o IFG em Luziânia, analisando se há elementos que evidenciam controle social, participação e democracia nesta supracitada relação. A pesquisa se justifica pela necessidade de buscar compreender se o Conselho Municipal, cuja representatividade é contemplada também por um membro indicado pelo IFG, vem, de fato, cumprindo o seu papel orientador, normatizador e fiscalizador no âmbito da Educação. Para o desenvolvimento deste trabalho, foram entrevistados os 11 Conselheiros Municipais e o Gestor representante do Instituto, para maior compreensão dessa relação. Foi feito ainda pesquisa bibliográfica e documental sobre o tema, analisando o conteúdo das atas, regimentos e pareceres do Conselho no período de outubro de 2013 a abril de 2015, que contempla o trabalho da atual Gestão. Os resultados obtidos permitem considerar que esta relação analisada comprova uma das hipóteses levantadas inicialmente, sustentando que a presença do IFG dentro do Conselho Municipal de Educação se expressa em protagonismo, empoderamento e contributos para a realização da função social do referido órgão representativo. A proposição do Observatório da Educação como produto técnico e intervenção na realidade visa materializar este trabalho científico.

Palavras-Chave: Educação Profissional e Tecnológica, Participação Popular, Controle Social, Democracia e Município de Luziânia. 


\begin{abstract}
The city of Luziânia, surrounding the Federal District, boundary between Goiás and Brasília, is a historical place, having over 268 years of existence. In this context, since 2010, with the government policy of expansion of vocational and technological education in Brazil it was set up the Federal Campus of the Institute of Goiás (IFG), in a strategic city location, Vila Esperança in a peripheral site, which has been changed gradually with the development of the IFG. Enabling adolescents, young people and adults, the possibility of inserting themselves into the Integrated Technical Courses, the Superior courses and into the mode of youth and Adult courses, popularly known as EJA. Assuming that the educational spaces are territories, which confer students the possibility and the perspective of improving conditions of life and work, it was decided to investigate the relationship of the City Board of Education with IFG in Luziânia, analyzing whether there are elements that show social control, participation and democracy in this aforementioned relationship. The research is justified by the need of seeking to understand if the Municipal Council, which representativeness is also contemplated by a member appointed by the IFG, is indeed fulfilling its guiding role, normalizing and controlling features in the Education field. For the development of this work, we interviewed the 11 Municipal Counselors and the representative Manager of the Institute, for a better understanding of this relationship. It was also done a bibliographical and documentary research on the topic, analyzing the content of the minutes, regiments and opinions of the Council from October 2013 to April 2015, which includes the work of the current management. The obtained results support the conclusion that the analyzed relationship confirms one of the initial hypotheses maintaining that the presence of IFG within the City Board of Education is expressed in protagonism, empowerment and contributors to the implementation of the social function of the said representative body. The proposition of the Education Observatory as a technical product and intervention in reality aims to materialize this scientific work.
\end{abstract}

Keywords: Professional and Technological Education, Popular Participation, Social Control, Democracy and Municipality of Luziânia . 


\section{LISTA DE ABREVIATURAS}

\begin{tabular}{|c|c|}
\hline AMUNPAR & Associação dos Municípios do Noroeste do Paraná \\
\hline $\mathrm{BPC}$ & Benefício de Prestação Continuada \\
\hline CAGI & Custo Aluno Qualidade Inicial \\
\hline CAPES & Coordenação de Aperfeiçoamento de Pessoal de Nível Superior \\
\hline $\mathrm{CF}$ & Constituição Federal da República Democrática do Brasil \\
\hline CMAS & Conselho Municipal de Assistência Social \\
\hline $\mathrm{CME}$ & Conselho Municipal de Educação \\
\hline CNAS & Conselho Nacional de Assistência Social \\
\hline $\mathrm{CNE}$ & Conselho Nacional de Educação \\
\hline CODEPLAN & Companhia do Planejamento do Distrito Federal \\
\hline CRAS & Centros de Referência da Assistência Social \\
\hline CREAS & Centro de Referência Especializado de Assistência Social \\
\hline DF & Distrito Federal \\
\hline ECA & Estatuto da Criança e do Adolescente \\
\hline EJA & Educação de Jovens e Adultos \\
\hline ЕРCT & Educação Profissional, Científica e Tecnológica \\
\hline EPT & Educação Profissional e Tecnológica \\
\hline FDDCA - MG & $\begin{array}{l}\text { Frente de Defesa dos Direitos da Criança e do Adolescente de Minas } \\
\text { Gerais }\end{array}$ \\
\hline FGTS & Fundo de Garantia por Tempo de Serviço \\
\hline FUNDEB & $\begin{array}{l}\text { Fundo de Manutenção e Desenvolvimento da Educação Básica e de } \\
\text { Valorização dos Profissionais da Educação }\end{array}$ \\
\hline FUNDESCOLA & Fundo de Fortalecimento da Escola \\
\hline $\mathrm{GO}$ & Goiás \\
\hline IBGE & Instituto Brasileiro de Geografia e Estatística \\
\hline IFG & Instituto Federal de Educação, Ciência e Tecnologia de Goiás \\
\hline LDB & Lei de Diretrizes e Bases da Educação \\
\hline LDBEN & Lei de Diretrizes e Bases da Educação Nacional \\
\hline MEC & Ministério da Educação \\
\hline MERCOSUL & Mercado Comum do Sul \\
\hline ONU & Organização das Nações Unidas \\
\hline PAC & Programa de Aceleração do Crescimento \\
\hline PAIF & Programa de Atenção Integral à Família \\
\hline PDDE & Programa Dinheiro Direto na Escola \\
\hline PIB & Produto Interno Bruto \\
\hline PMDB & Partido do Movimento Democrático Brasileiro \\
\hline PME & Plano Municipal de Educação \\
\hline PNAE & Programa Nacional de Alimentação Escolar \\
\hline PNATE & Programa Nacional de Apoio ao Transporte Escolar \\
\hline PNDR & Política Nacional de Desenvolvimento Regional \\
\hline PNE & Plano Nacional de Educação \\
\hline PROAFEM & Programa de Apoio Financeiro às Escolas Públicas Municipais \\
\hline PROEP & Programa de Expansão da Educação Profissional \\
\hline
\end{tabular}


PRONATEC Programa Nacional de Acesso ao Ensino Técnico e Emprego

PSDB

PT Partido Social da Democracia Brasileira

PTA

Partido dos Trabalhadores

RIDE Programa de Trabalho Anual

SCIELO

Região Integrada de Desenvolvimento do Distrito Federal e Entorno

SEDESE - MG Scientific Electronic Library Online

SETEC

Secretaria de Estado e Desenvolvimento Social de Minas Gerais

SUAS

Secretaria de Educação Profissional e Tecnológica do Ministério da Educação

SUS

Sistema Único de Assistência Social

UEG

Sistema Único de Saúde

$\mathrm{UnB}$

Universidade do Estado de Goiás

UNIDERP

Universidade de Brasília

UNIDESC

Universidade Anhanguera

USAID

Centro Universitário de Desenvolvimento do Centro-Oeste

Agência dos Estados Unidos para o Desenvolvimento Internacional 


\section{SUMÁRIO}

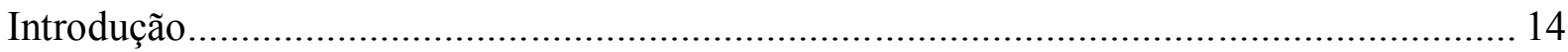

Capítulo I - Metodologia e Marco Teórico da Pesquisa ....................................................... 17

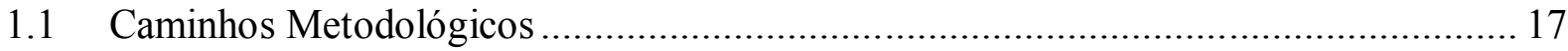

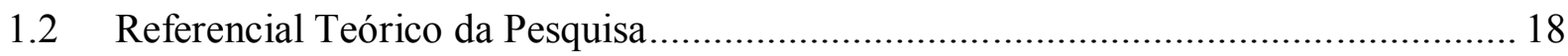

1.3 Objetivos, Problematização e Hipótese ....................................................................... 22

Capítulo II - Estado, Políticas Públicas e Controle Social ................................................... 23

2.1 Breve Histórico das Políticas Públicas no Brasil ...................................................... 23

2.2 Política Pública, Política Social e Política: Um Debate Necessário ............................ 29

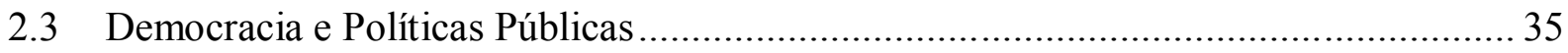

2.4 Participação Popular e Controle Social: O Papel dos Conselhos ................................ 37

2.5 Políticas Públicas de Educação no Brasil................................................................ 43

2.6 Educação Profissional e Tecnológica: Os Desafios da Expansão no Brasil .................. 48

2.7 A Contextualização Histórica do Câmpus do IFG em Luziânia - GO .......................... 53

2.7.1 A Cidade de Luziânia-GO: Breve Histórico ........................................................... 55

2.7.2 Aspectos Sociais em Luziânia - GO ……........................................................... 57

2.7.3 Aspectos Educacionais do Município de Luziânia - GO...................................... 60

2.8 O Conselho Municipal de Educação em Luziânia - GO: Caracterização e História ..... 66

Capítulo III - A Relação entre o Conselho Municipal de Educação e o Instituto Federal de Goiás (IFG) em Luziânia - GO: Um Estudo de Caso ..................................................... 71

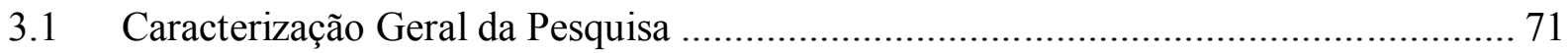

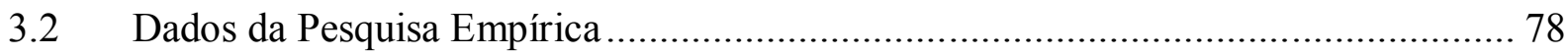

3.3 Diálogo com os Conselheiros Municipais de Educação e Gestão do IFG .................. 81

Capítulo IV - Ferramenta de Aplicabilidade Social - Produto Técnico............................... 90

4.1 Observatório da Educação em Luziânia - GO ...................................................... 90

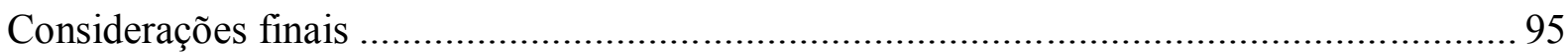

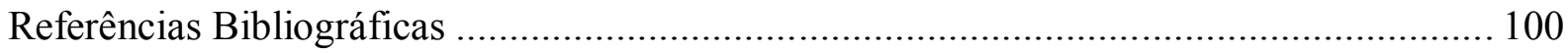

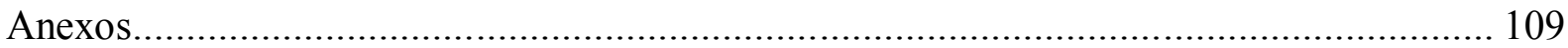

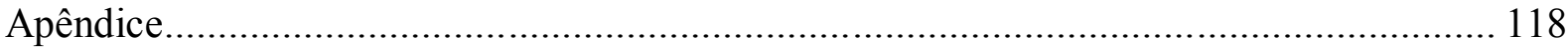




\section{Introdução}

Esta pesquisa dissertativa busca expressar a compreensão das atividades das entidades e instituições que representam a sociedade civil, englobando os movimentos sociais e populares e a relação híbrida de tal representação com o Estado. O presente estudo visa analisar a participação do Instituto Federal de Goiás como contributo do cumprimento e efetividade da função social do Conselho Municipal de Educação em Luziânia - GO, objetivando contribuir para maior interlocução e fortalecimento das redes de atendimento educacional e de proteção social, na perspectiva de aprimoramento contínuo da qualidade dos serviços prestados aos usuários das políticas públicas educacionais, conforme preconiza a Constituição Federal de 1988.

A pesquisa avaliativa em Políticas Públicas terá como categorias de análise a participação popular e o controle social. A proposta da pesquisa consiste em investigar a efetividade da participação dos atores sociais da sociedade civil e do governo, incluindo representantes do Instituto envolvidos no Conselho Municipal de Educação em Luziânia GO. Ressalta-se que os Conselhos são partes e instrumentos de efetivação das Políticas Públicas, por meio da participação da sociedade civil nos processos de formulação e gestão de políticas sociais, bem como o envolvimento da sociedade civil na formulação da agenda pública, na físcalização, monitoramento e avaliação destas políticas nas esferas governamentais. Vale ainda apreender a relevância dos assuntos relacionados às políticas públicas no cenário brasileiro, sobretudo a partir da Constituição Cidadã, que propiciou a inserção de novos contornos às ações do Estado, pautado em ideais participativos, democráticos e de descentralização.

Sob esta perspectiva, se torna imprescindível compreender as nuances da relação existente desde a implantação do Campus do IFG em Luziânia com os diversos Conselhos Municipais locais. Destarte, esta pesquisa busca enfocar a Educação, uma vez que o Instituto tem representatividade ativa, na implementação, formulação e avaliação das políticas públicas locais e regionais. Política pública, na concepção de Dias e Matos (2012), perpassam por um processo no qual se define os motivos da inclusão na agenda governamental, indicando a escolha de certos caminhos, pretendendo alcançar determinados objetivos que são de interesse comum de toda a sociedade. 
Segundo Dias e Matos (2012), políticas públicas podem ser compreendidas ainda como propostas articuladas que orientam as decisões de um governo para atingir um objetivo determinado. Toda política pública deve estar sustentada por um corpo teórico que oriente os cursos da ação que se propõe, bem como a tomada de decisões, o estabelecimento de prioridades e a destinação de recursos públicos.

Os referidos autores defendem ainda que os Conselhos são organizações institucionais setoriais ou temáticas, de caráter consultivo e/ou deliberativo e fiscalizador, com finalidade de produzir e acompanhar as políticas públicas no âmbito do governo. São arranjos institucionais com feições novas, porque não são meramente comunitários e não são meramente estatais. Tem caráter compartilhado na formulação, gestão, controle e avaliação das políticas públicas, com participação igualitária na tomada de decisões, visando a descentralização das ações, pós-Constituição de 1988. Os Conselhos se constituem, sobretudo, como espaços públicos de composição plural e paritária entre Estado e sociedade civil, de natureza deliberativa, cuja função é formular e controlar a execução das políticas públicas setoriais. Em todas as municipalidades, como em Luziânia, Goiás, os Conselhos são criados por lei municipal e caracterizam-se como importantes mecanismos que asseguram a participação, gestão e controle por parte da sociedade na consolidação das políticas públicas.

Essa dissertação de pesquisa em educação foi dividida em quatro capítulos, com as seguintes temáticas:

A) Referenciais teóricos e metodológicos da pesquisa avaliativa em políticas públicas, tendo a participação popular e o controle social como principais categorias de análise embasando o Capítulo I, intitulado como "Metodologia e Marco Teórico da Pesquisa".

B) Marco teórico, visando conceituar e compreender os significados de Política, Política Social e Políticas Públicas e a interface dessas temáticas com Estado, Democracia, Participação Popular e Controle Social, visando embasar os desafios da Educação (CF 88 e LDB) e da expansão da Educação Profisssional e Tecnológica - EPT no Brasil. Tentando atingir tal desafio teórico, definimos o Capítulo II como "Estado, Políticas Públicas e Controle Social".

C) No Capítulo III, optamos em destacar a pesquisa de campo, onde definimos identificar a abordagem qualitativa da relação do Conselho Municipal de Educação com Instituto Federal de Goiás como estudo de caso. O título do 
Capítulo ficou definido como "A relação entre o Conselho Municipal de Educação com o Instituto Federal de Goiás (IFG): um Estudo de Caso ”.

D) O quarto e último Capítulo, na estruturação da dissertação ficou como lócus do produto técnico, definido como ferramenta de aplicabilidade social, a qual denominamos como "Observatório da Educação", cujo principal objetivo será propiciar maior difusão da história de Luziânia e proporcionar maior interlocução entre sociedade, Conselho Municipal de Educação e Instituto Federal de Goiás.

Diante do exposto, vale ressaltar que a experiência da relação entre o Conselho Municipal de Educação e o IFG, a priori, indica caminhos que apontam para uma possível gestão democrática com participação popular, em prol do desenvolvimento local na cidade de Luziânia-GO. Procura, também, fomentar a participação efetiva de toda a comunidade, para que a mesma tenha vez e voz nos espaços de debates e tomada de decisões, culminando na criação de um "Observatório da Educação", que possa contribuir para maior difusão sobre a história da cidade e os serviços inerentes à política pública de Educação, advindos da interlocução em processo de construção entre o Conselho Municipal de Educação e o IFG. 


\section{Capítulo I - Metodologia e Marco Teórico da Pesquisa}

\subsection{Caminhos Metodológicos}

Esta pesquisa é um estudo de caso de natureza qualitativa que visa fundamentar os posicionamentos críticos e políticos que constam nos referenciais teórico e metodológico, com o intuito de compreender a participação dos sujeitos da pesquisa (Conselheiros Municipais de Educação) a partir de duas dimensões:

a) Objeto de análise (Estudo de Caso);

b) Projeto de intervenção - possibilidades de intervenção desta participação a partir da proposição de uma ação de intervenção na realidade do município de Luziânia - GO (Observatório da Educação).

Em relação à opção na utilização do Estudo de caso como objeto de análise da relação entre o Conselho Municipal de Educação (CME) e o Instituto Federal de Goiás (IFG) na cidade de Luziânia - GO, localizada no entorno de Brasília - Distrito Federal, ampara-se nas reflexões do André (2005), uma vez que o mesmo defende que o conhecimento gerado a partir desta modalidade de estudo proporciona maior contextualização aos fatos reais oriundos dos grupos escolhidos, permitindo apreender suas particularidades. O Estudo de Caso na perspectiva do referido autor ao retratar situações reais sem prejuízo da sua dinamicidade natural oferece uma grande contribuição aos problemas advindos das práticas educacionais, ao proporcionar informações que possam subsidiar e validar decisões políticas e reelaborar relações, conceitos e compreender uma realidade específica que pode ser generalizada.

Obstante, ressalta-se ainda que esta abordagem dialoga com outras metodologias, a saber: o estudo sobre o estado da arte defendido por Ferreira (2002); a pesquisa bibliográfica conforme disposto em Gil (2002) e entrevistas de acordo com Bardin (1977).

A pesquisa originou-se de ampla investigação sobre o assunto:

I. Das fontes bibliográficas compreendendo: a) livros acadêmicos; b) artigos científicos; c) trabalhos monográficos de teses e dissertações acadêmicas;

II. Relatório de pesquisa a textos que dialogam com os Conselhos Municipais de Políticas Públicas;

III. Fontes documentais: a) Projetos Políticos Pedagógicos e Planos Escolares; b) Pareceres, resoluções e regimento interno do Conselho Municipal de Educação; 
IV. Fontes orais: a) Entrevistas com os Conselheiros Municipais de Educação e com o Diretor-Geral do Instituto Federal de Goiás - IFG, Câmpus Luziânia - GO.

A pesquisa qualitativa, conforme Berg (1998), diz respeito aos significados, conceitos, definições, características, metáforas, símbolos e descrição das coisas. As principais técnicas utilizadas na perspectiva da pesquisa qualitativa são: observação participante, entrevista, técnicas fotográficas, vídeo, análise histórica (historiografia), análise de textos e documentos, sociometria, sociodrama, pesquisas etnográficas, experimentos etnometodológicos.

No que tange ao procedimento de análise de conteúdo, ressalta-se que este estudo está pautado em Bardin, quando a mesma afirma que tal análise está embutida num processo duplo-facetário, ou seja:

Compreender o sentido da comunicação (como se fosse o receptor normal), mas também e principalmente desviar o olhar para outra significação, outra mensagem entrevista, através ou ao lado mensagem primeira. A leitura efetuada pelo analista de conteúdo das comunicações não é, ou não é unicamente, uma leitura - a letra - mas antes o realçar de um sentido que se encontra em segundo plano (Bardin, 1977: p. 41).

Dessa forma, através dos aportes metodológicos acima citados, o presente estudo se dispôs a compreender como o Conselho Municipal de Educação se relaciona com o Instituto Federal de Goiás, no município de Luziânia.

\subsection{Referencial Teórico da Pesquisa}

Ao longo do desenvolvimento desta investigação científica, buscou-se diálogo com diferentes autores a fim de fundamentar os conceitos estruturantes do estudo. Neste sentido as principais referências que ampararam tal exercício científico foram:

Em relação ao referencial da pesquisa, sobre estudo de caso e pesquisa qualitativa, busca-se aporte em André (2005), Ferreira (2002) e Gil (2002).

O aporte metodológico dialoga com os seguintes autores: Rêses (2015), Bardin (1977), Maanen (1979), Berg (1998) e Creswell (2010). 
No que se refere ao debate recente sobre políticas públicas, optou-se pelos estudos de Hofling (2001), Gramsci (1989), Marques (1997), Dowbor (1994), Raichelis (2006), Silva (1999), GOHN (2011), Telles (1994), Avritzer (1994) e Faleiros (1985).

Em relação ao debate sobre a interface entre política pública e política social, conceitos sobre Estado, Movimentos Sociais e Sociedade Civil, alguns autores contribuíram de forma significativa para essa pesquisa, dentre os quais destacamos: Aristóteles (2011), Hofling (2001), Marx (1986), Coutinho (1999), Iamamoto (2008), Ribeiro (1981), Bobbio (2001) e Gerschman (2004).

Sobre Democracia e Políticas Públicas, os principais autores utilizados foram: Moraes (2007), Abbagnano (2012), Silva (2007) e Muller (1998). A participação popular nos Conselhos é pesquisada principalmente pautada nas reflexões dos autores Dias \& Matos (2012) e Abbagnano (2012).

As Políticas Públicas de Educação foram baseadas nos textos da Constituição Federal do Brasil (1988), LDB (1996), França (2008), Paulo Freire (2011), Bressan (2001), Castell (2005), Alves (2012), Oliveira (2004), Morin (2012) e a Educação Profissional e Tecnológica é analisada sob os pontos de vistas de Cunha (2005), Cardozo (2010) e Pacheco (2008).

Nesta pesquisa, procurou-se estabelecer um diálogo com a produção científica acerca do objeto de estudo tendo como referenciais os autores Teixeira (2012) e Ribeiro (2011).

Teixeira (2012), em sua tese de doutorado, intitulada "Participação e controle democrático sobre o orçamento público em um contexto de crise do Capital”, discutiu a influência do controle democrático sobre o orçamento público das políticas sociais.

Ribeiro (2011) na tese de doutorado intitulada "Sujeitos e projetos em disputa na origem dos conselhos de políticas públicas" analisou o debate das origens históricas dos conselhos de políticas públicas através da trajetória de sujeitos, propostas e projetos em disputa na sociedade brasileira.

Sob esta perspectiva, os estudos de Figueiredo (2012), Garcia (2011) e Siqueira (2011) tem intrínseca relação com o objeto de pesquisa ora apresentado.

Figueiredo (2012) investigou a composição, natureza, representação e participação da sociedade civil nos conselhos de assistência social e suas implicações para o controle social nos municípios de pequeno porte no estado de Mato Grosso. 
Garcia (2011) analisou os desafios enfrentados pelos conselheiros do Conselho Municipal de Assistência Social de Franca/SP no processo de participação dos usuários na perspectiva da efetivação do Sistema Único de Assistência Social - SUAS.

Siqueira (2011) avaliou a atuação do Conselho Municipal de Assistência Social em Caxias (Maranhão) e as relações que o mesmo estabelece com as entidades privadas que integram a rede socioassistencial no município.

Os autores Souza (2006), Lavalle, Houtzager \& Castelo (2006) e Sipioni \& Silva (2013) também contribuíram substancialmente para melhor compreensão sobre democracia, participação popular e controle social.

Souza (2006), no artigo intitulado "Os Conselhos Municipais de Educação no Brasil: um balanço das referências nacionais (1996-2002) faz um recorte da produção científica brasileira em torno do eixo temático política, gestão e financiamento de Sistemas Municipais Públicos de Educação no Brasil, cobrindo o período de 1996 a 2002. Tal estudo evidenciou como se efetiva a participação popular e o controle social no universo destes espaços democráticos.

Lavalle, Houtzager \& Castelo (2006), no artigo científico "Representação política e organizações civis: novas instâncias de mediação e os desafios da legitimidade", destacam a emergência de formas de representação política realizada por organizações civis e as possíveis consequências para a ampliação da democracia.

Sipioni \& Silva (2013), no artigo científico intitulado "Reflexões e interpretações sobre a participação e a representação em conselhos gestores de políticas públicas", dissertam sobre a literatura recente acerca do tema da representação em conselhos gestores de políticas públicas buscando compreender diferenças conceituais entre democracia participativa e representativa, analisando como se consolida a participação em cada espaço pesquisado.

No caso particular de Luziânia - Goiás, onde se investiga a relação do Conselho Municipal de Educação e o Instituto Federal de Goiás, adotou-se a pesquisa empírica, desenvolvida a partir de entrevistas compostas por perguntas abertas, visando caracterizar a participação dos conselheiros e investigar se há ou não efetividade da função social do Conselho pesquisado e como se dá a sua relação com o IFG. A escolha pela entrevista individual aos conselheiros e ao diretor do IFG demonstrou-se a mais adequada a este estudo. A entrevista individual em profundidade requer informações detalhadas sobre circunstâncias particulares, trabalha na perspectiva da história de vida do participante da pesquisa, há facilidades de tempo e participação dos informantes (RÊSES, 2015). Este autor ressalta que a 
pesquisa com entrevistas consiste num processo social, interativo, tendo a relação dialógica como ferramenta de troca de informações e significados entre entrevistado e entrevistador.

Ao utilizar a pesquisa qualitativa, optou-se em enfatizar o conteúdo das falas dos entrevistados, que demonstraram nas entrevistas engajamento político e disponibilidade em exercer a função de controle social no âmbito do Conselho Municipal de Educação em Luziânia, Goiás.

As formas de divulgação da análise elencadas nessa pesquisa consistiram em tabelas, gráficos, indicadores e relatos. Segundo Maanen (1979), a expressão "pesquisa qualitativa" assume diferentes significados no campo das ciências sociais. Compreende um conjunto de diferentes técnicas interpretativas que visam a descrever e a decodificar os componentes de um sistema complexo de significados. Tem por objetivo traduzir e expressar o sentido dos fenômenos do mundo social. Trata-se, portanto, de reduzir a distância entre indicador e indicado, entre teoria e dados, entre contexto e ação (MAANEN, 1979, p. 520).

Em sua maioria, os estudos qualitativos são feitos no local de origem dos dados, não impedem o pesquisador de empregar a lógica do empirismo científico (adequada aos fenômenos claramente definidos), mas partem da suposição de que seja mais apropriado empregar a perspectiva da análise fenomenológica, quando se trata de fenômenos singulares e dotados de certo grau de ambiguidade.

Os dados foram coletados no período de 01 de março a 31 de julho de 2015, com o propósito de analisar o conteúdo das atas das reuniões plenárias do Conselho Municipal de Educação e as falas dos representantes do referido Conselho e do Instituto Federal de Goiás. Além disso, em busca de uma melhor compreensão do papel dos conselhos, foram objetos de análise algumas Leis e Resoluções com comparação de dados do IBGE, resgatando a história da Política Nacional de Educação - PNE e da Lei de Diretrizes e Bases da Educação - LDB.

O presente trabalho tem como limite de pesquisa os órgãos cadastrados no Conselho Municipal de Educação, incluindo o IFG, onde foram entrevistados membros do Conselho Municipal de Educação e representante do Instituto no município de Luziânia. Apesar de outros profissionais contribuírem para o funcionamento da rede municipal de controle social, aqueles que não possuem assento no Conselho de Educação não foram contemplados neste estudo. Algumas entrevistas foram gravadas e outras o entrevistado optou em responder, além da forma oral, também na forma escrita, por não se sentir à vontade com a utilização do aparelho de gravação. Destaca-se que tais fatos não interferiram na análise das falas e na transcrição das entrevistas. 
Vale ressaltar que o Instituto Federal de Goiás, mesmo sendo membro de um Conselho Municipal, é uma entidade federal, que serve de interlocutor entre as esferas (União, Estado e município) e de participação popular na cidade de Luziânia - GO.

\subsection{Objetivos, Problematização e Hipótese}

Para atingir os objetivos da pesquisa, procedeu-se à análise qualitativa das atas e demais documentos do Conselho Municipal de Educação, bem como entrevistas com o Diretor-Geral do IFG e com todos os representantes do Conselho, atuantes no período compreendido entre 15 de outubro de 2013 e 15 de abril de 2015, visando compreender a relação do Conselho Municipal de Educação com o Instituto Federal de Goiás.

Sob esta perspectiva, os principais objetivos elencados foram:

Geral: Analisar a participação do Instituto Federal de Goiás como contributo do cumprimento e efetividade da função social do Conselho Municipal de Educação em Luziânia $-\mathrm{GO}$.

Específicos: a) Avaliar como o Conselho Municipal de Educação vem cumprindo o seu papel social a partir da participação do IFG no seu quadro representativo;

b) Conhecer a história do município de Luziânia, relacionando-a com a composição do Conselho Municipal de Educação na atual gestão;

c) Desenvolver um plano de trabalho que caracterize um produto técnico Observatório da Educação - com ênfase na história da cidade de Luziânia e divulgação dos trabalhos do Conselho e do IFG.

A problematização consiste em entender: qual tem sido, efetivamente, a contribuição do Instituto Federal para que a função social do Conselho Municipal de Educação seja cumprido, na perspectiva democrática, contemplando a participação popular e o controle social?

No decorrer do processo investigativo sobre a relação do Conselho Municipal de Educação (CME) com o Instituto Federal de Goiás (IFG), analisou-se a hipótese que consiste em avaliar se a participação do Instituto Federal de Goiás no Conselho Municipal de Educação, em Luziânia - GO se expressa em protagonismo e empoderamento, enquanto contributos para a consolidação da função social do Conselho. 


\section{Capítulo II - Estado, Políticas Públicas e Controle Social}

\subsection{Breve Histórico das Políticas Públicas no Brasil}

As Políticas Públicas são, desde a Constituição de 1988, objeto de estudos e de atuação no campo do jurídico. Dentre os vários conceitos, podemos afirmar que Políticas Públicas, em linhas gerais, se constituem em programas e serviços governamentais e não governamentais, com a finalidade de consolidação dos direitos sociais.

Destarte, tais políticas nem sempre estiveram diretamente ligadas a este escopo da realidade apresentada. Nos anos que antecederam a década de 1980, sobretudo no Período Ditatorial (a partir de 1964), o viés era composto pelo discurso da eficiência e da eficácia, com prevalência clara dos interesses econômicos em detrimento dos reais interesses da população (HOFLING, 2001). Os conceitos de Estado e Políticas Públicas, apesar de serem distintos, dialogam com os autores pesquisados. Pode-se dizer que Estado é a organização política administrativa de uma sociedade e que Políticas Públicas são programas e serviços do governo nas diversas áreas setoriais e econômicas.

Ainda conforme Hofling (2001), apesar do discurso neoliberal sobre a falência do Estado, difundido pelos teóricos da globalização, o que se afirma é a centralidade do Estado, como peça chave na expansão das empresas multinacionais. Os Estados são estratégicos, tanto no estabelecimento de pactos comerciais quanto nos acordos de investimentos da proteção à produção em seu território, mediantes barreiras alfandegárias, na pesquisa e no desenvolvimento de novas tecnologias para subsídios de interesses do Capital. O resultado desse processo tem sido o agravamento da desigualdade social e o aprofundamento da exploração. Crescem os segmentos populacionais excluídos dos mercados, tendo em vista que não conseguem transformar suas necessidades sociais em demandas monetárias.

Vale destacar que tanto a figura de um Estado formalmente constituído, quanto à adoção de políticas públicas geram, em maior ou menor grau, a supremacia de classes dominantes sobre a coletividade, determinando rumos sociais, nem sempre acabam sendo respeitadas a representatividade ou a vontade da massa populacional.

O exercício do poder de uma classe ou classes sobre as demais, nas sociedades capitalistas - que é igualmente poder de Estado - ocorre pela combinação mais ou menos 
equilibrada da coerção e do consenso. O exercício deste poder é assegurado, por um lado, pela sociedade política (ou ditadura, ou aparelho coercitivo que assegura a conformidade das massas populares ao tipo de produção ou de economia em um momento determinado) e, por outro, pela sociedade civil - onde a hegemonia do grupo social sobre o conjunto da sociedade nacional é exercido através das organizações ditas privadas tais como as igrejas, os sindicatos e as escolas (GRAMSCI, 1989).

Para Gramsci (1989), a escola é a instituição que transmite os saberes acumulados de forma ideológica. A escola educa moral, científica e filosoficamente, tanto os futuros operários, quanto os futuros pequenos burgueses, além dos futuros burocratas e dirigentes intelectuais e ideológicos da classe dominante.

De acordo com Marx (1986, p. 94), a "sociedade civil abarca o conjunto das relações materiais dos indivíduos no interior de um determinado estágio de desenvolvimento das forças produtivas", ou seja, corresponde à estrutura econômica e social de certo período histórico. Em Gramsci, a "sociedade civil é a portadora material da figura social da hegemonia", concebida como "esfera de mediação entre a infraestrutura econômica e o Estado em sentido restrito" (COUTINHO, 1999, p. 121).

No que se refere às Políticas Públicas de Educação, Marques (1997) afirma que a literatura marxista enfoca o Estado e a questão das políticas públicas de maneira precisa. Da perspectiva do marxismo clássico, o Estado deve ser entendido como um órgão diretamente de classe. O estudo ora apresentado, simultaneamente, busca demonstrar a importância da inserção das políticas públicas sociais no âmbito do Estado Democrático de Direito e como tal movimento interfere no poder decisório e na tomada de decisões governamentais no que tange à efetivação das Políticas Públicas e como isso interfere na vida cotidiana das pessoas assistidas por tais ações governamentais.

Neste sentido, é viável a afirmativa de Dowbor (1994), que pontua a relevância necessária e estratégica do fortalecimento do poder local e da participação popular. $\mathrm{O}$ planejamento descentralizado, oportunizando a participação efetiva e genuína da comunidade constitui a materialização da oportunidade dos cidadãos se pronunciarem antes das decisões serem tomadas, em vez de se limitarem a protestar diante dos fatos consumados, decididos geralmente de maneira arbitrária, atendendo interesses de uma minoria (DOWBOR, 1994, p. 78). O mesmo autor defende ainda que "a participação popular ergue uma nova perspectiva de política pública em confronto com a tradição do caciquismo local e com o centralismo 
burocrático imposto pelos grandes grupos econômicos e políticos nacionais" (DOWBOR, 1994, p. 81).

Sob tal perspectiva, de acordo com Raichelis (2006), ampliou-se o debate sobre as políticas sociais, principalmente na década de 1980. O processo de redemocratização do Estado e de maior participação da sociedade brasileira, sobretudo na década de 90, introduz inflexões importantes, possibilitando o fortalecimento da ideia de constituição de espaços públicos, com mudanças no cenário e inserção de novos sujeitos sociais na construção da esfera pública, com participação ativa da sociedade civil no âmbito de tais políticas. A mesma defende que

a importância que vem sendo atribuída ao debate sobre a organização e gestão das políticas sociais pode ser apreendida por meio de diferentes ângulos de análise, mas certamente, relaciona-se às profundas transformações que se processam velozmente na sociedade capitalista contemporânea, e cujas interpretações desafiam intelectuais, pesquisadores, profissionais, gestores e todos os sujeitos investidos de algum nível de responsabilidade pública. (RAICHELIS, 2006).

Ainda conforme Raichelis (2006), as históricas relações entre Estado, mercado e sociedade civil, que consolidaram as diferentes formas de realização do Estado de Bem-Estar Social em várias partes do mundo, resultaram em conquistas sociais e democráticas, que buscaram compatibilizar as desigualdades sociais criadas pelo capitalismo com equidade e redistribuição da riqueza social produzida. Já em meados da década de 70 , esse modo de regulação social do sistema capitalista, que estruturou o chamado Welfare State, entrou em crise, colocando em xeque as bases históricas e as conquistas sociais consolidadas a partir da Segunda Grande Guerra (1939 a 1945), no contexto mundial que ficou conhecido como os "30 anos de ouro do capitalismo".

Já na concepção de Silva (1999),

as políticas públicas sociais, entendidas como a intervenção do Estado na formulação e implementação dos padrões de proteção social dos trabalhadores e da população como um todo, vêm sendo construída em favor de um movimento privatista alimentado pela doutrina neoliberal, em que as conquistas sociais são desmontadas para dar conta das exigências do mercado que se impõem como valor sagrado e força absoluta. De acordo com o meu ponto de vista e apoiado em algumas evidências quotidianas nacionais e internacionais, além do olhar dos estudiosos, argumento que as atuais políticas públicas implantadas, tanto nos países de capitalismo avançado como nos países de capitalismo periférico, por estarem ancoradas na concepção neoliberal, não são efetivamente políticas sociais. (SILVA, 1999, p. 79). 
No Brasil, o debate sobre as políticas sociais na perspectiva de sua redemocratização tem origem no cenário político dos anos 80, quando emergem vigorosamente as lutas contra a ditadura militar (1964 a 1985) e os esforços pela construção do Estado Democrático, envolvendo a participação efetiva da sociedade civil. (RAICHELIS, 2006).

A partir dos anos 80, registrou-se uma maior organização e participação dos movimentos sociais no processo de formulação e execução de políticas públicas. Os movimentos sociais, segundo Gohn (2011), são ações coletivas de caráter sociopolítico e cultural que viabilizam formas distintas da população se organizar e expressar suas demandas. $\mathrm{Na}$ ação concreta, essas formas adotam diferentes estratégias que variam da simples denúncia, passando geralmente por pressão direta, a exemplo de passeatas e mobilizações. $\mathrm{Na}$ atualidade, os movimentos sociais atuam por meio de redes sociais, locais, regionais, nacionais e internacionais ou transnacionais, tendo a internet como principal canal de comunicação, a exemplo do Facebook.

Telles (1994) discute os conceitos de cidadania e aponta como as possibilidades de práticas cidadãs podem se enraizar nas práticas sociais, numa perspectiva de direitos a ter direitos. Neste contexto, a autora afirma ainda que a sociedade é extremamente complexa, contraditória e atravessada por ambivalências diversificadas. Portanto, a sociedade civil pode ser compreendida como heterogênea, multifacetária e plural.

Dialogando com os textos de Gohn (2011), pode-se afirmar que os movimentos sociais são representados pela Sociedade Civil que, numa dinâmica sociocultural e econômica brasileira, a partir da década de 80 , vem contribuindo para que os espaços democráticos se consolidem, a exemplo dos Conselhos, proporcionando, apesar das contradições oriundas da relação entre Estado e o "mundo do trabalho", uma sociedade mais participativa e com perspectivas de maior justiça social.

Ainda de acordo com Gohn (2011), emergiram várias iniciativas de parceria entre a sociedade civil organizada e o poder público, impulsionadas por políticas estatais. Todos atuam em questões que dizem respeito à participação dos cidadãos na gestão dos negócios públicos.

Leonardo Avritzer (1994) pontua que os movimentos sociais constituem aquela parte da realidade social na qual as relações sociais ainda não estão cristalizadas em estruturas 
sociais, nas quais a ação é a portadora imediata da tessitura relacional da sociedade e do seu sentido.

De acordo com a autora Ilse Scherer-Warrenem seu artigo intitulado "Das mobilizações às redes de Movimentos Sociais”,

a realidade dos movimentos sociais é bastante dinâmica e nem sempre as teorizações têm acompanhado esse dinamismo. Com a globalização e a informatização da sociedade, os movimentos sociais em muitos países, inclusive no Brasil e na América Latina, tenderam a se diversificar e se complexificar. [...] Tal contexto exige nova compreensão acerca da nova configuração da sociedade civil organizada, explicitando os múltiplos tipos de ações coletivas na contemporaneidade. A partir desta compreensão, busca-se explorar a diversidade na formação da identidade dos sujeitos, a transversalidade nas demandas por direitos, as formas de ativismo e de empoderamento através de articulações em rede, e consequentemente, a participação política dos atores sociais neste processo (SCHERERWARREN, 2006, p. 109).

Já Faleiros (1985) defende que a força do movimento operário e dos movimentos populares, em sua relação dicotômica com as classes dominantes, determina a estratégia utilizada dos grupos e movimentos sociais e populares. O mesmo afirma que, se a conjuntura é favorável à mobilização popular e expansão das lutas, a estratégia pode ser mais ofensiva. Se o momento se apresenta desfavorável, é marcado por uma retração das forças populares, a estratégia é defensiva.

Portanto, as afirmativas de Faleiros (1985) reforçam a ideia de que o Estado fecha as portas da negociação frente às reivindicações e concessões pleiteadas pela classe trabalhadora, que não são favoráveis ao processo de acumulação capitalista com a qual a força estatal coaduna. Isso pode retirar a legitimidade do Estado no que tange ao discurso oficial sobre democracia e participação popular. Nesse sentido, a posição estatal que prioriza, claramente, a defesa de acumulação de capital, legitima a sobreposição da questão econômica em relação à questão social.

Neste contexto, o processo de democratização do país, após o período ditatorial (1964-1985), culminou na aprovação da Constituição Federal em 1988, no âmbito de um amplo processo de mobilização social, com uma verdadeira reforma no campo das políticas públicas. A promulgação da Carta Magna privilegiou a democratização dos processos decisórios e a descentralização das atividades de formulação e implementação das políticas públicas, que passaram a ser pensadas também na esfera municipal, enfatizando-se a participação popular e o controle social. Com vistas a concretizar a realização destas 
mudanças, houve o incentivo à criação de fóruns públicos de debate e busca de instrumentos aptos a incentivar a participação consciente e motivada dos cidadãos nos processos de formulação e implementação de políticas públicas, que originaram os Conselhos Municipais, atualmente disseminados na maioria das cidades brasileiras.

A municipalização vem se mostrando mais viável para organizar e planejar as ações do poder público. Devido à proximidade com a população, as elaborações de políticas públicas se tornam mais aptas atender à realidade local. De acordo com Jacobi (1999), a organização democrática do poder local assume cada vez mais um espaço central na agenda que contempla a necessária articulação não só entre atores, mas também entre políticas.

O cenário que se apresenta no Brasil, após a década de 1970, a partir do fortalecimento dos movimentos populares e diversas outras formas de organizações, criou novos espaços e uma nova forma de relacionamento da sociedade civil e Estado, fortalecendo a resistência popular e luta pelos direitos civis e sociais.

[...] a participação social se caracteriza como um importante instrumento de fortalecimento da sociedade civil, notadamente dos setores mais excluídos, na medida em que as superações das carências acumuladas dependem basicamente da interação entre agentes públicos e privados, no marco de arranjos socioinstitucionais estratégicos (JACOBI, 1999, p.37).

O poder local, a capacidade administrativa que tende a levar em consideração a presença da população que antes apenas aceitava passivamente as decisões tomadas no poder federal que não conseguia ter o conhecimento preciso da realidade local. Os municípios antes eram, portanto, obrigados a implantar serviços, planos e programas que desconheciam a estrutura social, econômica e cultural da população.

Afirma Dowbor (2008) que,

Com o volume de problemas que se apresenta, a administração municipal já não pode mais ser vista, portanto, como um nível de decisão que se limita à construção de praças, recolhimento de lixo e outras atividades de cosmética urbana. Trata-se de um eixo estratégico de transformação da forma como tomamos as decisões que concernem ao nosso desenvolvimento econômico e social, ao potencializarmos o papel articulador do conjunto das iniciativas e agentes econômicos e sociais que agem no território (DOWBOR, 2008).

Sob esta perspectiva, o estudo sobre a relação entre o Conselho Municipal de Educação e o Instituto Federal de Goiás aponta para a necessidade de maior compreensão da realidade analisada. Isto visa assegurar que elementos inerentes às práticas democráticas, com viés participativo e de controle social, permeiem a presente pesquisa, em que a inserção de 
representantes de Movimentos Sociais no âmbito do Conselho de Educação se faz imprescindível, neste processo, para efetivação da política pública no município de Luziânia Goiás.

\subsection{Política Pública, Política Social e Política: Um Debate Necessário}

Em um primeiro momento, serão abordados os principais aspectos atinentes às diferenças entre política, política pública e política social, perpassando o seu surgimento. Em seguida, será apresentado o desenvolvimento, na atualidade, das principais noções acerca dessas políticas.

A origem epistemológica da palavra política, do grego "politikós", está no adjetivo pólis, referente à cidade, ou seja, ao que é urbano, civil, público e social. Foi Aristóteles, contudo, um dos precursores da expansão do termo, graças à grande influência de sua obra denominada "Política", a qual objetivou dar as primeiras noções para a construção de uma sociedade minimamente estruturada em cima de regras e valores éticos. Para Aristóteles (2011), política é arte ou ciência de governo.

Ao longo do tempo, a palavra "política" sofreu variações conceituais, sendo definida como "a atividade ou conjunto de atividades que de alguma maneira têm como termo de referência a pólis, ou seja, o Estado" (HÖFLING, 2001). Atualmente, o conceito de política pode ser definido como forma de atividade ou práxis humana, o qual está intimamente ligado ao conceito de poder.

Nesta mesma linha de raciocínio, Ribeiro (1981) considera que o termo "política", em qualquer de seus usos, seja na linguagem comum ou na linguagem dos especialistas, refere-se ao "exercício de alguma forma de poder e, obviamente, às diversas consequências desse exercício. Ocorre que, naturalmente, todos os meios pelos quais se exerce o poder estão imiscuídos de complexidade, embora isto não esteja tão explícito num primeiro momento".

Dessa forma, as decisões políticas são produto, em sua maioria, de relações de poder, ou seja, envolvem, sumariamente, uma inter-relação entre a fonte de poder (que implementou a decisão) e os subordinados à força deste poder (aqueles que direta ou indiretamente serão afetados pela decisão).Contudo, a conceituação de política não se resume etimologicamente ao exercício de poder. O conceito ainda permanece vago, razão pela qual se 
faz necessário esclarecer o significado de poder, bem assim de suas implicações para com o campo da política e das políticas públicas.

Bobbio (2001) destaca, na filosofia política, o problema do poder sob dois aspectos principais, a partir dos quais se formam as teorias fundamentais substancialista e subjetivista. A teoria substancialista concebe o poder como algo que se possui e se utiliza como tantos outros bens. Assim, pode ser qualquer coisa (desde os meios naturais, como força, inteligência, quanto os adquiridos, como a riqueza) que possibilite alcançar aquilo que é o objeto do próprio desejo. Nesta corrente, destaca-se a interpretação substancialista de Hobbes. Já para os subjetivistas, como Locke, o poder não é o meio que serve para alcançar o objetivo, mas a capacidade de se obter determinados efeitos. Esta forma de compreender o poder é a utilizada pelos juristas para definir o direito subjetivo na medida em que ter um direito desta natureza é consequência da concessão do ordenamento jurídico do poder de produzir certos efeitos.

Complementando este conceito, define-se poder, numa perspectiva moderna, a partir da contribuição do sociólogo alemão Max Weber, como "a probabilidade de um ator social (a burocracia, por exemplo) levar adiante sua vontade, apesar das resistências que ela enfrenta, isto é, mesmo que esta seja em oposição à vontade do outro".

Este entendimento denota claramente que o tom conferido ao poder é de dominação. E o tipo de dominação que se destaca aqui é o baseado no poder organizacional da burocracia, usada como "instrumento de rotinização da vida humana". Assim, em função da máquina burocrática caracterizar-se pela impessoalidade, competência e hierarquia de cargos, a legitimação deste poder, denominado de legal-racional, deriva da confiança que a sociedade deposita no aparelho administrativo. Na definição de Bobbio (2001), poder significa a capacidade ou a possibilidade de agir, de produzir efeitos", envolvendo tanto indivíduos ou grupos de pessoas, quanto objetos ou fenômenos naturais. No entanto, a definição mais aceita para a ciência política é a de que "o poder é uma relação e esta relação ocorre entre pessoas".

Assim, na conjuntura das políticas públicas, a política pode ser entendida como um conjunto de procedimentos que expressam relações de poder e que se orienta à resolução de conflitos no que se refere aos bens públicos. Complementando, a política é a forma de resolução não violenta de conflitos, ou seja, sua função principal é resolver as dissensões sem 
que isto implique na destruição dos grupos em desacordo. Ela tem a finalidade de desarmar o conflito e transformá-lo em uma alternativa não destrutiva para a coletividade em geral.

Outra diferenciação que deve ser feita diz respeito às noções de política pública e política social. Defende-se ainda que as políticas sociais fazem parte de um subconjunto pertencente a um conjunto maior que se denomina de políticas públicas. Nas palavras da própria autora, "toda política social é uma política pública, mas nem toda a política pública é uma política social".

Nota-se que a expressão política pública, além de ser composta pelo termo "política" - e de todos os significados inerentes a este conceito - também é formada pela palavra "pública", que igualmente é carregada de sentido e utilizada em diversas acepções. Assim, o conceito de política pública também leva, invariavelmente, ao domínio do que é público e de todo o seu universo, ou seja, remete às questões coletivas. Numa análise preliminar, pode-se dizer que o termo difere do que é considerado privado e individual para se focar nas questões que dizem respeito a uma coletividade.

Num segundo plano, o público difere-se do estatal, não correspondendo a um sinônimo deste. O público abarca uma perspectiva mais ampla, que se divide em estatal e não estatal. A atuação estatal deve estar voltada essencialmente ao que é público. Contudo, existem instituições e organizações da sociedade que manifestamente também possuem objetivos públicos e que, em decorrência disso, recebem a denominação de públicas não estatais.

Conforme Iamamoto (2008), na análise da importância da efetivação das políticas públicas, depara-se com um cenário atual de acentuação do papel que cumpre o Estado, que se propõe historicamente a sustentar a estrutura de classes e as relações de produção. O marxismo clássico já estabelecia as funções que pertencem ao domínio do Estado: criar as condições gerais da produção, que não podem ser asseguradas pelas atividades privadas dos grupos dominantes; controlar as ameaças das classes dominadas ou frações das classes dominantes, através de seu braço repressivo (exército, polícia, sistema judiciário e penitenciário); e integrar as classes dominantes, garantindo a difusão de sua ideologia para ao conjunto da sociedade.

Desta afirmativa, percebe-se que as políticas externa, econômica e administrativa são políticas públicas relevantes porque dizem respeito à ação do Estado, mas não se 
relacionam às políticas sociais, embora, muitas vezes, o sucesso de uma política social seja consequência da eficácia das políticas públicas mais abrangentes.

No entendimento de Höfling, (2001), as políticas sociais têm intrínseca ligação com o modelo de garantias sociais, adotado por determinado Estado. Em suas palavras,

[...] políticas sociais se referem a ações que determinam o padrão de proteção social implementado pelo Estado, voltadas, em princípio, para a redistribuição dos benefícios sociais visando a diminuição das desigualdades estruturais produzidas pelo desenvolvimento socioeconômico. As políticas sociais têm suas raízes nos movimentos populares do século XIX, voltadas aos conflitos surgidos entre capital e trabalho, no desenvolvimento das primeiras revoluções industriais (HÖFLING, 2001).

Óbvio que, quando o foco está nas políticas sociais (habitualmente entendidas como as de saúde, previdência, educação, saneamento, habitação, entre outras), os fatores envolvidos para avaliar o êxito ou o fracasso dessas políticas são complexos, diversificados e requerem maior concentração de esforços. Esclarecidos estes aspectos iniciais, passa-se à análise do surgimento e desenvolvimento das políticas públicas, a começar por sua evolução no cenário internacional e posterior incorporação pela esfera nacional.

Originariamente, como já demonstrado, as políticas públicas têm sua raiz na palavra "política", sendo Aristóteles o primeiro responsável pela disseminação do vocábulo, que expressa, de uma forma geral, um conjunto de relações de poder com vistas à resolução de conflitos de forma não violenta. No entanto, as políticas públicas, como área específica da ciência política, começaram a ser estudadas apenas em meados do século XX, quando a complexidade da sociedade começava a exigir ações governamentais concatenadas, tanto nos setores econômico-financeiro quanto social.

Assim foi que, nos Estados Unidos, no início dos anos 50, essa vertente da ciência política começou a se instituir sob o rótulo de "policyscience", em especial com a obra de Harodl Dwight Lasswel, enquanto que na Europa, mais precisamente na Alemanha, a preocupação com certos campos da política só aparece no início dos anos 70, quando, graças ao movimento social democrata, as políticas setoriais foram significativamente expandidas.

Já no Brasil, as políticas públicas foram percebidas, num primeiro momento, com certo descrédito, em vista da ação estatal pejorativa. No período de transição para o século XXI, a imagem que subiste a respeito é uma imagem negativa, influenciada pela perspectiva minimalista. Apesar de circular uma nova perspectiva acerca do consenso antiestatal nas nações desenvolvidas e mesmo no campo das agências financeiras que determinam parte 
considerável das políticas públicas nos países em desenvolvimento, no Brasil prevalece uma atmosfera de receio com relação ao setor estatal, que sequer leva em consideração a capacidade do Estado em promover o desenvolvimento.

Outro fator a ser considerado é o descrédito da população em relação ao Estado e à administração pública, principalmente no que diz respeito à atuação estatal, às políticas públicas e aos políticos em geral. Mesmo após o processo de democratização iniciado nos anos 80, a disseminação de práticas clientelistas, marcadas pela corrupção e a maior publicidade destes fenômenos, provenientes do próprio processo, somaram-se à ideologia neoliberal que estimula a redução radical da ação do Estado. Tudo isso contribuiu, sobremaneira, para agravar a confiança que os cidadãos depositam na ação governamental e na administração pública em todas as esferas do governo.

Há, de uma forma geral, uma "ausência de perspectivas", que conduz ao pensamento de que não apenas o Estado é ineficaz por natureza, como também na relação entre Estado e sociedade no Brasil, tudo parece ter permanecido igual e jamais mudará, tendo em vista que os vícios desta relação são intrínsecos ao Estado. Esta visão consagra o entendimento de que não há solução para o Estado além de reduzi-lo ao status de Estado mínimo.

De acordo com Farah (2000), historicamente, as políticas públicas promovidas pelo Estado brasileiro vêm perpassando por uma trajetória que demonstra sua evolução no tempo, marcadas pela centralização decisória e financeira na esfera federal. A descentralização incumbe aos municípios, quando participantes de uma política específica, a tarefa de executar as políticas formuladas centralmente. Nesse sistema, tende-se a romper a relação histórica de cunho clientelista entre governos estaduais, municipais e federais, baseada na troca de favores.

Ainda conforme a autora, outra característica das políticas públicas antes da promulgação da Constituição Federal de 1988 era a fragmentação institucional, marcada por ações desintegradas, desconectadas, sem coordenação na ação dos diversos órgãos. A setorialidade, também se apresenta como um traço deste período, porquanto cada política e cada setor do serviço público eram ofertados de forma autônoma, sem a necessária articulação entre as diversas áreas, sendo esta peculiaridade responsável pela perda dos potenciais efeitos positivos das ações. Destarte, a exclusão da sociedade civil do processo de formulação e 
implementação das políticas públicas corroborou com a relação restrita entre Estado e sociedade, culminando em ações clientelistas, corporativistas e de insulamento burocrático.

O desenvolvimento de um "padrão não democrático de articulação entre Estado e sociedade", marcado pela ausência de meios de controle das ações estatais e por um modelo de gestão hierarquizado das políticas, contribuiu apenas para reforçar a exclusão de vastos segmentos da sociedade ao acesso a bens e serviços públicos.

Para Rocha (2011),

A sociedade civil sempre será pressionada por "externalidades", ou efeitos não pretendidos, de processos políticos, socioeconômicos (desemprego, criminalidade e supremacia do mercado) e tecnológicos (com a televisão e Internet, por exemplo, afastando as pessoas do convívio no espaço público) ou por fatores intencionais, como a ação do Estado e/ou da sociedade antiliberal. Exemplo disso é que a notável mobilização de diversos setores da sociedade civil brasileira, nos anos 1980, refluiu nas décadas seguinte. (ROCHA, 2011.p.175).

Assim, embora houvesse em todo o mundo - já no final dos anos 1950, especialmente nos países do pós-guerra - a proposta de um envolvimento da sociedade civil na busca de soluções para as questões sociais, no Brasil prevaleceu, até os anos 1980, como referência à formulação de políticas públicas, o modelo centrado na provisão estatal.

Diante desse quadro, fez-se necessário uma verdadeira reforma nas políticas públicas, que foi estimulada pelo processo de democratização experimentado pelo país e concretizado na Constituição Federal de 1988. Com respeito a essa nova perspectiva, que introduziu uma nova relação entre Estado e sociedade, marcada por um perfil cidadão da sociedade civil, Gerschman assevera que:

[...] foi precisamente a ideia de cidadania como motor dos movimentos sociais que promoveu a formação de uma identidade entre portadores de "iguais" carências e que conduziu à inclusão dos direitos sociais nos direitos de cidadania. As políticas sociais, adquirindo o sentido de instrumento da justiça social, passaram a ser o fio transmissor entre a sociedade e um Estado omisso no período. A interdição do Estado torna-se insuficiente para controlar a ação coletiva destes novos atores, passando os movimentos sociais a se articular enquanto organismos políticos de representação da sociedade. A sua contrapartida, no exercício da política governamental já na democracia, os Conselhos Societários, se constituíram em tema central das políticas sociais e atravessaram a discussão política até o fim da década de 80 (GERSCHMAN, 2004). 
A partir dessa nova perspectiva, visualiza-se a relevância da construção de estruturas e implementação de mecanismos democráticos que incluam o cidadão nos processos de tomada de decisão, assegurando assim maior efetividade das Políticas Públicas.

\subsection{Democracia e Políticas Públicas}

Com a promulgação da Constituição Federal de 1988, adota-se no Brasil o conceito de Estado Democrático de Direito. Para Moraes (2007), tal expressão significa que a instituição enquanto país deverá ser regida pelo Direito na sua forma mais ampla, garantindo pressupostos definidos pela Organização das Nações Unidas (ONU), a exemplo dos direitos e garantias fundamentais, além das normas democráticas, como eleições livres e periódicas válidas e convalidadas pelo povo.

Para tanto, o texto constitucional trouxe, logo em seu art. $1^{\circ}$, a garantia do Estado Democrático de Direito afirmando que "Todo o poder emana do povo, que o exerce por meio de representantes eleitos ou diretamente, nos termos desta Constituição". Visto isso, etimologicamente o termo democracia origina-se do grego dêmos que em sua origem significa povo, acrescido do termo kratía, que significa força, poder: sendo a democracia o poder do povo. Para Abbagnano (2012, p. 277), o termo democracia "adquiriu hoje uma dimensão que ultrapassa o significado específico de 'forma de governo' (governo do povo, pelo povo e para o povo) para indicar um modo de ser e de pensar".

O Estado Democrático de Direito envolve, obrigatoriamente, a soberania popular, conforme expõe José Afonso da Silva,

[,,,] o Estado Democrático se funda no princípio da soberania popular que impõe a participação efetiva e operante do povo na coisa pública, participação que não se exaure, como veremos, na simples formação das instituições representativas, que constituem um estágio da evolução do Estado Democrático, mas não o seu completo desenvolvimento (SILVA, 2007, p. 66).

Müller defende que:

A ideia fundamental da democracia é a determinação normativa de um tipo de convívio de um povo pelo mesmo povo. Já que não se pode ter o autogoverno na prática quase inexequível, pretende-se ter ao menos a autocodificação das prescrições vigentes com base na livre competição entre opiniões e interesses, com alternativas manuseáveis e possibilidades eficazes de sancionamento político (MÜLLER, 1998, p. 57). 
Tais afirmativas corroboram com a concepção de que o Estado Democrático de Direito deve ser transformador da realidade, proporcionando uma vida digna ao ser humano, perpassando tanto os aspectos formais quanto os sociais. O Estado tem o papel, enquanto entidade política, garantidor de tal democracia, utilizando-sedo seu poder soberano para fomentar a participação, tanto estatal quanto social em todos os segmentos da sociedade, de criar novas políticas públicas e reforçar as já existentes.

Assim, o Estado tem, necessariamente, o papel de instituidor de políticas públicas. A necessidade social de evolução através do desenvolvimento de ações públicas é latente, demandando do Estado, cada vez mais, uma postura proativa frente a essas demandas, configurando assim um governo popular intervencionista. Para avançar na compreensão do papel do Estado, é necessário compreender conceitualmente algumas referências para o nosso estudo:

- Política é uma ação humana - possui uma intenção e uma intencionalidade. Neste sentido, uma das condições fundamentais no próprio ser humano é agir intencionalmente, ou seja, politicamente - ao contrário, sua conduta se aproximaria dos animais, ou seja, ação instintiva sem uma intencionalidade;

- Política é uma condição humana - para alguns autores a política muito mais que uma ação humana, é a sua própria natureza, ou seja, o que define o ser humano como tal é a sua condição política;

- Política é uma ação transformadora - os serem humanos ao agirem politicamente transformam sua realidade. Estas transformações não são aleatórias ou instintivas como a transformação operada por outros animais na natureza, são intencionais. $O$ homem ao agir intencionalmente transforma a sua realidade politicamente;

- Política é uma ação coletiva - a política é uma ação intencional e transformadora, porém, o homem não transforma a realidade sozinho, ele a transforma junto a outros homens por meio das interações sociais - portanto a política é sempre uma ação 
coletiva - não existe política do "eu sozinho" - isto seria o mesmo que egocentrismo, um estágio de distúrbio de personalidade e não ação social. Para que empreendamos uma ação política é necessário sair do mundo particular e egocêntrico do sujeito - para o mundo das representações sociais coletivas.

\subsection{Participação Popular e Controle Social: O Papel dos Conselhos}

Pode-se afirmar que a Constituição de 1988 marcou o fim do padrão de planejamento tecnocrático e incorporou as intenções redistributivas. Inicialmente, a Constituição Cidadã propiciou a criação de instrumentos de promoção da descentralização administrativa e a redistribuição de recursos tributários, dando melhores condições para a atuação dos Estados e municípios em seus respectivos territórios.

Ressalta-se que os Conselhos Municipais de construção e deliberação de Políticas Públicas são órgãos coletivos, com participação do poder público e da sociedade civil na elaboração, execução e fiscalização das políticas municipais. Os Conselhos, segundo o Portal da Transparência do Governo Federal, constituem "espaços públicos de composição plural e paritária entre Estado e Sociedade Civil, de natureza deliberativa, cuja função é formular e controlar a execução de políticas públicas setoriais". Possuem caráter deliberativo, portanto, não executam diretamente as políticas (DIAS e MATOS, 2012, p. 165).

No intuito de maior compreensão sobre os Conselhos Setoriais, acredita-se que é fundamental a compreensão conceitual e histórica sobre controle social. Conforme Raichelis (2006), pode-se considerar como controle social a implicação do acesso aos processos que informam decisões da sociedade política, viabilizando a participação da sociedade civil organizada na formulação e na revisão das regras que conduzem as negociações e arbitragens sobre os interesses em jogo, além da fiscalização daquelas decisões, segundo critérios pactuados.

Bravo e Correia (2012) por sua vez defendem que a expressão controle social no Brasil tem seu surgimento na década de 1990 e que tal expressão tem sido utilizada como sinônimo de controle da sociedade civil sobre as ações do Estado, especificamente no campo das políticas sociais. E que a utilização do termo com este sentido é fruto da conjuntura das 
lutas políticas no processo de redemocratização do país frente ao Estado autoritário, implantado a partir da Ditadura Militar. (BRAVO; CORREIA, 2012).

A discussão do controle social na contemporaneidade busca inverter a lógica do período ditatorial, onde o Estado controlava todas as ações da sociedade civil, coibindo manifestações estudantis, artísticas, culturais, trabalhistas e sindicais. (BRAVO; CORREIA, 2012). Como limites e possibilidades da efetivação do controle social, é necessário à compreensão da diferença conjuntural do momento que os mecanismos de controle social foram propostos do momento que foram implementados. Bravo (2006) destaca que a concepção entre Estado e sociedade civil, contextualizado na década de 1990 é reflexo do processo de lutas sociais em torno do direito às políticas sociais.

Por outro lado, Bravo e Correia (2012) afirmam que a partir do ideário neoliberal, surge a proposta de contrarreforma do Estado brasileiro, a qual a sociedade é convocada a ser parceira com o objetivo de contribuir financeiramente com os custos dos serviços prestados. O que se propõe é a desresponsabilização do Estado com a proteção social, justificada pela necessidade de "encontrar soluções inovadoras, que envolvam as empresas, os sindicatos, as famílias e os grupos comunitários" (Banco Mundial, 1997, p. 6). Desta forma, as organizações da sociedade civil são convocadas para substituir o Estado.

Sob esta perspectiva, vale ressaltar que no Brasil, após a institucionalização dos mecanismos de controle social sobre as políticas públicas e sobre os recursos a elas destinados, têm-se como desafio que esses não se tornem mecanismos de formação de "consentimento ativo" das classes subalternas em torno da conservação das relações vigentes de domínio da classe dominante. O controle social das classes subalternas sobre as ações do Estado e sobre o destino dos recursos públicos torna-se importante na realidade brasileira para que se criem resistências à redução das políticas sociais, à sua privatização e mercantilização (Correia, 2005).

Nestes últimos anos, temos avançado na conquista de participação por meio de vários Conselhos. A Secretaria Geral da Presidência da República e a Secretaria Nacional de Articulação Social realizaram, em 2010, o levantamento dos Conselhos Nacionais, identificando a existência de 34 Conselhos, com seus respectivos anos de criação: 
- Conselho Curador do FGTS (1989);

- Conselho da Transparência Pública e Combate à Corrupção (2003);

- Conselho das Cidades (2012);

- Conselho dos Direitos Humanos (2014);

- Conselho de Desenvolvimento Econômico e Social (2003);

- Conselho Nacional de Agricultura e Pesca (2004);

- Conselho Nacional de Assistência Social (1993);

- Conselho Nacional de Ciência e Tecnologia (1996);

- Conselho Nacional de Combate à Discriminação (2010);

- Conselho Nacional de Defesa Civil (2012);

- Conselho Nacional de Desenvolvimento Rural Sustentável (2003);

- Conselho Nacional de Economia Solidária (2003);

- Conselho Nacional de Educação (1995);

- Conselho Nacional de Imigração (1980);

- Conselho Nacional de Juventude (2005);

- Conselho Nacional de Política Criminal e Penitenciária (1984);

- Conselho Nacional de Política Cultural (2005);

- Conselho Nacional de Políticas sobre Drogas (2006);

- Conselho Nacional de Previdência Social (1991);

- Conselho Nacional de Promoção da Igualdade Racial (2003);

- Conselho Nacional de Recursos Hídricos (2000);

- Conselho Nacional de Saúde (1990);

- Conselho Nacional de Segurança Alimentar e Nutricional (2006);

- Conselho Nacional de Segurança Pública (2003);

- Conselho Nacional de Turismo (2007);

- Conselho Nacional do Esporte (2002);

- Conselho Nacional do Meio Ambiente (1981);

- Conselho Nacional dos Direitos da Criança e do Adolescente (1991);

- Conselho Nacional dos Direitos da Mulher (1985);

- Conselho Nacional das Pessoas com Deficiência (2003);

- Conselho Nacional dos Direitos do Idoso (1994); 
- Comissão Nacional de Desenvolvimento Sustentável dos Povos e Comunidades Tradicionais (2004);

- Comissão Nacional de Políticas Indigenista (2006);

- Conselho Brasileiro do MERCOSUL Social e Participativo (2008).

Neste contexto, a descentralização é o mecanismo que implica a transferência efetiva de poder decisório para os agentes locais da administração municipal. Significa que os órgãos locais têm autonomia, nos limites estabelecidos, para formular políticas, estabelecer prioridades e planejar o atendimento das demandas.

Por fim, a participação popular ficou garantida no texto constitucional, por meio da possibilidade de instituir mecanismos para ampliar a inclusão de novos grupos sociais no planejamento e na defesa dos seus interesses. A Carta Magna abriu caminho para uma maior descentralização e democratização da gestão pública, de modo que o país adentrou na década de 1990 sob seus efeitos, mas ainda sem a definição de um projeto nacional de desenvolvimento e, por consequência, sem projetos e políticas públicas mais abrangentes e inclusivas.

Num estudo sobre os Conselhos Municipais em pequenos municípios brasileiros, Dombrowski (2008) afirma que é necessário olhar para os pequenos e médios municípios, pois em torno de 95\% dos municípios brasileiros, ou seja, 5.307 de um total de 5.565, possuem menos de 100 mil habitantes, e esses mesmos municípios abrigam quase a metade $49 \%$ - da população do país.

Por outro lado, os municípios médios - de acordo com o IBGE, aqueles que possuem população entre 100.000 e 500.000 habitantes - representam uma grande parte das cidades brasileiras, onde vivem $25,5 \%$ da população. Esta é a segunda faixa populacional por tamanho de município, atrás apenas dos municípios com mais de 500.000 habitantes (IBGE, 2010).

Se os conselhos municipais constituem uma inovação importante na política e na organização institucional Brasileira- e é amplamente reconhecida a importância dos conselhos - devemos analisar sua dinâmica e funcionamento nesses pequenos e médios municípios, de modo a evitar a exclusão da absoluta maioria das instituições e da população do país. 
Para o autor,

Não resta dúvida de que a década de 1990 foi marcada pela institucionalização dos conselhos municipais e que isso ocorreu como consequência da vigência da nova Constituição. Como já foi observado, os conselhos transformaram-se no formato institucional assumido por dispositivos presentes no texto da carta de 1988 que estabeleciam a participação da sociedade na gestão e controle das políticas públicas em diversas áreas fundamentais como saúde, assistência social e educação (DOMBROWSKI, 2008. P. 275).

Dombrowski (2008) esclarece que o reconhecimento da relevância e do impacto dos conselhos no período imediatamente seguinte à promulgação da Constituição não pode induzir conclusões apressadas. Os conselhos não são apenas influência de dispositivos constitucionais, eles decorrem de impulsos participativos presentes na sociedade brasileira antes de e durante o processo constituinte. Por outro lado, mesmo ocorrendo em meio a um processo de descentralização que ganhou destaque no decorrer de uma agenda neoliberal de reformas do Estado, que propõe a transferência de encargos da esfera federal para as esferas estadual e municipal, como também a desengajamento ou desresponsabilização do Estado, transferindo parte de suas obrigações para a sociedade civil; esses conselhos desempenham um papel fundamental no controle social de políticas públicas.

No que tange à amplitude das políticas públicas, os sistemas de atendimento aos cidadãos servem para que suas reclamações e solicitações de serviços públicos sejam prontamente atendidas. Um bom mecanismo de comunicação entre o poder público e a população é a Ouvidoria Pública, que consiste numa instituição que auxilia o cidadão em suas relações com o Estado, funcionando como uma crítica interna da administração pública, sob a ótica do cidadão. Diante do exposto, facilitar o acesso dos cidadãos e das entidades da sociedade civil aos dados e às informações de seu interesse nos órgãos públicos é fundamental para incrementar o processo de democratização da gestão pública.

Segundo Dias e Matos (2012), os Conselhos constituem canais de participação e representação das organizações sociais na gestão de políticas públicas específicas. Obrigatórios por lei federal em diversos setores (saúde, educação, criança e adolescente, assistência social e trabalho), os Conselhos se diferenciam de acordo com o Município. As principais variáveis se materializam pelo poder de decisão, deliberativo ou consultivo; pelos critérios de representação dos diferentes segmentos sociais, amplos ou restritos; e também pela dinâmica e pelas condições de seu funcionamento, ou seja, os instrumentos e a infraestrutura à sua disposição. 
Afirma-se que os Conselhos cumprem o papel de institucionalizar a participação da sociedade civil nos processos de formulação, implementação e avaliação da política sem, no entanto, substituírem o papel do gestor, a quem compete a implementação das políticas públicas. São canais de participação geralmente constituídos, discutem projetos, se tornam públicos, deliberam os temas relacionados, estabelecem acordos e alianças, explicitam conflitos, ou seja, atuam em espaços que permitem a negociação e a construção de consensos que viabilizam a implantação das políticas públicas. Para Dias e Matos (2012), os principais modelos de Conselhos são:

- Consultivo - aquele em que seus integrantes têm o papel apenas de estudar e indicar ações políticas sobre a sua área de atuação;

- Deliberativo - aquele que efetivamente tem o poder de decidir sobre a implantação de políticas e/ou a administração de recursos relativos à sua área de atuação;

- Fiscalizador - aquele que fiscaliza a implementação e o funcionamento de políticas e/ou a administração de recursos relativos à sua área de atuação;

- Normativo - aquele que estabelece normas e diretrizes para as políticas e/ou a administração de recursos relativos à sua área de atuação; e

- Paritário - órgão que apresenta um número igual de representantes da sociedade civil e do setor governamental.

Vale ressaltar que os modelos descritos não se autoexcluem, podendo ser conjuminados entre si. Neste sentido, o papel do Estado, a efetivação das políticas sociais públicas e o aprimoramento dos espaços de participação popular e controle social se tornam cada vez mais necessários, nestes tempos de barbárie e de mudanças. Uma realidade, cada vez mais complexa requer a criação e proposição de mecanismos de agenda, implementação, planejamento e avaliação das políticas públicas.

As políticas públicas de educação têm um papel importante na formação do cidadão, no fomento à participação da sociedade civil nos processos decisórios, pois essa política pública contribui para o desenvolvimento crítico da sociedade, exercendo, a partir desta, maior interlocução entre as demais políticas públicas, buscando maior efetividade e otimização de recursos públicos investidos na prestação de serviços à população. 


\subsection{Políticas Públicas de Educação no Brasil}

A Lei de Diretrizes e Bases, Lei 9.394, de 20 de dezembro de 1996 estabelece em seu primeiro artigo: abrangência dos processos formativos que se desencadeiam na vida familiar, na convivência humana, no trabalho, nas instituições de ensino e pesquisa, nos movimentos sociais e organizações da sociedade civil e nas manifestações culturais. Destacase ainda que a educação escolar deva vincular-se ao mundo do trabalho e cotidiano, pautado na cidadania.

A Educação enquanto política pública é organizada para atender ao direito social de toda pessoa, direitos esses expressos na Constituição Federal de 1988, na Lei de Diretrizes e Bases da Educação Nacional (LDBEN) e no Estatuto da Criança e do Adolescente (ECA), Lei 8069 de 13 de julho de 1990, destacando o direito à educação enquanto acesso e permanência na escola, tendo como finalidade a formação do sujeito para a cidadania. Para a implementação dessa política é necessário um conjunto de profissionais que atue em diferentes áreas e esferas com objetivos comuns, ou seja, a garantia de acesso e permanência dos alunos a uma escola de qualidade.
A escola pública, seus profissionais e alunos se encontram inseridos num contexto mais amplo, que vai além dos muros escolares e, sendo assim, o processo educativo deve considerar além do caráter multidisciplinar necessário e presente na educação formal, o caráter interdisciplinar que possibilita o desenvolvimento do olhar profissional mais ampliado, capacitado e aprimorado para apreender as diferentes questões e nuances presentes na realidade. (FRANÇA, 2006, apud Plano de ação 2008, p. 7)

A Política de Educação está pautada numa proposta que visa contribuir para a emancipação e cidadania, visando avaliar os impactos dos serviços prestados à comunidade, avaliando as políticas locais e instrumentais utilizados para promover maior justiça social.

Desde a sua promulgação, em 20 de dezembro de 1996, a Lei de Diretrizes e Bases da Educação Nacional vem redesenhando o Sistema Educacional em todos os níveis: da creche, desde então, incorporada aos sistemas de ensino, às universidades, além de todas as outras modalidades de ensino, incluindo a educação especial, profissional, indígena, no campo e ensino a distância" (BRASIL, 2010).

A LDB oferece-nos um campo de atenção às demandas da classe trabalhadora, tão amplo e abundante das expressões da questão social. É preciso compreender que a luta não é pelo espaço escolar, mas pelo campo da educação, como via de formação de sujeitos e de efetivação de direitos. 
A escola é: o lugar onde se faz amigos, não se trata só de prédios, salas, quadros, programas, horários, conceitos... Escola é, sobretudo, gente que trabalha, que estuda, que se alegra, se conhece, se estima: Coordenador é gente, o professor é gente, o aluno é gente, cada funcionário é gente (FREIRE, 2011).

Como estratégias para a efetivação das políticas públicas, busca-se uma maior interlocução entre Estado, Mercado e Sociedade Civil. Tal perspectiva aponta para uma maior interação entre as políticas públicas, destacando a Educação por meio da representatividade das instituições do Estado e da sociedade civil nos Conselhos Municipais, Estaduais e Nacionais.

Os altos níveis de pobreza e miséria que atingem a população brasileira se expressam das mais diferentes formas. $\mathrm{O}$ processo educacional não está alheio a isso, ou seja, o sistema de ensino também se constitui em um espaço de concretização dos problemas sociais (BRESSAN, 2001, p. 11).

A participação popular vem assegurando o controle social destas políticas públicas através de Conferências efetuadas em todas as esferas de governo, dentre outros fóruns pautados na participação dos diversos segmentos sociais e populares, apesar das contradições ainda vigentes no cenário brasileiro.

De acordo com o Observatório do PNE (2015), o Plano Nacional de Educação, sancionado pela Presidência da República, em junho de 2014, tem vigência de 10 anos, o que pode parecer prazo razoável para colocar em prática medidas que permitam alcançar as metas.

Porém, há muito a fazer desde já, pois existem metas e estratégias que têm como prazo 2015. Para começar, estados e municípios devem elaborar ou adequar os planos de Educação locais à luz de diretrizes, metas e estratégias previstas no PNE até junho, um ano após a sanção do plano.

A formulação dos planos municipais e estaduais deve envolver não apenas o Poder Executivo, mas também a comunidade Escolar de forma mais ampla, em um processo participativo, que culmina na aprovação pelo Legislativo e a volta para sanção pelo Executivo. O PNE é uma lei ordinária com vigência de dez anos a partir de 26/06/2014, prevista no artigo 214 da Constituição Federal. Ele estabelece diretrizes, metas e estratégias de concretização no campo da Educação. Municípios e unidades da federação devem ter seus planos de Educação aprovados em consonância com o referido Plano Nacional de Educação.

A meta que trata do analfabetismo prevê que a taxa de Alfabetização da população com 15 anos ou mais atinja 93,5\% em 2015. Isso significa aumentar a taxa de jovens e adultos 
alfabetizados em dois pontos percentuais, retomando o crescimento do indicador, praticamente estagnado desde 2011. Neste ano, será preciso também garantir a política nacional de formação dos profissionais da Educação, em regime de colaboração entre a união, os estados e os municípios, que assegure que todos os professores da Educação básica tenham curso superior, e os docentes dos anos finais dos ensinos fundamental e médio tenham licenciatura na área de conhecimento em que atuam. Em 2013, o percentual de professores da Educação básica com curso superior era de $75 \%$, sendo que com licenciatura na área em que atuam apenas 33\% dos professores dos últimos anos do Ensino fundamental e $48 \%$ dos docentes do Ensino médio (PNE, 2015).

É papel do Ministério da Educação (MEC), também neste ano, constituir fórum permanente para acompanhamento do valor do piso salarial nacional para os profissionais do magistério público da Educação básica. Até junho de 2016, será preciso garantir o plano de carreira para os profissionais da Educação pública de todos os sistemas de ensino e passar a realizar o censo anual dos profissionais da Educação básica, e não apenas os do magistério. No prazo de um ano, após o PNE entrar em vigor (junho de 2015), também deve ser aprovada a Lei de Responsabilidade Educacional, ou seja, ferramenta fundamental na construção da governança da Educação e por meio da qual deverá ficar claro que não são admissíveis retrocessos nos indicadores educacionais. A universalização da Pré-Escola deverá ser realidade nos municípios em 2016, conforme estipulado na primeira meta do PNE. Para tanto, as condições de infraestrutura e recursos humanos deverão estar contempladas em 2015. Os gestores que não iniciaram ainda os processos necessários dificilmente conseguirão cumprir o prazo, que vale também para a implementação da avaliação da Educação infantil que siga parâmetros nacionais, exigindo, portanto, enorme esforço de articulação dos entes da Federação e demais partes interessadas por parte do MEC (PNE, 2015).

Segundo o Plano Nacional de Educação, todos os jovens de 15 a 17 anos também devem, obrigatoriamente, estar na escola a partir de 2016. Até 2013, no entanto, 1,6 milhão desses jovens estavam fora da Escola sem concluir o ensino médio. E mesmo aqueles que estão estudando têm dificuldades para chegar a essa etapa: cerca de 2 milhões ainda estão retidos no Ensino fundamental. Se não forem pensadas e implementadas políticas que garantam que os jovens avancem no sistema educacional com aprendizagem adequada e na idade certa, dificilmente conseguiremos mantê-los na escola. 
Para apoiar a questão da aprendizagem adequada, é muito importante que os direitos de aprendizagem para o ensino fundamental também sejam encaminhados pelo MEC ao Conselho Nacional de Educação (CNE), precedidos de consulta pública, até o final do segundo ano de vigência do plano, ou seja, até junho do próximo ano. Também nesse prazo deve ser definida uma política de avaliação e supervisão das instituições públicas e privadas que prestam atendimento a alunos com deficiência; devem ser asseguradas as condições para a efetivação da gestão democrática da Educação; deve ser definido o Custo Aluno Qualidade Inicial (CAGI), e regulamentado o Sistema Nacional de Educação.

Além dos prazos à vista para o cumprimento das metas intermediárias e estratégias do PNE, é imprescindível que os gestores e toda a sociedade tenham a Educação, efetivamente, como prioridade absoluta e que sejam feitos os investimentos necessários para o cumprimento das metas estabelecidas para 2024 desse que é o plano norteador desta década, buscando convergir esforços para que a Educação brasileira avance de maneira efetiva. Outra conquista do PNE foi a garantia de 10\% do Produto Interno Bruto (PIB) para a financiamento da Política de Educação no país.

Portanto, o foco é trazer para a reflexão, de forma sumária e introdutória, a relação direta que existe entre governança nos sistemas e organizações educacionais e a gestão escolar, e de que forma a governança se constitui em um dos fatores importantes para que se possa, no âmbito da educação, promover a cidadania, a diversidade, os direitos humanos e o desenvolvimento sustentável. As práticas de sucesso de governança criam condições estruturais e operacionais que contribuem e facilitam sobremaneira para que os objetivos educacionais sejam alcançados e se produza a eficácia social atribuída à escola, seja ela pública ou privada. Em virtude dessa escolha, cada vez mais, de forma acentuada, tem-se discutido e experimentado conceitos e práticas de governança em educação, processo que se pode considerar como irreversível (ALVES, 2012, p. 131).

Destarte, Oliveira (2004) defende que a sociedade possui diferentes formas de socialização com as novas gerações, na relação de ensino-aprendizagem do educador Paulo Freire. A socialização começa na família e não existe, porém, um único modelo de família a ser seguido entre as diferentes sociedades. Portanto, o Estado, através de políticas públicas, tem o dever de proporcionar condições objetivas para que cada segmento cumpra o seu papel na defesa da educação de qualidade e condições dignas de sobrevivência, já que nosso país, 
apesar dos avanços, ainda se destaca pelas desigualdades sociais abissais e gritantes com resquícios de criminalização e estigmatização da pobreza.

A educação sempre contribuiu para o desenvolvimento da sociedade. As estratégias utilizadas nos processos educacionais que podemos destacar consistem na democratização do acesso à educação, à tecnologia e à evolução da cultura, em que a defesa do pluralismo e da diversidade deve ser uma premissa a ser seguida neste cenário atual. Considerando o papel da educação na atualidade, Edgar Morin (2003) alega que a educação "deve reforçar o respeito pelas culturas":

A educação deve reforçar o respeito pelas culturas, e compreender que elas são imperfeitas em si mesmas, à margem do ser humano. Todas as culturas, como a nossa, constituem uma mistura de superstições, ficções, fixações, saberes acumulados e não-criticados, erros grosseiros, verdades profundas, mas essa mescla não é discernível em primeira aproximação e é preciso estar atento para não classificar como superstições saberes milenares, como, por exemplo, os modos de preparação do milho no México, que por muito tempo os antropólogos atribuíram a crenças mágicas, até que se descobriu que permitiam que o organismo assimilasse a lisina, substância nutritiva que, por muito tempo, foi o seu único alimento. Assim o que parecia irracional respondia a uma racionalidade vital (MORIN, 2003, p. 105).

A escola na contemporaneidade reflete as formas de organização da sociedade e do capital. A educação é prioritariamente um instrumento que serve ao desenvolvimento de potencialidades para o mundo da produção. Nesse contexto emergem desigualdades no que tange ao acesso e às prioridades, competências e interesses dos indivíduos. Paulo Freire (2002) aponta como forma de luta frente aos desafios que se impõem à educação nos dias atuais, caberá aos sistemas educacionais desenvolver critérios práticos e democráticos no âmbito da escola, envolvendo todos os atores sociais. Vale aqui refletir sobre o que foi ressaltado por Paulo Freire (2011) ao afirmar que as mudanças na escola não podem ser pensadas de cima para baixo, mas devem ser a representação "viva" das necessidades, inquietudes, utopias da própria escola, daqueles que a constituem, para que se possa fazer frente às contínuas mudanças ocorridas na sociedade atual, partindo do "saber fundamental: mudar é difícil, mas é possível".

$\mathrm{Na}$ obra de Freire "Pedagogia da Autonomia: saberes necessários à prática educativa", o autor discorre que "uma das tarefas essenciais da escola, como centro de produção sistemática de conhecimento, é trabalhar criticamente a inteligibilidade das coisas e dos fatos e a sua comunicabilidade" (FREIRE, 2011, p. 121). 
Sob esta perspectiva, priorizar a educação e possibilitar que a escola cumpra o seu papel transformador é a proposta até aqui defendida nessa trilha científica. Para que as pessoas exerçam efetivamente a cidadania e vislumbrem melhores condições de vida e de trabalho, vale cada um e cada uma buscar formas críticas e propositivas de contribuir para que a sociedade se humanize e se politize. Talvez isso tenha sido o grande legado de Freire.

Nos últimos anos, algumas mudanças sociais ocorridas em vários setores da sociedade impulsionou o desenvolvimento tecnológico, fato que inova o capitalismo. Isso possibilitou mudanças nas relações de trabalho, exigindo maiores e novos domínios de conhecimentos e habilidades inovando assim a educação, a escola e o ensino. No caso específico de Luziânia, o Conselho Municipal de Luziânia, em consonância com o Instituto Federal de Goiás, vem atuando em prol do desenvolvimento local, tendo a educação e a EPT como propulsoras deste esforço coletivo.

\subsection{Educação Profissional e Tecnológica: Os Desafios da Expansão no Brasil}

A Educação Profissional e Tecnológica, apesar de sua história centenária, propôs como estratégia governamental de expansão da Rede Federal de Educação Profissional, Científica e Tecnológica (Rede de EPCT), em 29 de dezembro de 2008, a sanção da Lei 11.892. Neste contexto, tínhamos no Brasil até o ano de 2002, 140 instituições sob responsabilidade federal. No período de 2003 a 2010 foram implantadas 214 instituições, e entre 2011 e 2014 mais 208, totalizando uma Rede Federal com 562 instituições.

Portanto, em doze anos, se implantou um número três vezes maior do que o já existente e, nesse período, chega-se a uma média geral de 35 instituições implantadas por ano. Alguns estudos apontam para possíveis falhas de planejamento no período que culminou a expansão, com gastos incompatíveis com a situação do país naquele determinado contexto histórico. No primeiro período citado, os valores passaram de um 1,5 bilhão e, de 2011 a 2014, passaram dos 3,3 bilhões, segundo a Secretaria Tecnológica do MEC - SETEC. Na passagem dos anos 1990 para os anos 2000, houve no cenário nacional o entendimento de que as instituições federais de educação profissional estavam se constituindo como um degrau para o alcance de vagas em universidades, tendo em vista que a Rede Federal ofertava e ainda 
oferta um ensino médio considerado superior ao de instituições sob responsabilidade dos estados, por exemplo, e até mesmo as chamadas escolas particulares.

A história que nasce com a chegada dos portugueses e perpassa quase 400 anos (1500-1889), culminando na Proclamação da República, nos remete ao chamado ensino de ofícios artesanais e manufatureiros, antecedente da educação profissional. Sob tal prisma, o ensino de ofícios passou a ser destinado a quem não tinha condições de rejeitá-lo, ou seja, aos escravos, às crianças largadas nas Casas das Rodas, aos "meninos de rua", aos delinquentes e a outros desafortunados (CUNHA, 2005, p. 23).

É importante citar também a atuação da igreja na formação de artesãos. Foi o caso dos colégios e residências jesuítas, em que se ensinava, principalmente carpintaria, a crianças e adolescentes preferencialmente. No contexto do Império, destaca-se o crescimento dos efetivos militares e, com isso, a demanda por artífices para trabalharem em suas instalações. Cita-se, portanto, os arsenais de guerra e os ofícios na Marinha. No Rio de Janeiro, por exemplo, havia duzentos jovens em aprendizado no Arsenal de Guerra (CUNHA, 2005).

Igualmente importante foi a atuação de entidades filantrópicas no ensino de ofícios. Cunha (2005, p. 113) contabiliza a constituição de dez Casas de Educandos durante o Império, sendo a primeira criada no Pará em 1840 e a última na Paraíba, em 1865.

De acordo com Cunha (2005, p. 144), a Sociedade Auxiliadora da Indústria Nacional encerrou suas atividades provavelmente em 1891 ou 1892, visto que "o Governo republicano, não vendo com simpatia uma sociedade considerada reduto de monarquistas, cortou-lhe todos os subsídios".

De outra forma, alguns dos liceus de artes e ofícios se beneficiaram com a proclamação da república, a exemplo do liceu paulista que, segundo Cunha (2005a), muitos dos sócios eram republicanos e ocuparam cargos de destaque no Estado, possibilitando aumento das doações e subsídios. É com essa visão que se passará a analisar o período embrionário da educação profissional no Brasil.

Durante o regime militar (1964-1985), a educação profissional também demonstrou uma evolução considerável. A ênfase dada a essa modalidade é constatada, por exemplo, com o fortalecimento da atuação internacional na educação brasileira, sobretudo por meio da Agência dos Estados Unidos para o Desenvolvimento Internacional - USAID e da Aliança para o Progresso, a partir de 1965; e a universalização do currículo técnico- 
profissional no segundo grau vinda com a Lei ${ }^{0}$ 5.692, de 11 de agosto de 1971, que também procurou extinguir, sem êxito, o entendimento da educação profissional enquanto um sistema de ensino (MACHADO, 1982).

No ano de 1994 foram instituídos o Sistema e o Conselho Nacional de Educação Tecnológica, por meio da Lei $\mathrm{n}^{\mathrm{o}}$ 8.948, de 8 de dezembro, com vistas a integrar as Escolas Agrotécnicas Federais aos Serviços Nacionais de Aprendizagem Industrial, Comercial e Rural. Entretanto, esses Sistema e Conselho só se efetivaram em 1998 com a Lei $\mathrm{n}^{\circ}$ 9.649, de 27 de maio, que dispôs sobre a organização da Presidência da República e dos Ministérios, identificando a educação tecnológica como competência do Ministério da Educação (MEC). Foi também no final dos anos 1990 que surgiram o Programa de Expansão da Educação Profissional (PROEP), criado pela Portaria MEC n. ${ }^{\circ}$ 1.005, de 10 de setembro de 1997 (BRASIL, MEC, 1997), e o Fundo de Fortalecimento da Escola (FUNDESCOLA).

Assim, passaram a assumir posição equiparada às universidades federais, com a especificidade de ofertar desde cursos técnicos integrados ao ensino médio, técnicos subsequentes, superiores de tecnologia, licenciaturas e bacharelados, até pós-graduações lato e stricto sensu. Igualmente, ficou estabelecida a Rede Federal de Educação Profissional, Científica e Tecnológica. (BRASIL, 2008).

Neste ponto, é imprescindível citar o Programa Nacional de Acesso ao Ensino Técnico e Emprego (PRONATEC), criado pelo Governo Federal em 2011, com o objetivo de ampliar a oferta de cursos de educação profissional e tecnológica (BRASIL, MEC, 2013b).

A Expansão da Rede se deu com maior efetividade no período de 2003 a 2010, reiterando, deste modo, a compreensão de que a atual Rede de EPCT é herdeira dos diversos movimentos que ocorreram ao longo de sua concepção, implantação e efeitos. Assim, o histórico da Rede de EPCT demonstra ganhos significativos em sua organização, passando pela transformação das instituições em autarquias federais, sua expansão recente e consequente aumento do leque de cursos oferecidos, bemcomo a equiparação com as universidades federais.

Neste contexto, objetivando uma maior interlocução da Política de Educação com a Gestão da Educação Profissional e Tecnológica (EPT), a Secretaria de Educação Profissional e Tecnológica do Ministério da Educação - SETEC/MEC, segundo Pacheco (2008), "tem trabalhado na construção de políticas públicas de qualificação e expansão da educação profissional e tecnológica em todo território nacional". 
Levando-se em consideração que milhares de jovens e adultos não concluíram os estudos inerentes a educação básica no tempo correto, a SETEC/MEC tem proposto para o conjunto de suas ações (PACHECO, 2008):

- A indissociabilidade entre formação geral e profissional na perspectiva da educação integral;

- A vinculação orgânica entre as políticas educativas para a EPT e os arranjos produtivos, sociais e culturais das diferentes regiões brasileiras.

Em outras palavras, a SETEC/MEC tem procurado articular educação integral (formação geral e profíssional e tecnológica) ao desenvolvimento econômico e social em uma dinâmica cujo objetivo principal é a inclusão de milhares de mulheres e homens deixados à margem da sociedade brasileira, seja no que tange à escolaridade, seja na perspectiva do trabalho.Sob esta perspectiva, o mesmo autor afirma que a SETEC/MEC, de forma incisiva, tem desenvolvido as seguintes ações:

- Expansão da Rede Federal de Educação Profissional e Tecnológica;

- Programa de Integração da Educação Profíssional a Educação Básica na modalidade de Educação de Jovens e Adultos (PROEJA);

- Articulação do ensino médio à educação profissional nas modalidades integrada, concomitante e subsequente;

- Catálogo dos Cursos Superiores de Tecnologia e Catálogo dos Cursos Técnicos;

- Formação de professores para a educação profissional e tecnológica;

- Escola de Fábrica;

- Revisão da legislação no campo da EPT, dentre outras.

Esta pesquisa se ampara nas diretrizes adotadas pela SETEC/MEC, a qual tem suas competências institucionais traçadas pelo Art. 13 do Decreto $\mathrm{n}^{\mathrm{o}} 7.690$, de 2 de março de 2012. Tal Secretaria defende que só o debate e a ampla participação de diferentes segmentos da sociedade consolidam políticas democráticas, republicanas e cidadãs. A articulação das 
diversas instâncias, com vistas à integração das políticas públicas para EPT, deve assegurar, enquanto diretrizes norteadoras (PACHECO, 2008):

- A concepção de educação integral;

- A concepção de Educação Profissional e Tecnológica como processo pautado na investigação científica a fim de promover o desenvolvimento da ciência e tecnologia e da inovação tecnológica;

- O compromisso com a democratização das conquistas e benefícios da produção do conhecimento, na perspectiva da cidadania e da inclusão;

- A possibilidade de acesso e permanência para todos os alunos;

- O estabelecimento das competências das diferentes esferas de governo e organismos civis;

- $\mathrm{O}$ atendimento de demandas identificadas com a cultura produtiva e social local/regional;

- A participação de instituições representativas de trabalhadores, movimentos sociais, segmento empresarial/patronal e governo na elaboração, gestão e avaliação das políticas de EPT;

- A criação e a valorização de fóruns e colegiados como instâncias propositivas e deliberativas de políticas de EPT.

- Consolidação de relação com as unidades federativas através do Fórum de Gestores Estaduais da EPT.

Para tanto, é preciso desenvolver a atitude participativa, no sentido estrito do termo "participação", dos sujeitos envolvidos no processo educativo. Configura-se, assim, única forma viável, de diminuir a desigualdade no acesso as oportunidades no que tange não só à formação técnica específica para um determinado fazer, mas, principalmente, à implementação de uma prática pedagógica que desenvolva no educando a compreensão global do processo produtivo, com a apreensão do saber tecnológico e do conhecimento que dá forma ao saber técnico e ao ato de fazer, com a valorização da cultura do trabalho e com a mobilização dos valores necessários à tomada de decisões profissionais e ao monitoramento dos seus próprios desempenhos profissionais (BRASIL apud CARDOZO, 2010). 
Para que a Educação Profissional e Tecnológica se consolide cada vez como política pública, a participação dos diversos segmentos sociais na proposição e aprimoramento da EPT se faz necessário. Apesar dos avanços e da expansão ter sido parte da agenda governamental nos últimos anos, há ainda lacunas a serem preenchidas. Para melhor compreensão deste cenário, o estudo sobre a realidade do IFG em Luziânia - Goiás traz algumas características que tendem a instigar o debate sobre essa modalidade educacional, que tem na inovação tecnológica, seu diferencial.

\subsection{A Contextualização Histórica do Câmpus do IFG em Luziânia - GO}

Com a expansão da Rede de Institutos Federais nos últimos cinco anos, o IFG em Luziânia - GO, que dista aproximadamente 60 km de Brasília-DF e 200 km de Goiânia-GO, foi implantando numa região periférica, em um bairro denominado Vila Esperança. Segundo o IBGE (2010), a população de Luziânia é de 174.546 habitantes. O Censo define ainda os seguintes dados: 87.108 homens, 87.748 mulheres, sendo que 162.835 compõem a população urbana e 11.711 pessoas residem na zona rural do município. Uma pesquisa da Companhia do Planejamento do Distrito Federal - CODEPLAN, efetuada em diversos municípios do entorno de Brasília em 2013, destaca que há índices de baixa escolaridade, com alta taxa de analfabetismo e forte dependência dos serviços públicos ofertados na Capital Federal.

Após cinco anos de atuação, pode-se avaliar positivamente a instalação deste órgão representativo da educação tecnológica e superior na cidade, que vem contribuindo gradativamente para o desenvolvimento local e regional. De acordo com informações da Coordenação de Registros Acadêmicos do IFG, Câmpus Luziânia, em 17 de agosto de 2015, há aproximadamente 518 alunos regularmente matriculados, divididos nos seguintes cursos:

a) Bacharel em Sistemas de Informação - 53; b) Licenciatura em Química - 130; c) Tecnologia em Análise e Desenvolvimento de Sistemas - 50; d) Técnico Integrado ao Ensino Médio em Edificações - 81; e) Técnico Integrado ao Ensino Médio em Informática para Internet - 95; f) Técnico Integrado ao Ensino Médio em Manutenção e Suporte em Informática (EJA) - 10; g) Técnico Integrado ao Ensino Médio em Mecânica - 91; e h) Técnico Integrado ao Ensino Médio em Química - 91. 
Deste total de 518 alunos matriculados, a Coordenação de Assistência Estudantil acompanha sistematicamente 196 alunos que recebem o auxílio estudantil através da seleção socioeconômica efetuada anualmente, geralmente no início das aulas do primeiro semestre letivo, através de edital institucional, advindo da Pró-Reitoria de Extensão, lotada em Goiânia - GO. Vale ressaltar que a Coordenação de Assistência Estudantil acompanha ainda e gerencia o repasse dos recursos financeiros a todos os alunos matriculados nos Cursos Técnicos Integrados e de Jovens e Adultos (EJA), conforme determina a Política Nacional de Assistência Estudantil. Além disso, todos os alunos matriculados são acompanhados pelo Serviço Social, com acompanhamento sociofamiliar, orientações e encaminhamentos diversos, de acordo com as demandas, que podem ser espontâneas ou oriundas de encaminhamentos dos demais setores do Instituto, especialmente, da Coordenação de Apoio ao Discente.

Como estratégia de uma real efetivação da EPT, existe uma articulação de diversos profissionais que atuam no IFG, que participam e que pretendem participar como representantes nos diversos Conselhos Municipais, principalmente nas áreas de Educação, Assistência Social e Saúde. A experiência da participação em diversos níveis e com representatividade de diversas camadas da sociedade no Instituto Federal de Goiás em Luziânia - GO vem se consolidando gradativamente.

Além das representações sindicais e estudantis, desde sua implementação, o IFG local tem se destacado na participação efetiva dos servidores e docentes nos diversos fóruns de discussão e instâncias de decisão, seja ele interno ou externo, extrapolando os níveis institucionais. Um dos Conselhos que se destaca neste cenário é o Conselho do Câmpus (CONCÂMPUS), que foi criado em julho de 2015, após mobilização de alunos, professores e técnico-administrativos, com votação direta e eleição de 8 representantes, sendo: 2 representantes dos Servidores Técnico-Administrativos; 2 representantes dos discentes; 2 representantes titulares e 1 suplente dos professores 1 representante dos Coordenadores de Cursos. Vale ressaltar que o pesquisador dessa dissertação atuou como Presidente da Comissão Eleitoral e com o apoio dos demais servidores que compuseram a referida Comissão (representantes dos segmentos docente, discente e técnico-administrativos) assegurou a democracia e a participação em sua magnitude em todo o processo da escolha representativa. Após as eleições, a direção do Câmpus está se mobilizando para garantir a participação de diversos representantes considerados natos, do próprio IFG, da comunidade e 
do Conselho Municipal de Educação, para que, após os debates necessários de todos os atores sociais envolvidos neste Conselho, as decisões sobre o IFG local sejam tomadas.

Conforme arquivos da Gerência de Pesquisa, Pós-graduação e Extensão GEPPEX, do IFG, há mais de dois anos foram criados os Grupos de Flauta Doce e Coral do Câmpus Luziânia. Tais grupos artístico-culturais são compostos por estudantes do IFG e comunidade de Luziânia e se apresentam nos diversos eventos do Câmpus e até mesmo em outras atividades do IFG, a convite da Reitoria e Diretorias dos demais Campi. O Grupo de Flauta Doce é formado por 11 componentes e tem um aluno como Maestro. De acordo com este aluno, líder, o referido Grupo geralmente em suas apresentações "toca" a chamada "Música de Câmara" (para grupos pequenos em locais fechados). O repertório varia entre música popular brasileira, rock clássico e músicas de J. Bach.

Destaca-se a importância de maior interlocução entre todos os Conselhos, nos quais o IFG se dispõe a ser um representante do Poder Público, não medindo esforços em contribuir para o fomento de maior articulação entre as Entidades Governamentais e NãoGovernamentais, visando fortalecer a relação entre o Estado e a sociedade civil organizada, ora representada por sindicatos, associações, igrejas e outras camadas da Sociedade Civil e dos Movimentos Sociais e Populares.

Ressalta-seque na gestão da Educação como Política Pública, a presença da sociedade civil é indispensável: menos como braço do Poder Executivo, e mais como interlocutora, representante de interesses coletivos. Vale salientar que a educação é elemento fundamental para a vida em sociedade, não sendo possível refazer e democratizar o país, sem pensar em políticas públicas capazes de responder às demandas apresentadas no cotidiano dos atores sociais envolvidos.

\subsubsection{A Cidade de Luziânia-GO: Breve Histórico}

A formação da cidade de Luziânia, em Goiás, está relacionada com a ocupação aurífera e o bandeirantismo do século XVIII. Antônio Bueno de Azevedo partiu de Paracatu MG e em 14 de dezembro de 1746 para o povoado Santa Luzia. As minas atraíram tanta gente que em menos de um ano o arraial contava com mais de 10.000 pessoas (PME, 2015). Já na primeira missa, celebrada em 1746, registrou a presença de 6.000 garimpeiros, indicando a 
urbanização desordenada, típica do período. Marcava também o que seria uma continuidade ao longo da história da região, qual seja a desigualdade. Nesses anos de 1800, o trabalho era realizado por escravos, da garimpagem até a construção de obras, como em abril de 1758 a de um rego denominado Saia Velha, em 1758, para facilitar a exploração aurífera, que tinha 42 quilômetros de extensão.

O primeiro núcleo de povoamento já era chamado de Arraial de Santa Luzia em fins do século XVIII. O arraial foi elevado à categoria de vila em $1^{\circ}$ de abril de 1833 e à de cidade em 5 de outubro de 1867. Contudo, foi somente a partir de 31 de dezembro de 1943 que passou a se denominar "Luziânia". A aproximação com os círculos exteriores a sua geografia, só foi especialmente intensificada com a chegada de grandes levas de imigrantes, oriundos de diversos lugares, a partir da construção de Brasília em meados do século XX. Fato este que inseriu Luziânia, com destaque, em uma nova perspectiva histórica: a moderna história nacional. Desta forma, a cidade passou a fazer parte do entorno de Brasília, conhecido como Região Integrada de Desenvolvimento do Distrito Federal e Entorno (RIDE), pois está situada a cerca de $60 \mathrm{~km}$ da capital federal e de $200 \mathrm{~km}$ da capital goiana.

O fluxo populacional e a ligação direta com o Distrito Federal ampliaram a área urbana de Luziânia, onde houve mudanças nas redes de transportes e comunicação, reconfigurando a economia, aumentando a participação do setor terciário e fortalecendo os setores das tecnologias, modernizando principalmente a indústria e a agricultura. Neste sentido, faz-se necessário conhecer as tendências de crescimento da população, a base produtiva, mercado de trabalho e agricultura familiar, os desafios e avanços quanto à questão da pobreza, educação e saúde, assim como a capacidade de financiamento e gestão do município é etapa fundamental para assegurar o desenvolvimento local nos próximos anos.

Apesar dos avanços, podemos afirmar que a cidade de Luziânia possui, atualmente, características comuns a outros municípios do mesmo porte ou menores, ainda com influências culturais pautadas na religiosidade e práticas políticas assistencialistas, coronelistas e arcaicas. A cultura do favor e da benesse ainda é um entrave para a efetivação das políticas públicas. Algumas periferias localizadas no município são povoadas principalmente pela população pobre que trabalha em Brasília, o que justifica o apelido informal de Luziânia como "cidade-dormitório". A periferia tornou-se um espaço diferenciado do centro.

Não obstante, uma das características mantidas na região foram os desmandos 
políticos da elite local. Com a crise da mineração, ainda no século XVIII, gradualmente a economia local foi substituída pela pecuária e a agricultura, concentrando poder nas mãos de algumas famílias. De acordo com Rocha (2012), “As principais famílias de Luziânia vieram em sua maioria no período da mineração do ouro". Esses grupos do período colonial se mantiveram no poder.

Para Reis (1929), é comprovado que o poder político da cidade continua nas mãos de uma minoria. Ele organiza a genealogia de todas as famílias tradicionais da cidade entre o período aproximado de 1800 e 1929. O atual prefeito da cidade e o atual Presidente da Câmara Municipal são todos da mesma linhagem familiar, que teve origem com o casamento entre um Roriz e uma Meireles (REIS, 1929).

Favorecida pelo isolamento da região, pela concentração da propriedade rural, pelo uso da força e pela fidelidade da população, os Bulhões, os Xavier de Almeida e os Caiado, se destacaram entre grupos familiares que mantiveram o domínio na região. Outros grupos familiares, como os Roriz, surgiram posteriormente. Ocupando cargos no alto escalão, essa elite utilizou como estratégia a política do atraso. Isto resultou em práticas clientelistas, manipulação de orçamentos, barganha eleitoral e dominação pessoal. Mesmo com a construção de Brasília, o cenário político não se alterou. Ainda que as ações coronelistas tradicionais da República Velha tenham mudado, o clientelismo praticado por esses grupos familiares se adaptou às novos formatos de dominação política.

Dessa forma, há um clientelismo moderno que se compromete em colocar os políticos de profissão acima dos cidadãos. Aqueles oferecem a estes, em troca da legitimação e apoio, acesso a cargos e empregos públicos, financiamentos, autorizações, etc. O fato de ainda haver a prática clientelista leva alguns a crerem que há um coronelismo moderno, porém Saes (1998) define o coronelismo mostrando duas características importantes, a saber: o aspecto econômico, que diz respeito à propriedade da terra, e o aspecto ideológico, que é a fidelidade do povo ao coronel.

\subsubsection{Aspectos Sociais em Luziânia - GO}

Conforme dados do último Censo Demográfico, no município, em agosto de 2010, a população total era de 174.531 residentes, dos quais 9.896 se encontravam em situação de extrema pobreza, ou seja, com renda domiciliar per capita abaixo de R\$70,00. 
Isso significa que $5,7 \%$ da população municipal vivia nessa situação. Do total de extremamente pobres, $682(6,9 \%)$ viviam no meio rural e $9.214(93,1 \%)$ no meio urbano.

No acompanhamento do Plano Brasil Sem Miséria, o Ministério do Desenvolvimento Social e Combate à Fome (MDS) utiliza as informações do Cadastro Único para Programas Sociais do Governo Federal. Ele provê dados individualizados, atualizados no máximo a cada dois anos, sobre os brasileiros com renda familiar de até meio salário mínimo per capita, permitindo saber quem são, onde moram, o perfil de cada um dos membros das famílias e as características dos seus domicílios.

De acordo com os registros de março de 2013 do Cadastro Único e com a folha de pagamentos de abril de 2013 do Programa Bolsa Família, o município conta com 23.841 famílias registradas no Cadastro Único e 13.018 famílias beneficiárias do Programa Bolsa Família. O município apresenta uma cobertura cadastral que supera as estimativas oficiais, de maneira que a gestão municipal do Cadastro Único deve concentrar esforços na qualificação das informações registradas e na atualização dos dados familiares. Com isso, o município poderá abrir espaço para incluir no Programa Bolsa Família as famílias em extrema pobreza já cadastradas e que ainda não recebem os benefícios (PME, 2015).

De junho de 2011 a janeiro de 2013, o município inscreveu no Cadastro Único e incluiu no Programa Bolsa Família 915 famílias em situação de extrema pobreza. Os atendimentos realizados no âmbito da rede socioassistencial também são importantes elementos para o diagnóstico do perfil social do município. O Benefício de Prestação Continuada (BPC) constitui uma das mais importantes ferramentas de distribuição de renda no âmbito da Política de Assistência Social, tendo sido instituído ainda na Constituição Federal de 1988. Além do BPC, a Assistência Social desenvolve diversos tipos de programas, ações e atendimentos, especialmente considerando seus espaços institucionais, como é o caso dos Centros de Referência da Assistência Social (CRAS) e o Programa de Atenção Integral à Família (PAIF). Vale destacar ainda a importância do Centro de Referência Especializado da Assistência Social (CREAS) e do trabalho árduo do Conselho Tutelar, dentre outros órgãos representantes da Rede de Atendimento local, que devem buscar sempre trabalhar de forma articulada e integrada, evitando sobreposições de ações e otimizando os recursos públicos em prol dos usuários da política pública de Assistência Social, que com o avento do Sistema Único de Assistência Social (SUAS), vem contribuindo para o combate às desigualdades sociais em todo o território brasileiro e especialmente em Luziânia. 
Em relação à Política Pública de Saúde, em Luziânia, os dados do Ministério da Saúde são importantes para diagnosticar a situação territorial local. No tocante à mortalidade infantil, a taxa foi de 13,77 crianças por 1.000 nascimentos, ao passo que no Estado de Goiás o número de óbitos infantis foi de 1.212 crianças e a taxa de mortalidade infantil foi de 13,62 crianças a cada mil nascimentos. De acordo com o Censo Demográfico 2010, o total da população de 15 a 29 anos era de 49.261 indivíduos (PME, 2015).

Por fim, é importante ressaltar as condições de saneamento e serviços correlatos do município, que interferem nas condições de saúde da população. Dados do Censo Demográfico de 2010 revelaram que na área rural do município, a coleta de lixo atendia 93,4\% dos domicílios. Quanto à cobertura da rede de abastecimento de água, o acesso nessa área estava em 88,5\% dos domicílios particulares permanentes e 12,1\% das residências dispunham de esgotamento sanitário adequado. Tal cenário compromete a saúde da população e impossibilita que o município se desenvolva adequadamente, acirrando a relação já conflituosa entre população e poder público.

Destarte, é importante destacar que o assistencialismo, por combinar caridade aos pobres com indiferença aos fatores causais da pobreza, além de funcionar como estratégia de produção social, reproduz, igualmente, a subalternidade. O assistido nesta modalidade de proteção social não é reconhecido (nem se reconhece) como sujeito de direitos, não participando, desta forma, de uma comunidade de semelhantes, como defende Castell (2005), e sim de uma sociedade com desigualdades abissais.

De acordo com Maria Lúcia Barroco (2008), na sociedade alienada, na ótica da Teoria Marxista, o indivíduo busca no dinheiro as formas de satisfação de suas necessidades egoístas; torna-se cada vez mais pobre como homem e isso faz do trabalhador um ser pobre em necessidades e formas de satisfação, uma vez que seus sentidos e capacidade se desumanizam.

Neste sentido, acreditamos que a violência é um fenômeno que precisa de mais aprofundamento nos estudos no município, uma vez, que a cidade Luziânia é conhecida nacionalmente, (com certo estigma), porém com dados concretos, por ser considerado como "um lugar violento", o que amedronta moradores e visitantes no cotidiano do município. Tais notícias das barbáries locais e regionais são veiculadas, quase que diariamente, na TV Anhanguera (Afiliada da Rede Globo) e demais canais, além da imprensa escrita impressa e na Internet, a exemplo do Jornal "O Popular”. 


\subsubsection{Aspectos Educacionais do Município de Luziânia - GO}

De acordo com o Observatório do Mundo do Trabalho do Instituto Federal de Goiás - IFG, ${ }^{1}$ a Microrregião do Entorno de Brasília possui 38.123,74 $\mathrm{Km}^{2}$ de área total e uma população de 1.052.406 (27,6 de densidade populacional), distribuída em 20 municípios. Desse total, $89,41 \%$ vive em área urbana e apenas 10,59\% em área rural. A população masculina $(49,88 \%)$ é levemente inferior à feminina $(50,12 \%)$. Um total de $53,88 \%$ dos habitantes da microrregião reside em suas quatro cidades mais populosas, as quais são (em ordem decrescente): Luziânia, Águas Lindas, Valparaíso e Formosa.

Segundo a tipologia da Política Nacional de Desenvolvimento Regional (PNDR), esta é uma microrregião estagnada. Os 20 municípios que compõem a Microrregião do Entorno de Brasília são: Abadiânia, Água Fria de Goiás, Águas Lindas de Goiás, Alexânia, Cabeceiras, Cidade Ocidental, Cocalzinho de Goiás, Corumbá de Goiás, Cristalina, Formosa, Luziânia, Mimoso de Goiás, Novo Gama, Padre Bernardo, Pirenópolis, Planaltina, Santo Antônio do Descoberto, Valparaíso de Goiás, Vila Boa e Vila Propício.

A Microrregião concentra em torno de $90 \%$ da população, dos empregos formais, do total de alunos matriculados nas redes de ensino federal, estadual, municipal e particular da Mesorregião Leste Goiano, na qual está localizada. Quanto ao contingente populacional, em 2010, apresentou um aumento de $29,1 \%$ em relação aos dados do ano 2000 do mesmo órgão. Portanto, trata-se de uma microrregião que convive com um processo acelerado de expansão demográfica, que tende a carregar desdobramentos sociais graves como demanda por emprego muito acima da sua oferta e inadequação entre a necessidade e a disponibilidade efetiva de equipamentos e políticas sociais.

Sob esta perspectiva, o município de Luziânia foi idealizado como núcleo formador de mão de obra especializada, por sua centralidade. A implantação de um Instituto Federal, o qual tem por objetivo formar e capacitar técnicos e licenciados abarca, de maneira geral, toda a região do entorno sul de Brasília - DF.

O Município de Luziânia e a região de influência imediata possuem uma estrutura de Ensino que oferece as seguintes modalidades de educação: Educação Pré-escolar, Ensino

${ }^{1}$ Observatório do Mundo do Trabalho do Instituto Federal de Goiás. Disponível em:

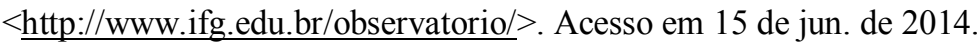


Fundamental, Ensino Médio/Normal, Ensino Especial, Educação de Jovens e Adultos, Ensino Superior, Ensino Profissional (Nível Técnico) e Creche.

Os gestores municipais avaliam a qualidade do ensino a cargo do município (da Educação Infantil ao $9^{\circ}$ ano do Ensino Fundamental e $2^{\text {a }}$ fase do EJA) e os poucos cursos superiores oferecidos, como sendo de boa qualidade. De fato, o Município apresenta um desempenho superior aos demais municípios da Microrregião. Mesmo assim, identificam uma baixa qualidade no ensino a cargo do Governo do Estado de Goiás $\left(5^{\circ}\right.$ ao $9^{\circ}$ ano do Ensino Fundamental e Ensino Médio). Os demais gestores da Microrregião reconhecem, ainda, que as limitações vividas na $2^{\mathrm{a}}$ Fase do Ensino Fundamental e no Ensino Médio se prolongam para o Ensino Superior.

A exemplo dos demais municípios da Microrregião do Entorno de Brasília, chama atenção o descompasso entre o número de alunos do Ensino Fundamental e o número de alunos de Ensino Médio/Normal, tanto no Município de Luziânia quanto na região de influência imediata. Esta realidade repercute, por sua vez, no número relativamente grande de alunos na modalidade de ensino Educação de Jovens e Adultos, uma consequência da descontinuidade dos estudos que acometeu e acomete uma parcela significativa da população jovem da região.

A modalidade de Ensino Profissional (Nível Técnico) faz-se presente na estrutura de ensino do Município de Luziânia. A oferta de Ensino Técnico pelo Câmpus Luziânia contribui para o atendimento das demandas por educação, dos alunos que concluem o Ensino Fundamental, pelo viés do Ensino Médio Integrado, bem como proporciona projetos curriculares e qualidade de formação de referência, em especial nas modalidades de Ensino Técnico Integrado e de Educação de Jovens e Adultos, este último em curso no Município e na sua região de influência.

O Ensino Superior no Município de Luziânia e na região de influência imediata era somente oferecido pela Unidade de Luziânia da Universidade do Estado de Goiás (UEG) e pelo Centro Universitário de Desenvolvimento do Centro-Oeste (UNIDESC). Predominava a oferta de Cursos de Licenciatura (Pedagogia, Letras, Matemática e Inglês), de Administração de Empresas e de Tecnologia da Informação. Não havia oferta dos cursos de Licenciatura em Química no Município de Luziânia. As instituições de ensino superior que atuam na região, predominantemente privadas, não desenvolvem projetos de pesquisa e de extensão na região de forma continuada. Essa realidade tem privado o Município e a sua região de influência 
imediata da intervenção das instituições de ensino superior, tendo em vista a resolução de demandas sociais.

O Câmpus do IFG Luziânia - atuando na Educação Profissional e Tecnológica, direcionado para as formações técnicas e tecnológicas vinculadas a indústria, a infraestrutura urbana e ao transporte e comunicação, de um lado, e para a formação de licenciados para contribuir com a elevação da oferta e da qualidade da Educação Básica na Microrregião Entorno de Brasília, de outro -, contribui para a democratização do acesso a essas modalidades de ensino e se constitui em referência de Ensino Técnico e Superior de qualidade na região.

No Município de Luziânia e na região de influência imediata, estão presentes instituições de educação que atuam nas várias modalidades de ensino. A carência percebida na região tem sido objeto de ação corretiva, com avanços quando comparado aos demais municípios da região. Essa realidade pode ser confirmada por meio do IDH - Educação que apresenta taxas superiores àquelas da região de influência imediata.

Conforme dados do último Censo Demográfico, no município, em agosto de 2010, a taxa de analfabetismo das pessoas de 10 anos ou mais era de 7,2\%. Na área urbana, a taxa era de 6,8\% e na zona rural era de $12,2 \%$. Entre adolescentes de 10 a 14 anos, a taxa de analfabetismo era de $1,9 \%$.

O percentual calculado com base no Censo de 2010 indica que há necessidade de garantir que mais pessoas tenham acesso aos estudos na idade certa, também a importância de garantir o acesso ao ensino médio, para que mais pessoas consigam completar os estudos.

O comparativo de estabelecimentos também relaciona o aumento de unidades de ensino de 101, em 2007, para 112 em 2014, porém trazendo à tona a importância de aumentar a construção de escolas para atender a demanda referente à idade de escolarização, ampliando a oferta de educação de qualidade para todos. 


\begin{tabular}{|l|l|l|l|l|}
\hline \multicolumn{5}{|c|}{ Número de Matriculas da Rede Municipal } \\
\hline \multicolumn{2}{|c|}{ Modalidades } \\
\hline & Infantil & Fundamental I & Educação de Jovens e Adultos & Total \\
\hline $\mathbf{2 0 0 5}$ & 2.219 & 19.871 & 322 & $\mathbf{2 2 . 4 1 2}$ \\
\hline $\mathbf{2 0 0 6}$ & 2.318 & 20.814 & 347 & $\mathbf{2 3 . 4 7 9}$ \\
\hline $\mathbf{2 0 0 7}$ & 2.320 & 21.006 & 358 & $\mathbf{2 3 . 6 8 4}$ \\
\hline $\mathbf{2 0 0 8}$ & 4.433 & 20.966 & 278 & $\mathbf{2 5 . 6 7 7}$ \\
\hline $\mathbf{2 0 0 9}$ & 5.052 & 19.267 & 304 & $\mathbf{2 4 . 6 2 3}$ \\
\hline $\mathbf{2 0 1 0}$ & 4.934 & 20.362 & 275 & $\mathbf{2 5 . 5 7 1}$ \\
\hline $\mathbf{2 0 1 1}$ & 5.448 & 19.503 & 250 & $\mathbf{2 5 . 2 0 1}$ \\
\hline $\mathbf{2 0 1 2}$ & 4.967 & 18.174 & 364 & $\mathbf{2 3 . 5 0 5}$ \\
\hline $\mathbf{2 0 1 3}$ & 4.606 & 17.356 & 414 & $\mathbf{2 2 . 3 7 6}$ \\
\hline $\mathbf{2 0 1 4}$ & 4.714 & 16.731 & 532 & $\mathbf{2 1 . 9 7 7}$ \\
\hline Fonte: INEP/ Educacenso. & & & \\
\hline
\end{tabular}

Nas modalidades de ensino Infantil, Fundamental I e Educação de Jovens e Adultos, observa-se que não houve muitas oscilações na quantidade de discentes matriculados na Rede Municipal de Ensino no período de 2005 a 2014.

\begin{tabular}{|c|c|c|c|c|c|c|c|c|}
\hline \multicolumn{9}{|c|}{ Número de Matriculas da Rede Estadual } \\
\hline & \multicolumn{8}{|c|}{ Modalidades } \\
\hline & \multirow[t]{2}{*}{ Fundamental II } & \multirow[t]{2}{*}{ Médio } & \multicolumn{4}{|c|}{ Educação de Jovens e Adultos } & \multirow[t]{2}{*}{ Profissional } & \multirow[t]{2}{*}{ Total } \\
\hline & & & $2^{a}$ etapa & $3^{a}$ etapa & $\begin{array}{l}\text { Semipresencial } \\
\text { fundamental }\end{array}$ & $\begin{array}{l}\text { Semipresencial } \\
\text { Médio }\end{array}$ & & \\
\hline 2005 & 14.279 & 7.183 & 0 & 0 & 0 & 0 & 0 & 21.462 \\
\hline 2006 & 15.141 & 7.504 & 1.088 & 0 & 0 & 0 & 0 & 23.733 \\
\hline 2007 & 13.557 & 7.583 & 8.777 & 1.101 & 76 & 47 & 44 & 31.185 \\
\hline 2008 & 13.907 & 7.546 & 1.328 & 1.015 & 0 & 0 & 0 & 23.796 \\
\hline 2009 & 13.901 & 8.014 & 1.303 & 793 & 0 & 0 & 0 & 24.011 \\
\hline 2010 & 13.813 & 7.869 & 1.207 & 818 & 0 & 0 & 151 & 23.858 \\
\hline 2011 & 13.761 & 8.138 & 897 & 771 & 0 & 0 & 243 & 23.810 \\
\hline 2012 & 13.398 & 7.915 & 697 & 692 & 0 & 0 & 514 & 23.216 \\
\hline 2013 & 12.772 & 7.428 & 607 & 520 & 10 & 0 & 755 & 22.092 \\
\hline 2014 & 12.241 & 7.309 & 652 & 540 & 27 & 0 & 666 & 21.435 \\
\hline
\end{tabular}

Na modalidade do ensino Semipresencial fundamental e Semipresencial Médio na Rede Municipal de Ensino, percebe-se uma exaurida quantidade, apresentando, inclusive, nenhuma matrícula na semipresencial fundamental entre os anos de 2008 a 2012. 


\begin{tabular}{|c|c|c|c|c|c|c|c|}
\hline \multicolumn{8}{|c|}{ Número de Matriculas da Rede Privada } \\
\hline \multicolumn{8}{|c|}{ Modalidades } \\
\hline & \multirow[t]{2}{*}{ Infantil } & \multirow[t]{2}{*}{ Fundamental I } & \multirow[t]{2}{*}{ Fundamental II } & \multirow[t]{2}{*}{ Médio } & \multicolumn{2}{|c|}{ Educação de Jovens e Adultos } & \multirow[t]{2}{*}{ Total } \\
\hline & & & & & Fundamental & Médio & \\
\hline 2005 & 1.545 & 1.730 & 1.338 & 380 & 248 & 0 & 5.241 \\
\hline 2006 & 1.323 & 2.249 & 1.347 & 370 & 269 & 0 & 5.558 \\
\hline 2007 & 880 & 1.448 & 1.108 & 200 & 58 & 75 & 3.769 \\
\hline 2008 & 1.008 & 1.807 & 940 & 393 & 65 & 72 & 4.285 \\
\hline 2009 & 1.145 & 1.601 & 746 & 277 & 44 & 56 & 3.869 \\
\hline 2010 & 1.386 & 2.010 & 1.027 & 361 & 12 & 0 & 4.797 \\
\hline 2011 & 1.272 & 1.969 & 964 & 325 & 5 & 0 & 4.535 \\
\hline 2012 & 1.128 & 2.079 & 1.131 & 340 & 14 & 0 & 4.692 \\
\hline 2013 & 1.028 & 2.075 & 1.079 & 317 & 6 & 0 & 4.505 \\
\hline 2014 & 1.557 & 2.090 & 1.088 & 373 & 15 & 0 & 5.123 \\
\hline
\end{tabular}

$\mathrm{Na}$ Rede Privada de Ensino, nota-se um número muito pequeno de matrículas na modalidade de Educação de Jovens e Adultos. No Ensino Médio entre 2007 e 2009 soma-se apenas 203 matrículas.

No que tange ao ensino superior, possui um Câmpus da Universidade Estadual de Goiás, que oferece os cursos de Administração e Pedagogia, além do UNIDESC (Centro Universitário de Desenvolvimento do Centro-Oeste), que é uma entidade privada. Possui também um Câmpus do Instituto Federal de Goiás, o IFG, que proporciona cursos técnicos integrados ao Ensino Médio nas seguintes áreas: mecânica, química, edificações e informática para internet. Além disso, o IFG detém a autarquia de uma faculdade, fornecendo cursos superiores de Licenciatura em Química e Bacharelado em Sistemas de Informação. A cidade conta também com um polo de apoio presencial da Universidade Anhanguera - UNIDERP, que atua na modalidade de Educação a Distância há vários anos, ofertando cursos de Graduação e Pós-Graduação. 


\begin{tabular}{|l|l|l|l|l|l|}
\hline \multicolumn{7}{|c|}{ Número de Matriculas no Ensino Superior } \\
\hline & Graduação & Pós-Graduaça & Mestrado & Doutorado & Total \\
\hline $\mathbf{2 0 0 5}$ & 0 & 0 & 0 & 0 & 0 \\
\hline $\mathbf{2 0 0 6}$ & 320 & 0 & 0 & 0 & 320 \\
\hline $\mathbf{2 0 0 7}$ & 320 & 0 & 0 & 0 & 320 \\
\hline $\mathbf{2 0 0 8}$ & 300 & 0 & 0 & 0 & 300 \\
\hline $\mathbf{2 0 0 9}$ & 4.161 & 0 & 0 & 0 & 4.161 \\
\hline $\mathbf{2 0 1 0}$ & 5.028 & 0 & 0 & 0 & 5.028 \\
\hline $\mathbf{2 0 1 1}$ & 4.888 & 0 & 0 & 0 & 4.888 \\
\hline $\mathbf{2 0 1 2}$ & 4.443 & 0 & 0 & 0 & 4.443 \\
\hline $\mathbf{2 0 1 3}$ & 292 & 0 & 0 & 0 & 292 \\
\hline $\mathbf{2 0 1 4}$ & 292 & 0 & 0 & & 292 \\
\hline Fonte: INEP/ Educacenso. & & & & 0 & \\
\hline
\end{tabular}

Nesse quadro, pode-se observar que entre 2010 e 2014 houve uma queda no número de alunos matriculados na modalidade da graduação. Os números na Pós-graduação, Mestrado e Doutorado inexistem.

O município de Luziânia recebe recursos federais abaixo relacionados destinados à educação. O repasse é feito à Prefeitura Municipal em contas específicas.

- PNAE (Programa Nacional de Alimentação Escolar);

- PNATE (Programa Nacional de Apoio ao Transporte Escolar);

- Salário Educação;

- PAC II (Programa de Aceleração do crescimento destinados a construções de creches e quadras poliesportivas);

- Brasil Alfabetizado;

- Programa Brasil Carinhoso (Apoio as creches);

- FUNDEB (Fundo de Manutenção e Desenvolvimento da Educação Básica e de Valorização dos Profissionais da Educação;

- PTA (Programa de Trabalho Anual);

Todas as despesas realizadas pela secretaria através destes programas são comprovadas por meio de prestação de contas enviadas ao Fundo Nacional de 
desenvolvimento da Educação - FNDE. É importante que estes recursos sejam gastos no decorrer do ano.

As Instituições Escolares também recebem diretamente do FNDE, em contas específicas dos conselhos escolares, as verbas do PDDE e ações que são destinadas a melhorias físicas e pedagógicas da escola, tendo como consequência a elevação do desempenho escolar.

O município de Luziânia possui um Programa de Apoio Financeiro às Escolas Públicas Municipais - PROAFEM que foi instituído de acordo com Lei no 2944 de 16 de maio de 2006 e Lei $n^{0} 3062$ de 28 de Junho de 2007, que autoriza a Secretaria Municipal de Educação a efetuar repasses aos conselhos escolares para manutenção diária com materiais de consumo das escolas. Atualmente, há 63 escolas em Luziânia, sendo 7 localizadas em Zona Rural e 4 são conveniadas. Em 2015 há 29.029 alunos matriculados desde a educação infantil até o quinto ano ensino fundamental, sendo a maioria do gênero masculino (mais de 15.000 alunos). (EDUCACENSO, 2015).

\subsection{Conselho Municipal de Educação em Luziânia - G0: Caracterização e História}

A Constituição Federal de 1988 prevê em seu art. 211 que "A União, os Estados, o Distrito Federal e os Municípios organizarão em regime de colaboração seus sistemas de ensino". Tendo tal determinação como parâmetro, foi instituído em dezembro de 1996, a Lei de Diretrizes e Bases da Educação Nacional (LDB), a qual tinha por meta definir as orientações básicas, em todos os níveis da Federação, os eixos norteadores da educação brasileira, procurando, de maneira infraconstitucional, regulamentar alguns pontos definidos na Carta Magna. A LDB, em seu início, define a abrangência da educação nacional:

Art. $1^{\circ}$. A educação abrange os processos formativos que se desenvolvem na vida familiar, na convivência humana, no trabalho, nas instituições de ensino e pesquisa, nos movimentos sociais e organizações da sociedade civil e nas manifestações culturais (LDB, 1996).

A LDB, com o intuito de garantir a participação popular, gerando um caráter democrático, começa, a partir dos seus artigos $8^{\circ}, 11^{\circ}, 14^{\circ}$ e $18^{\circ}$, formalizar uma instituição ligada ao Governo, porém com representatividade de vários segmentos da sociedade civil e do 
poder público: Art. 14 : "Os sistemas de ensino definirão as normas da gestão democrática do ensino público na educação básica, de acordo com as suas peculiaridades (...)”.

Como fruto da determinação legal, começou então a ser obrigatório a criação dos Conselhos Municipais de Educação, com o objetivo de trazer a sociedade para participar e fomentar, de maneira efetiva, os ditames educacionais de cada região.

Em Luziânia - GO, o Conselho Municipal de Educação foi instituído pela lei municipal $n^{\circ} 2.846$ de 03 de junho de 2005, o qual estabelece a competência e a abrangência de sua atuação em âmbito municipal. O citado dispositivo legal também define que o Conselho Municipal de Educação é órgão superior consultivo e deliberativo coletivo, garantindo, para o seu pleno funcionamento, parâmetros: autonomia política e autonomia administrativa independente.

Entre suas funções destacam-se a de normatizar, inspecionar, acompanhar, fiscalizar e orientar o planejamento pedagógico do ensino municipal. A lei que dispõe sobre a criação do Conselho, também atribui normas e diretrizes para o sistema de ensino do Município de Luziânia, bem como orienta, fiscaliza e acompanha o ensino das redes públicas e particulares e conveniadas, não sendo apenas a educação pública, a amplitude do órgão.

O Conselho Municipal de Educação é formado por pessoas que são eleitas para representar a população local, avaliar, fixar as diretrizes e as metas da educação municipal e buscar medidas que possam solucionar os problemas e alcançar uma educação de qualidade social.

O Plano Municipal de Educação 2014-2024, da cidade de Luziânia, define que o Conselho, além das competências legais, possui em complemento as seguintes atribuições no âmbito de sua jurisdição:

- Definir normas para organização e funcionamento do sistema de ensino municipal;

- Criar diretrizes e métodos sobre orientação, supervisão, e acompanhamento da gestão e qualidade do ensino;

- Criar mecanismos de articulação entre o sistema de ensino público e privado; 
- Estabelecer os critérios para a criação e autorização de cursos e outras atividades, como: o credenciamento e o recredenciamento das escolas da rede pública e particular;

- Emitir parecer e Resoluções sobre assuntos pertinentes à Educação.

Para Melo (2014), o Conselho Municipal de Educação “(...) foi criado para que profissionais da educação, pais de alunos, da rede pública e particular, servidores de instituições tecnológicas, instituições de ensino superior pudessem participar do sistema e dar validade aos atos praticados pelo Conselho (...)".

O Conselho Municipal de Educação é, mesmo que de maneira indireta, fruto do Estado Democrático de Direito, assegurando a população participação ativa na vida política do Estado. Para Melo:

O Conselho é a forma democrática de o cidadão exercer a cidadania ao contribuir com os projetos e programas educacionais, pois o Conselho é o órgão de instância superior no sistema educacional ao auxiliar e promover a gestão democrática e participativa, onde todos os envolvidos, como profissionais da educação e comunidade trabalhem juntos para garantir uma educação eficiente e eficaz e assim formar cidadãos conscientes e formadores de opinião (MELO, 2014).

O Conselho Municipal de Educação de Luziânia - GO é composto por 11 membros, os quais se reúnem ordinariamente 1 (uma) vez por semana, podendo se reunir de forma extraordinária quando convocado. $\mathrm{O}$ total dos seus membros é caracterizado como pleno. Cada membro advém de uma instância representativa como abaixo elencado:

A composição do Conselho Municipal de Educação de Luziânia-GO segue os seguintes critérios:

- 02 (dois) membros escolhidos pelo (a) Chefe do Poder Executivo Municipal;

- 02 (dois) membros escolhidos entre os Profissionais da Educação Pública do Município de Luziânia, sendo 01 (um) representante da Educação Infantil e 01 (um) representante do Ensino Fundamental de $1^{\circ}$ ao $5^{\circ}$ ano, com mais de três anos de efetivo exercício;

- 01 (um) membro escolhido pelas Escolas Particulares que ofertam Educação Infantil no Município de Luziânia; 
- 01 (um) membro que exerce a função de diretor nas escolas públicas do Município de Luziânia, indicado por seus pares;

- 02 (dois) membros escolhidos entre os pais de alunos de escolas públicas do município de Luziânia;

- 01 (um) membro escolhido entre os profissionais administrativos da Educação Pública do Município de Luziânia.

- 02 (dois) membros indicados pelas universidades ou institutos superiores com unidade/sede no município.

Visando garantir a lisura e transparência do Conselho, as reuniões devem ser contempladas por 6 (seis) conselheiros ou mais, formando o quórum necessário para votação, o que equivale a $50 \%$ mais 1 (um).

As atividades do Conselho acontecem nas plenárias, as quais objetivam estudar novos projetos educacionais municipais, bem como aprovar resoluções e emitir pareceres técnicos relacionados à pasta educação. Vale ressaltar que o Conselho exerce papel regulamentador local, definindo e delimitando a atuação de cada escola.

A lei de criação do Conselho Municipal de Educação determina que, para maior efetividade em sua atuação e identidade com a comunidade representada, todos os conselheiros deverão residir e ser domiciliado no município de Luziânia - GO.

No período de pesquisa, que se iniciou em 15 de outubro de 2013 e se encerrou em 15 de abril de 2015 (intervalo de 18 meses), o Conselho Municipal de Educação realizou as atividades, a saber:

- 38 (trinta e oito) reuniões plenárias;

- Aprovações de diversas Resoluções e Pareceres;

- Encontros temáticos com os Gestores das Escolas da Rede Municipal de Ensino e com a Coordenação da Educação de Jovens e Adultos e Reunião da Comissão na Elaboração do Plano Municipal de Educação - PME, aprovado em abril de 2015. 
Foi comemorado ainda os 10 anos da criação do Conselho. Na data, foi promovido um evento cuja temática culminou na palestra sobre "Mediação de Conflitos nas Escolas" com grande mobilização e participação da sociedade civil de Luziânia - Goiás. 


\section{Capítulo III - A Relação entre o Conselho Municipal de Educação e o Instituto Federal de Goiás (IFG) em Luziânia - GO: Um Estudo de Caso}

Este capítulo tratará da análise dos dados coletados em relação à pesquisa, fruto de análise documental e das entrevistas realizadas com os Conselheiros Municipais de Educação em Luziânia - GO, incluindo os representantes do IFG (Conselheiro e DiretorGeral).

Para analisar a relação entre o Conselho municipal de Educação e o Instituto Federal de Goiás em Luziânia, o presente trabalho assumiu o caráter de pesquisa qualitativa, apresentando dados primários e secundários sobre o Instituto, o Conselho e a cidade. De acordo com os estudos de metodologia científica, esse tipo de pesquisa é mais interpretativa e envolve a participação do pesquisador numa experiência intensiva, de modo que este se envolve numa experiência com os agentes pesquisados (CRESWELL, 2010).

Na realização desse trabalho foi utilizado como estratégia de pesquisa o estudo de caso, que é uma investigação empírica que averigua fenômenos contemporâneos dentro de determinado contexto, aqui a relação entre o Conselho Municipal de Educação e o IFG, no município de Luziânia.

A discussão perpassa por caminhos metodológicos a serem percorridos e avaliadas, posteriormente, as escolhas científicas do trabalho investigativo. Nesta etapa da pesquisa, objetivamos evidenciar a relação acima mencionada por meio da análise dos dados coletados e da discussão dos resultados, mensurando o grau de participação no âmbito do Conselho Municipal de Educação e o protagonismo no processo democrático do controle social, numa perspectiva participativa e em sua relação com o IFG. A utilização de leis, atas e documentos para embasar política e juridicamente a pesquisa foi contemplada.

\subsection{Caracterização Geral da Pesquisa}

O foco da Pesquisa é compreender a relação entre o Conselho Municipal de Educação e o Instituto Federal de Goiás - IFG - na cidade de Luziânia - Goiás. Ao entrevistarmos os Conselheiros, indagamos sobre o grau de participação dos mesmos no cotidiano das atividades do referido órgão e como compreendem a relação entre Conselho e o 
IFG, visando avaliar se a parceria contribui ou não para o desenvolvimento local da educação em Luziânia - GO. Para complementar a análise, optamos em entrevistar também o DiretorGeral do Instituto Federal de Goiás - IFG - Câmpus Luziânia, que é o responsável por indicar o representante do IFG para compor a representatividade da educação no âmbito municipal, e se dispôs gentilmente a colaborar com esse estudo.

Os entrevistados, que totalizaram 12 pessoas, sendo 11 conselheiros municipais e lgestor do IFG, foram bastante generosos e receptivos em relação à temática desta pesquisa. Conseguimos êxito em entrevistar todas as pessoas com representatividade no Conselho, incluindo o Diretor-Geral do IFG, considerando o período de 15 de outubro de 2013 a 15 de abril de 2015, da atual Gestão do Conselho Municipal de Educação. O gráfico abaixo retrata a representação do Conselho por gênero:

\section{GRÁFICO 1 - Representação do Conselho por Gênero}

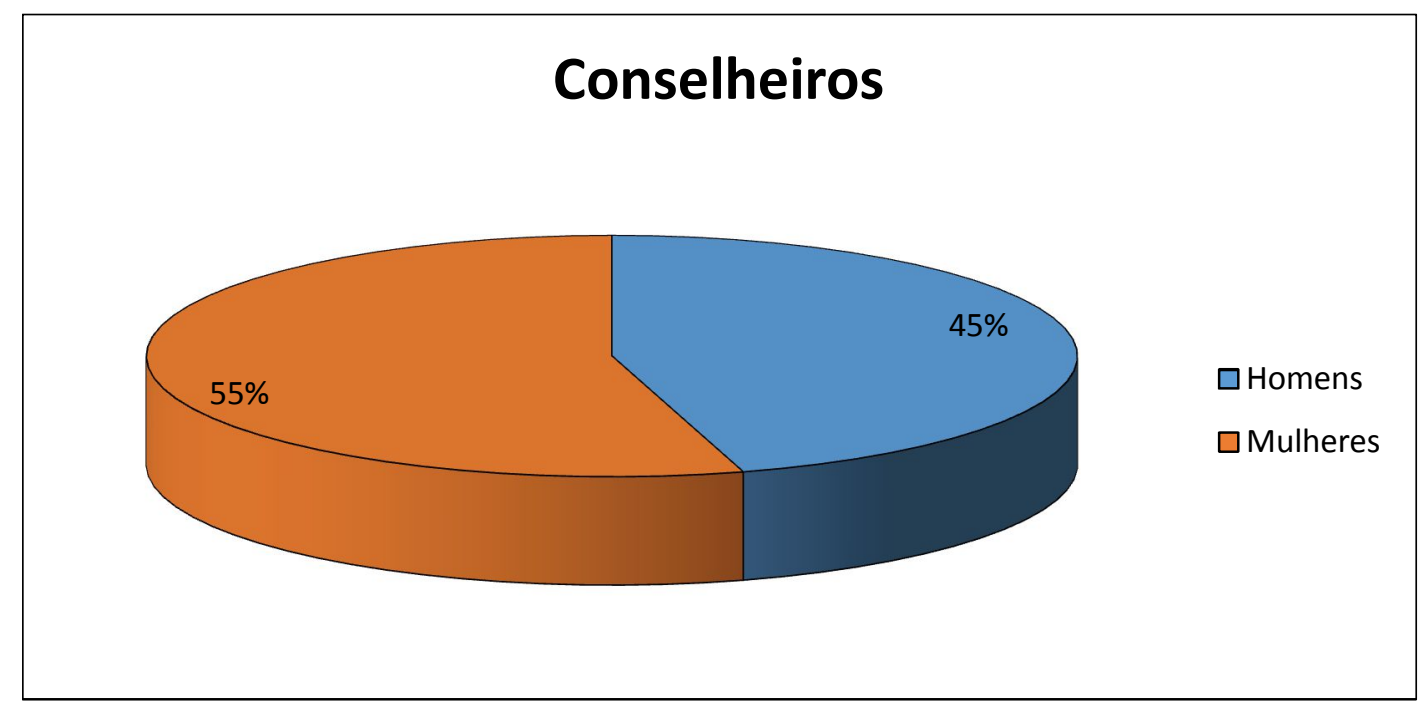

Fonte: Elaboração própria a partir da Pesquisa de Campo.

Este dado demonstra certo equilíbrio na representação do Conselho Municipal de Educação entre homens e mulheres, tendo em vista a diferença de apenas $10 \%$, sendo $55 \%$ de representantes femininas e os $45 \%$ restantes representando o gênero masculino. 
Já o próximo gráfico, retrata a faixa etária dos conselheiros Municipais de Educação em Luziânia - Goiás:

\section{GRÁFICO 2 - Representação do Conselho por Faixa Etária}

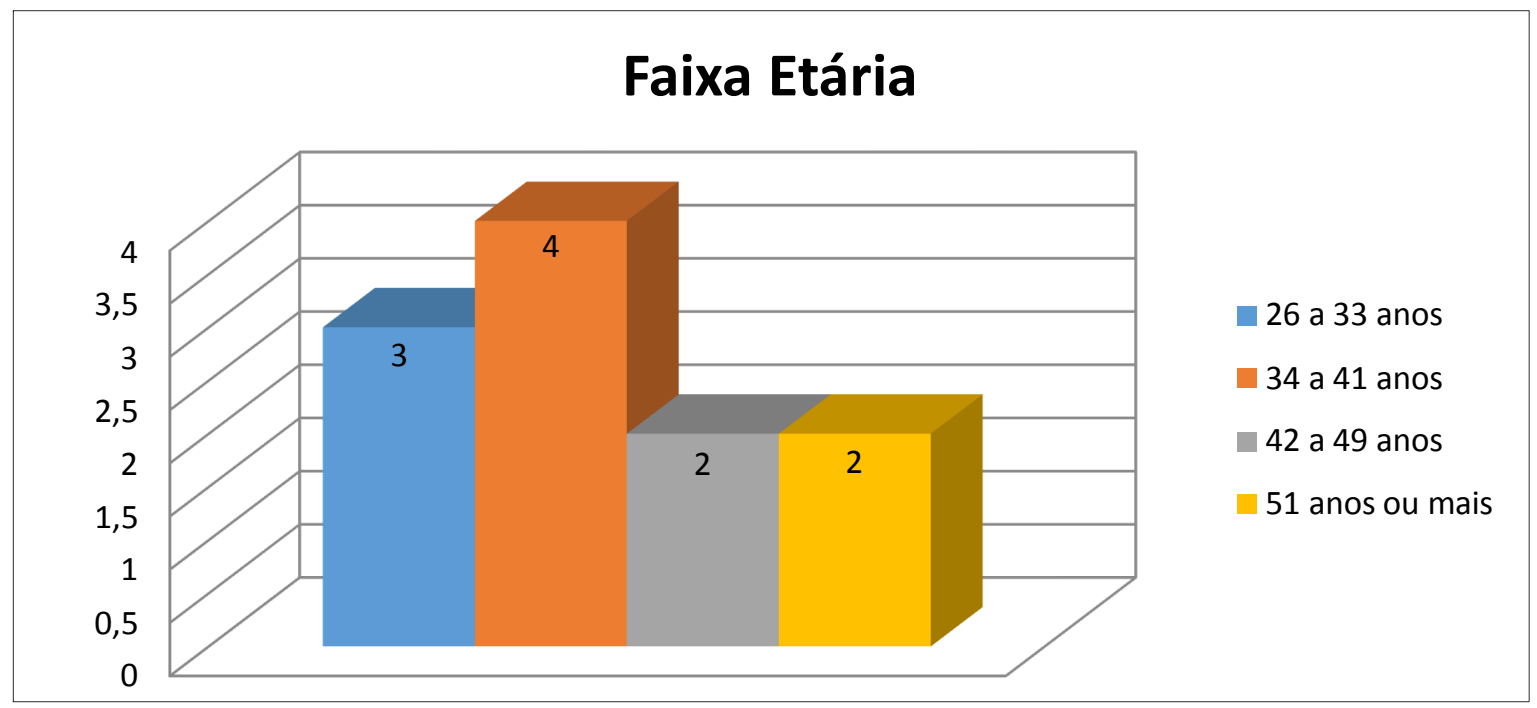

Fonte: Elaboração própria a partir da Pesquisa de Campo.

A média de idade representativa dos conselheiros é de 44 anos. Há uma predominância na faixa etária entre 34 e 41 anos de idade. Essa faixa etária evidencia certo grau de maturidade do grupo, fator que geralmente contribui na tomada de decisões e mediações de conflitos que tendem a surgir nos debates das reuniões plenárias.

Já o Gráfico que se segue, mostra o Nível de Escolaridade dos representantes entrevistados: 
GRÁFICO 3 - Representação do Conselho por Nível de Escolaridade

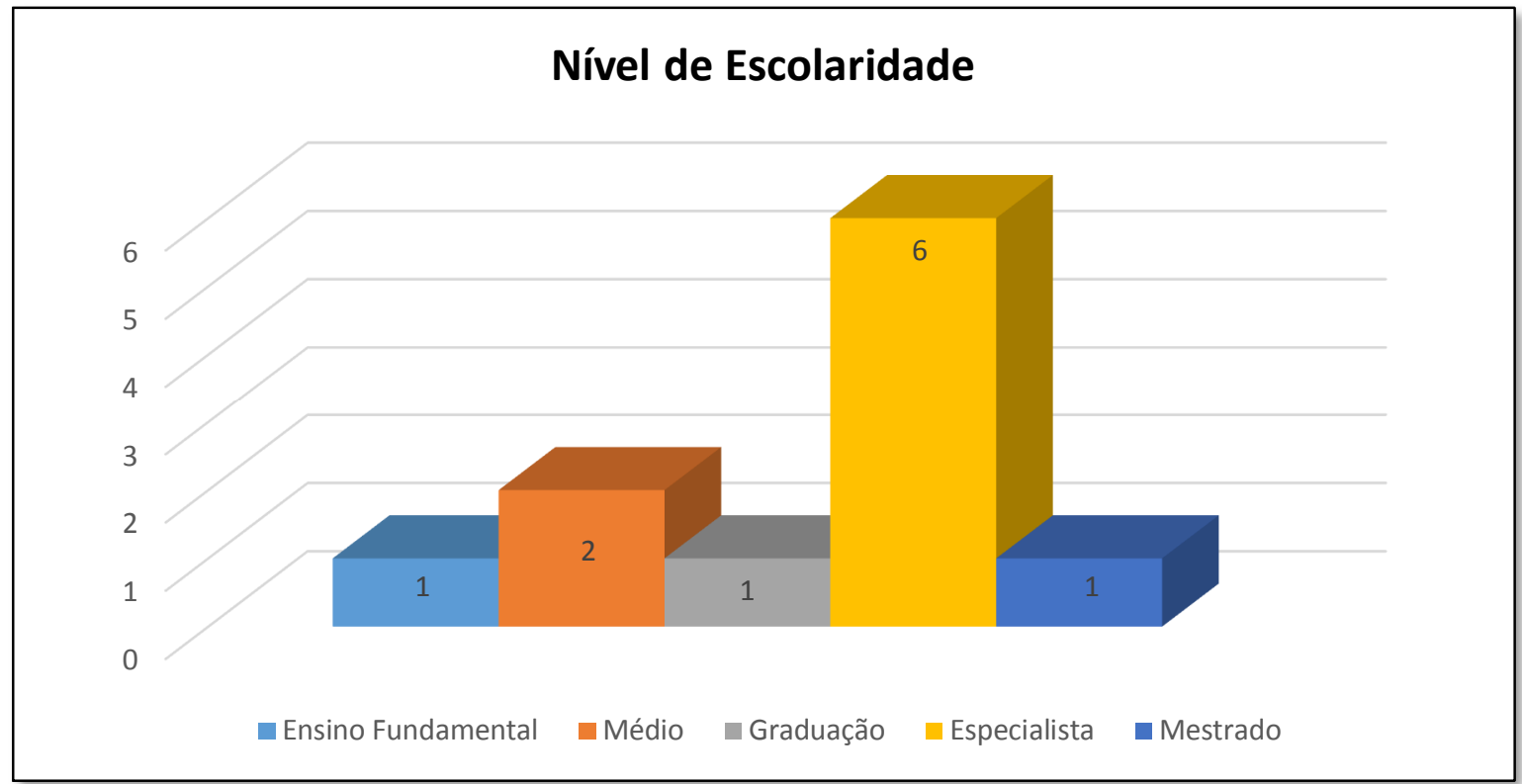

Fonte: Elaboração própria a partir da Pesquisa de Campo.

O nível de escolaridade dos conselheiros varia do Ensino Fundamental ao Mestrado, perpassando pelo Ensino Médio, Graduação e Especialização dos 11 entrevistados. Na sua maioria representativa, os Conselheiros são graduados em Pedagogia e possuem PósGraduação em Áreas Educacionais, totalizando 55\% do total dos conselheiros, ou seja, 6 especialistas em Educação do total representativo do Conselho.

O Gráfico abaixo apresenta a Área de Formação dos Conselheiros:

\section{GRÁFICO 4 - Representação do Conselho por Área de Formação Acadêmica}

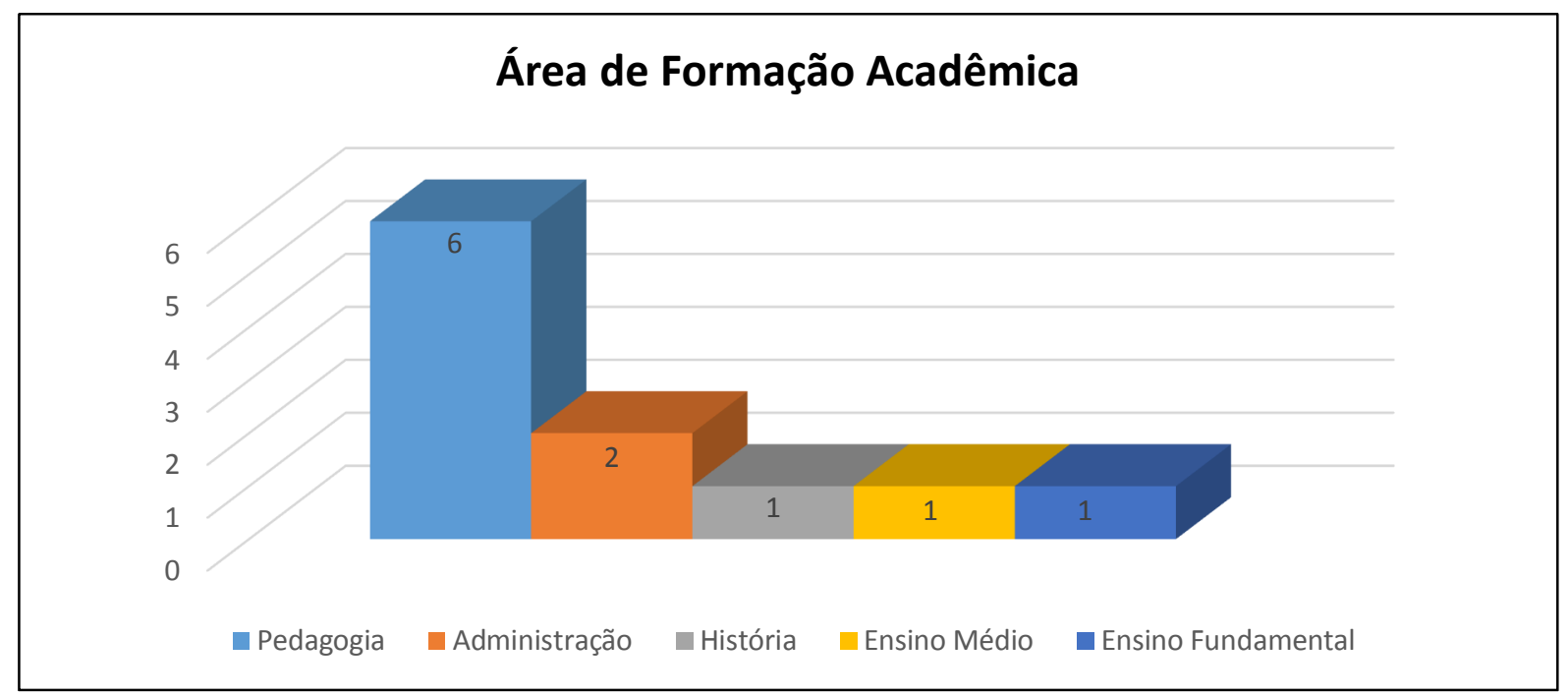

Fonte: Elaboração própria a partir da Pesquisa de Campo. 
A área de formação dos membros do Conselho é composta predominantemente por Pedagogos. No total são 6 integrantes com graduação na área pedagógica, o que contribui para validar os assuntos deliberados no cotidiano do Conselho, por se tratar de especialistas educacionais e militantes da educação, em sua maioria.

Já o gráfico que veremos a seguir, evidencia que o período analisado de 18 meses teve pouca rotatividade. A apresentação da totalidade do período analisado evidenciou que a permanência dos conselheiros entrevistados foi de um ano e cinco meses, com a saída de apenas um representante antes dos 18 meses no período analisado.

\section{GRÁFICO 5 - Representação dos Conselheiros por Tempo de Atuação}

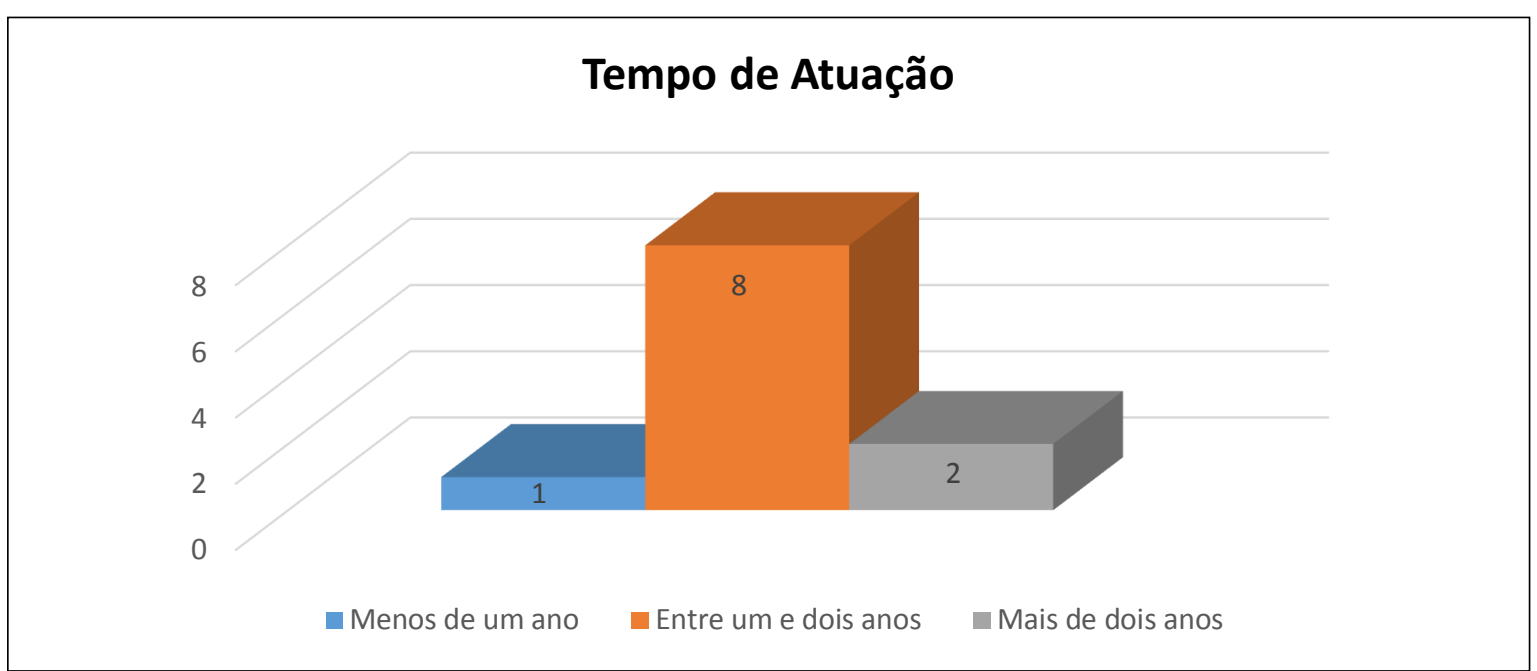

Fonte: Elaboração própria a partir da Pesquisa de Campo.

O período analisado nesta pesquisa compreende 18 meses, datados de 15 de outubro de 2013 a 15 de abril de 2015. O tempo médio de atuação dos Conselheiros entrevistados equivale a 1 ano e 5 meses, ou seja, houve pouca rotatividade dos representantes no período estudado. Dos 11 representantes do período, 10 permaneceram no Conselho por mais de 17 meses e apenas 1 ficou num período inferior a 1 ano.

No Gráfico abaixo, veremos que apenas um Conselheiro mora em outra cidade, o que fere a legislação do Conselho Municipal de Educação. 
GRÁFICO 6 - Representação do Conselho por Local de Moradia

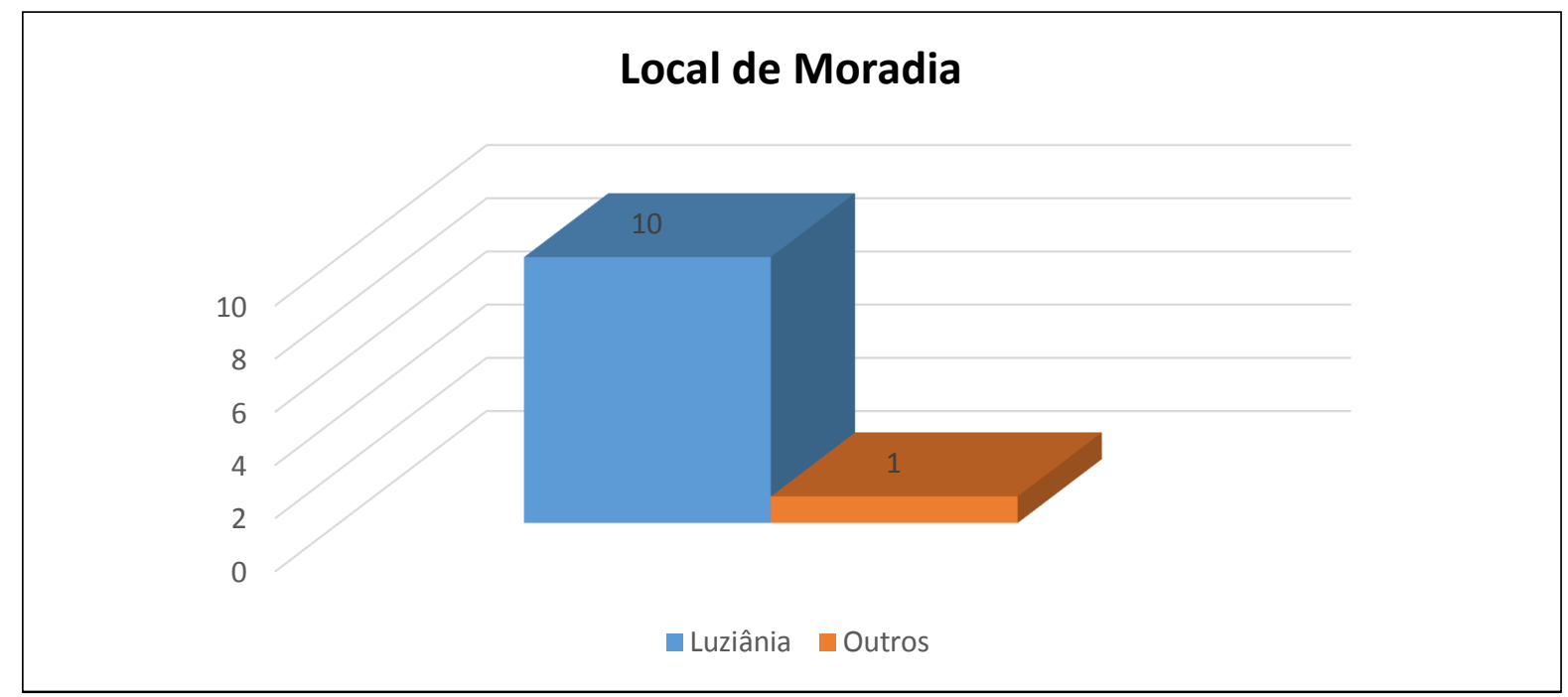

Fonte: Elaboração própria a partir da Pesquisa de Campo.

Em relação ao local de moradia dos Conselheiros, apenas um representante reside em outro município.

Já o Gráfico que se segue, mostra as áreas profissionais dos conselheiros municipais entrevistados. 
GRÁFICO 7 - Representação do Conselho por Profissão

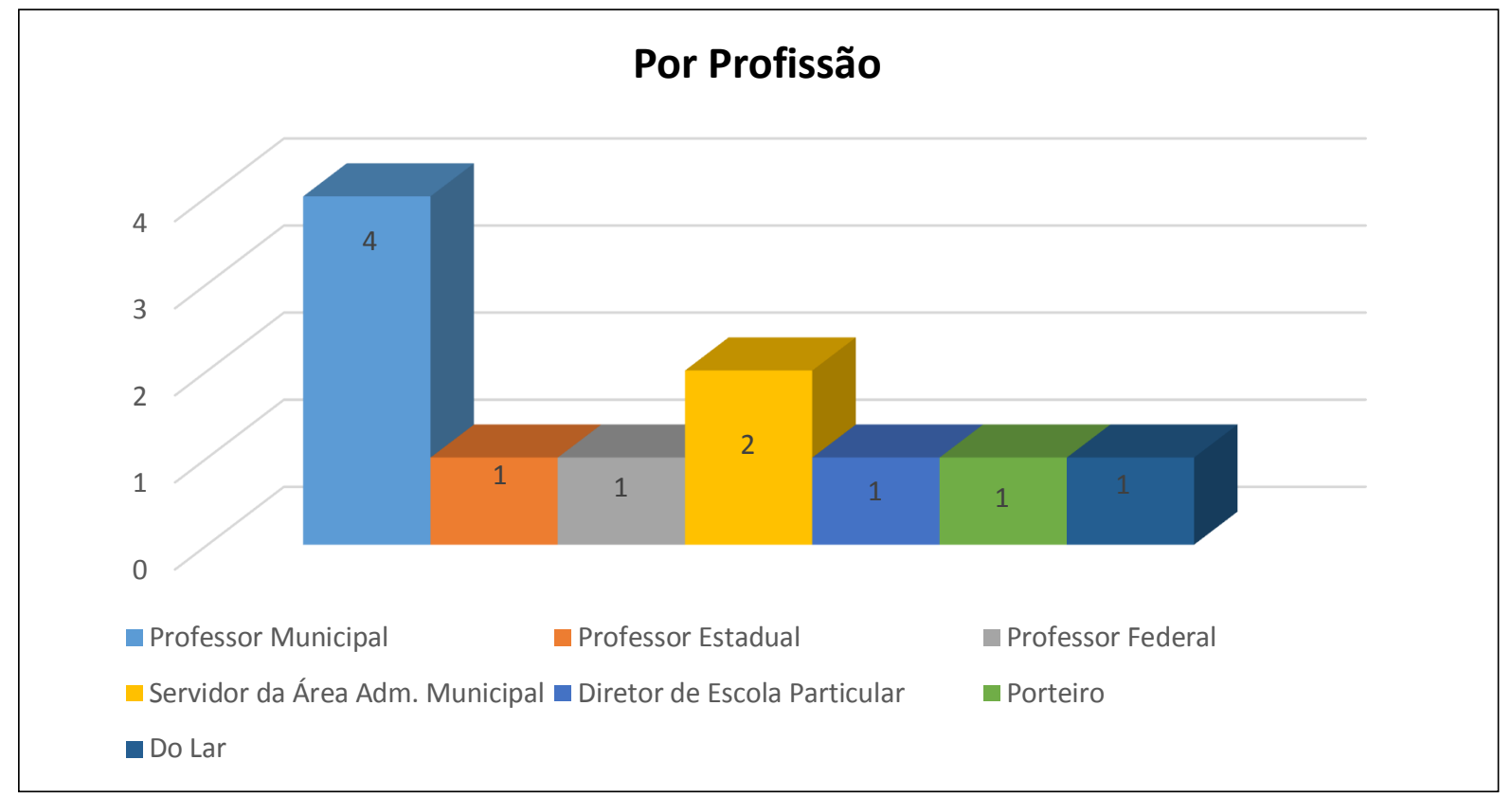

Fonte: Elaboração própria a partir da Pesquisa de Campo.

A representação dos conselheiros em relação ao mercado do trabalho evidenciou uma diversidade no campo profissional, contemplando as seguintes áreas:

- Docência (Esfera Federal);

- Docência (Esfera Estadual);

- Docência (Esfera Municipal);

- Administrativa (Auxiliares Administrativos Municipais);

- Direção de Escola Particular;

- Direção de Escola Municipal.

- Segurança (Portaria de prédios residenciais); e

- Doméstica (mulher chefe de família).

Essa representatividade, de acordo com a Lei Municipal e Regimento Interno do Conselho, possibilita diversos olhares sobre os aspectos educacionais de amplitude da atuação do órgão. As profissões elencadas retratam a representação do Estado (Secretaria Municipal de Educação), da Sociedade Civil (Pais de alunos) e Setor Privado (Escolas Particulares). 
Os representantes das esferas federais e estaduais são convidados para contribuir com o desenvolvimento da educação no município de Luziânia - GO. O referido grupo, considerado como heterogêneo, assegura a diversidade e o pluralismo nas discussões cotidianas no âmbito do Conselho, objetivando o cumprimento do seu papel social numa perspectiva participativa e democrática do controle social.

\subsection{Dados da Pesquisa Empírica}

Com o intuito de compreender a efetividade deliberativa do Conselho Municipal de Educação do Município de Luziânia - GO, realizou-se um estudo conjunto que envolveu, num primeiro momento, a análise da legislação municipal relativa à sua instituição (Lei de Criação e Regimento Interno), a partir da qual se analisaram dados indicativos da participação social e da deliberação para constatação de possível controle social no âmbito do Conselho. Em um segundo momento, procedeu-se a análise das atas das reuniões, elegendo-se aspectos relevantes para a avaliação do seu potencial deliberativo.

Da análise das atas foi verificado que comparecia, em todos os setores representados, a maioria absoluta dos conselheiros. Assim, na primeira apreciação, que mostra a frequência dos membros às reuniões, considerou-se o número total de 11 conselheiros nomeados, buscando avaliar desta totalidade, quantos compareceram às reuniões no período analisado, compreendido de 15 de outubro de 2013 a 15 de abril de 2015, no qual ocorreram 38 reuniões plenárias. Segundo Bardin (1977), a análise dos dados foi realizada sob o prisma da análise temática de conteúdo.

A figura abaixo mostra o resultado: 
GRÁFICO 8 - Representação dos Conselheiros que Compareceram às Reuniões Plenárias

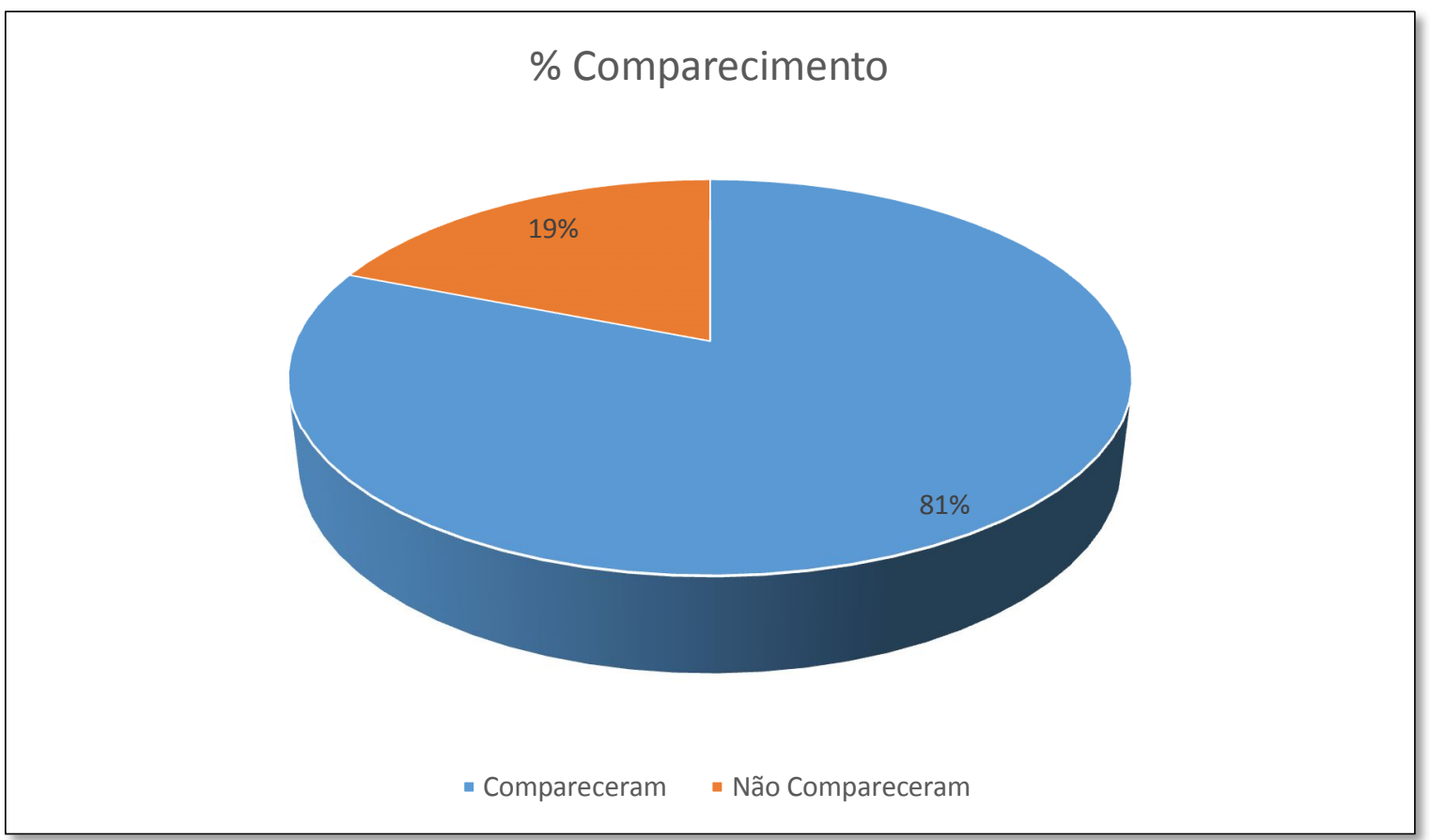

Fonte: Elaboração própria a partir da Pesquisa de Campo.

O quadro retrata uma frequência dos conselheiros relativamente alta, ou seja, $81 \%$ da totalidade dos conselheiros participou da maioria das Reuniões Plenárias ocorridas no período analisado. Os membros infrequentes, na maioria das vezes que precisaram se ausentar das convocações, justificaram as ausências nas Reuniões ocorridas.

QUADRO 1: Frequência dos Conselheiros por Segmento nas Reuniões Plenárias

\begin{tabular}{|c|c|c|c|c|c|}
\hline ATA/Reunião & $\begin{array}{c}\text { Poder } \\
\text { Executivo }\end{array}$ & $\begin{array}{c}\text { Escolas } \\
\text { Particulares }\end{array}$ & Pais de alunos & $\begin{array}{c}\text { Instituições } \\
\text { Públicas } \\
\text { Superiores }\end{array}$ & $\begin{array}{c}\text { Total de } \\
\text { Presentes }\end{array}$ \\
\hline 1 & 4 & 1 & 2 & 2 & 9 \\
\hline 2 & 5 & 1 & 2 & 2 & 10 \\
\hline 3 & 4 & 1 & 2 & 2 & 9 \\
\hline 4 & 4 & 1 & 1 & 2 & 8 \\
\hline 5 & 3 & 1 & 1 & 2 & 7 \\
\hline 6 & 4 & 1 & 2 & 2 & 9 \\
\hline 7 & 4 & 1 & 2 & 2 & 9 \\
\hline
\end{tabular}




\begin{tabular}{|c|c|c|c|c|c|}
\hline 8 & 3 & 1 & 1 & 2 & 7 \\
\hline 9 & 3 & 0 & 2 & 2 & 7 \\
\hline 10 & 4 & 1 & 2 & 2 & 9 \\
\hline 11 & 5 & 1 & 1 & 1 & 8 \\
\hline 12 & 4 & 1 & 1 & 1 & 7 \\
\hline 13 & 4 & 1 & 2 & 1 & 8 \\
\hline 14 & 2 & 1 & 2 & 1 & 6 \\
\hline 15 & 4 & 1 & 2 & 1 & 8 \\
\hline 16 & 2 & 1 & 2 & 2 & 7 \\
\hline 17 & 6 & 1 & 1 & 0 & 8 \\
\hline 18 & 3 & 0 & 1 & 2 & 6 \\
\hline 19 & 4 & 1 & 1 & 2 & 8 \\
\hline 20 & 2 & 0 & 2 & 2 & 6 \\
\hline 21 & 4 & 1 & 2 & 0 & 7 \\
\hline 22 & 4 & 1 & 2 & 1 & 8 \\
\hline 23 & 3 & 1 & 1 & 1 & 6 \\
\hline 24 & 3 & 1 & 1 & 1 & 6 \\
\hline 25 & 3 & 1 & 2 & 1 & 7 \\
\hline 26 & 6 & 1 & 2 & 0 & 9 \\
\hline 27 & 4 & 0 & 2 & 1 & 7 \\
\hline 28 & 2 & 0 & 2 & 2 & 6 \\
\hline 29 & 2 & 1 & 2 & 2 & 7 \\
\hline 30 & 4 & 1 & 1 & 1 & 7 \\
\hline 31 & 3 & 1 & 2 & 2 & 8 \\
\hline 32 & 4 & 1 & 2 & 0 & 7 \\
\hline 33 & 2 & 1 & 1 & 2 & 6 \\
\hline 34 & 3 & 1 & 2 & 2 & 8 \\
\hline 35 & 4 & 1 & 2 & 1 & 8 \\
\hline 36 & 3 & 0 & 1 & 2 & 6 \\
\hline 37 & 3 & 1 & 2 & 1 & 7 \\
\hline 38 & 4 & 1 & 2 & 1 & 8 \\
\hline
\end{tabular}

Fonte: Elaboração própria a partir da Pesquisa de Campo. 
O segundo dado considerado foi o comparecimento dos representantes de cada segmento às reuniões plenárias. Estes números foram obtidos sobre o total de conselheiros presentes em cada reunião no período analisado. De início, procedeu-se ao levantamento do número de conselheiros presentes em cada reunião. Depois, foi feita a classificação dos conselheiros, de acordo com o setor que representavam. Deste modo, obteve-se a quantidade de conselheiros de cada setor que compareceu a cada reunião. Constatou-se maior índice de frequência por parte dos pais de alunos e representantes das escolas particulares nessas reuniões, de acordo com as atas analisadas. Estes dados foram sistematizados conforme quadro acima.

\subsection{Diálogo com os Conselheiros Municipais de Educação e Gestão do IFG}

Com o intuito de decifrar os diversos olhares dos conselheiros Municipais de Educação e do Diretor-Geral do Instituto Federal de Goiás - IFG, Câmpus Luziânia, sobre a relação do CME com o IFG e o que tais atores sociais pensam sobre as perspectivas e desafios da Educação na cidade, foram realizadas 12 entrevistas, sendo11com os conselheiros municipais e 1 com o gestor do IFG (Diretor-Geral).

No diálogo com os entrevistados, foram realizadas oito perguntas que tiveram como foco "como estes vislumbram a importância do Conselho Municipal de Educação de Luziânia", bem como as possíveis interfaces presentes e futuras entre estes e o Câmpus do Instituto Federal de Educação de Goiás na cidade de Luziânia.

As respostas são reveladoras para a análise a que nos propomos, e que se apresentam a seguir. Inquirimos os entrevistados sobre o papel social do CME. Algumas das respostas são transcritas a seguir:

Para o Conselheiro ${ }^{2}$ :

[...]o Conselho é importante e essencial para assegurar a qualidade da Educação na cidade. Vale ressaltar, porém, que o Conselho cumpre apenas parcialmente o seu papel legal de fiscalizador e normatizador. Penso que a sociedade ainda desconhece o devido valor do Conselho. Considero como importante e imprescindível a participação do IFG na representatividade do Conselho e afirmo que nunca pensei na possibilidade de outra Instituição

\footnotetext{
${ }^{2}$ Os entrevistados foram identificados cronologicamente conforme as datas das entrevistas.
} 
substituir o IFG no Conselho. Acho que é muito rico o fato dos conselheiros apresentarem "vários olhares" em prol da Educação. Defendo que a educação deve ser de qualidade e avalio que o Observatório da Educação pode ser a "cereja do bolo" nesta relação do IFG com o CME. Afirmo que"a educação transforma o mundo e as pessoas"(Conselheiro 1).

Dentre as várias questões suscitadas na fala do entrevistado, duas se destacam em nossa opinião: a) o reconhecimento da importância exercida pelo Conselho Municipal de Educação no contexto da realidade local do Município de Luziânia; b) o reconhecimento da importância da participação do IFG no CME.

Se a importância dos Conselhos na gestão das políticas públicas sociaisé reconhecida pela literatura, bem como, pela legislação arrolada que consagram este como espaço de participação popular e controle social numa perspectiva democrática, tal reconhecimento, encontra amparo também nas falas dos agentes sociais envolvidos diretamente na gestão deste órgão, conforme se pode aferir na fala do próximo entrevistado.

O Conselheiro 2 inicia a narrativa com as seguintes reflexões:

[...]o Conselho é importante para o desenvolvimento de Luziânia. Vejo o Conselho com o papel de fiscalizador, normatizador e participativo com a comunidade, num viés democrático. Entendo como essencial e edificante a parceria do IFG com o Conselho considero que o IFG contribui para o sucesso do CME. Analiso que os representantes do IFG trazem conteúdo e fortalecem o espaço do Conselho. Em minha opinião, o IFG contribui para que o CME cumpra o seu papel de Controle Social, assegurando a participação de todos os Conselheiros, de maneira participativa e democrática. Avalio que o IFG, mesmo sendo órgão federal é importante e insubstituível. Avalio ainda positivamente todos os segmentos representados atualmente, sobretudo o IFG e a UEG. Defendo que o Observatório pode ser algo estratégico e excelente para fortalecer a relação do IFG com o CME. Acho fundamental o Conselho ter o Instituto como apoiador e parceiro. Acho que muita gente não conhece o Conselho e desconhece a parceria do CME e o IFG. Entendo que existe um leque de possibilidades com a criação do Observatório e acredito que tal produto técnico apresentado contribuirá com o fortalecimento da parceria do IFG com o CME (Conselheiro 2).

No que se refere à fala do segundo entrevistado, novos elementos são trazidos para o debate sobre o CME, dos quais destacamos: O Conselho Municipal de Educação como espaço de participação popular, contemplado com a diversidade representativa e o Conselho como espaço de exercício da democracia, uma vez que todos os conselheiros têm vez, voz e voto equânime.

Em sua fala, o Conselheiro 11, 
[...]justifico a minha experiência como conselheiro foi relativamente curta, pois estive pouco tempo vinculado ao Conselho. Entretanto, afirmo que durante o período atuando como Conselheiro, identifiquei certo controle da Prefeitura sobre as ações desenvolvidas pelo órgão. Ressaltoque percebi no período experimentado como Conselheiro que havia grande demanda de diversas formas para avaliação e parecer do Conselho. Defendo a participação do IFG no Conselho, mas ressalto a dificuldade dos servidores se dedicarem com afinco às atividades. Penso que $o$ fato de muitos servidores do IFG morarem em outros municípios e no DF dificulta a participação mais efetiva no Conselho. Considero a criação do Observatório de fundamental importância para a cidade de Luziânia (Conselheiro 11).

Analisando os conteúdos da fala do representante identificado como Conselheiro 11, é perceptível a preocupação do mesmo no que se refere à efetividade da representação, considerando as demandas complexas que advém do Conselho. Ele destaca ainda a relevância do Conselho para assegurar a qualidade da educação no município e aponta o Observatório como fundamental para consolidar a relação do CME com o IFG e definir novos rumos para a educação na cidade de Luziânia.

Sob esta perspectiva, em sua entrevista o Gestor do IFG relata que:

[...] resido em Luziânia e que atuei como Conselheiro no período de março a agosto de 2011. Trabalho como Professor no IFG há 6 anos. Sou responsável pela organização e condução das ações institucionais desenvolvidas no Câmpus, em conformidade com as políticas educacionais definidas pela Reitoria. Avalio que o Conselho cumpre o seu papel e que incentiva e trabalha pela melhoria da qualidade do ensino em Luziânia, buscando garantir uma educação mais justa e igualitária, o que contribui para que a sociedade se torne mais inclusiva e preocupada com a formação das crianças e jovens do município, visando torná-los bons cidadãos. Acredito que a participação do IFG no Conselho é muito importante, pois permite que a composição desse Conselho seja mais democrática e dinâmica, proporcionando um diálogo entre diferentes instituições educacionais e a sociedade civil, além de permitir uma participação efetiva nas discussões e questões voltadas ao fortalecimento da educação em Luziânia. Destaco ainda que o IFG contribui para que o Conselho cumpra o seu papel, tendo participação efetiva nas discussões e decisões tomadas no âmbito do Conselho. Aponto o compromisso com a justiça social, equidade, cidadania, ética, preservação do meio ambiente, transparência e gestão democrática como norteadores da relação do IFG com o Conselho, onde destaco ainda o compromisso do IFG com o ensino integrado, pesquisa e extensão; compromisso com a formação integral do cidadão, com a produção e difusão do conhecimento científico e tecnológico e finalmente o compromisso com a educação inclusiva e emancipatória, com a oferta de formação profissional, com a promoção do desenvolvimento sociocultural, estando sempre atento à organização produtiva, ao potencial regional, à cultura e às necessidades e expectativas do cidadão. Em relação ao Observatório da Educação, avalio que se o mesmo estiver dentro das exigências legais, não faço óbice à vinculação do mesmo ao sítio do IFG, apoiando a iniciativa ora proposta (Gestor do IFG). 
Na sequência da análise de representantes do Instituto Federal de Goiás - IFG, Câmpus Luziânia, extraímos da fala do Diretor-Geral, aqui denominado Gestor, algumas reflexões interessantes para avançarmos na compreensão da relação do CME com o IFG. O mesmo se mostra conhecedor da importância do Conselho, no controle social e como fomento à participação democrática, uma vez que foi membro deste Conselho. Destaca ainda em sua fala o compromisso do IFG com a educação local, visando a promoção, produção e difusão do conhecimento numa perspectiva de educação inclusiva. Apoia a criação do Observatório e se compromete a continuar não medindo esforços na contribuição para o aprimoramento contínuo a parceria do IFG com o Conselho Municipal de Educação na cidade, inclusive disponibilizando o sítio do IFG como possível local para instalação do Observatório da Educação na cidade.

Na fala do Conselheiro 5, destaca-se:

[...] defendo a tese que o Conselho tem a função de fomentar a Educação infantil no município. Considero o Conselho como participativo e democrático. Avalio o Conselho como ponte entre a sociedade e o poder público e vejo positivamente a participação do IFG no Conselho. Considero o representante do IFG como inteligente e engajado politicamente e penso que o IFG agrega conhecimento e ideias para respaldar a tomada de decisões no Conselho. [...] o IFG, por ser órgão federal, agrega valor e status ao Conselho. O IFG contribui também para que o Conselho cumpra o seu papel de controle social. Esta contribuição se dá pela representatividade positiva do IFG, principalmente nas reuniões plenárias. Acho que o Instituto contribui para o sucesso do Conselho em Luziânia e que não há outra Instituição que poderia substituí-lo com a mesma eficácia. [...] a criação do Observatório daria mais visibilidade ao Conselho e a todos os esforços desenvolvidos em prol da educação em Luziânia. Penso que o IFG e o Conselho, apesar dos avanços, poderiam interagir mais, fazer mais eventos conjuntos, otimizando recursos humanos, materiais e financeiros da Prefeitura Municipal de Luziânia e do Governo Federal (Conselheiro 5).

Podemos extrair da fala do Conselheiro 5, as seguintes reflexões: Considera o IFG como parceiro estratégico para que o CME cumpra o seu papel de controle social, com viés participativo e democrático. Analisa que apesar dos avanços, tanto o CME como o IFG poderiam contribuir mais para a consolidação da qualidade da educação no município. Destaca que o Observatório poderia possibilitar maior visibilidade aos trabalhos desenvolvidos pelo Conselho.

O Conselheiro 4, relata que: 
[...] o Conselho deve verificar a situação legal das Instituições Escolares de acordo com a LDB e demais legislações municipais e estaduais. [...] O Conselho funciona como normatizador da Educação Municipal. Avalio positivamente a participação do IFG no Conselho. Penso que sempre se pode aprimorar mais a relação do IFG com o CME. Ressalto que representantes do IFG já tiveram papéis fundamentais em situações de conflitos escolares. Destaco que o IFG contribui para que o Conselho cumpra o seu papel de controle social e que tal contribuição se dá pela representatividade positiva do IFG, principalmente nas reuniões plenárias e na análise de documentos do Conselho. Avalio que o IFG é importante para o desenvolvimento da educação em Luziânia e que não vejo outra Instituição que poderia substituílo com a mesma eficiência e eficácia. A criação do Observatório da Educação dará mais visibilidade ao Conselho e será um canal importante de comunicação com a população do município [...] penso que o IFG e o Conselho, apesar das conquistas, podem e devem se esforçarem mais para que a Educação em Luziânia atinja seus objetivos de transformação da sociedade.A cada reunião e desafio enfrentado, avalio que muita coisa já foi feita e há muita coisa ainda pra ser realizada, juntos, CME e IFG (Conselheiro 4).

Os dados extraídos da fala do entrevistado, aqui identificado como Conselheiro 4, foram consistentes e significativos. O mesmo demonstrou muita segurança ao ser inquirido sobre a relação do Conselho com o IFG.Pode-se destacar desta fala, a importância do Conselho no cumprimento da sua função normatizadora da Educação Municipal. Constata-se também que ele valoriza a participação do IFG no Conselho e que tem interesse em contribuir com a criação do Observatório da Educação, objetivando dar maior visibilidade aos trabalhos do CME e do IFG, em prol da educação local e regional.

O Conselheiro 9, aponta que:

[...] no Conselho Municipal de Educação, atuo como Conselheiro há aproximadamente 4 anos, sendo o mais antigo da atual gestão. Ressalto que nunca quis ser presidente deste Conselho. [...] sugiro que é necessário verificar a situação legal das Instituições educacionais na cidade e avalio que o Conselho cumpre o papel fiscalizador. Acho que o Conselho poderia ser mais rígido com as escolas irregulares e ressalto que falta reconhecimento do Conselho por parte da sociedade e do Poder Público. Analiso que o Conselho é muito burocrático e que em algumas situações, pouco efetivo. Avalio positivamente a participação do IFG no Conselho e penso que o Instituto contribui para que o Conselho cumpra o seu papel de controle social. Defendo que tal contribuição se dá pela representatividade positiva e efetiva do IFG, através do seu representante. Avalio que o IFG é importante para o desenvolvimento da educação em Luziânia e que não consigo visualizar outra Instituição que poderia substituir o Conselho com a mesma competência. Defendo a criação do Observatório da Educação como algo imprescindível para consolidar a relação do IFG com o CME no município (Conselheiro 9). 
A fala do Conselheiro 9 evidencia a hipótese inicial dessa pesquisa, que procurou no decorrer do estudo científico, avaliar se a relação do Conselho Municipal de Educação com o Instituto Federal de Goiás em Luziânia - GO é produtiva, contribuindo para que o Conselho cumpra o seu papel social, pautado em valores éticos, participativos e democráticos. Destacamos aqui a avaliação positiva que o mesmo destaca nesta relação, compreendendo que o IFG de fato contribui com o CME e com a sua missão de defesa da educação de qualidade no município, apontando o Observatório como crucial na consolidação desta linha de trabalho. Vale ressaltar ainda que o referido conselheiro critica o excesso de burocracia do Conselho e defende maior rigor do referido órgão frente às irregularidades encontradas no seu cotidiano.

O Conselheiro 8 faz o seguinte relato:

[...] na minha maneira de pensar, ao ser indagado sobre o papel do Conselho, avalio que o mesmo cumpre um papel de fiscalizador da Educação Municipal. Quando fui nomeado, fiquei receoso, pensando como seria a receptividade aqui no Conselho. Após esses 18 meses, avalio o quanto venho aprendendo, principalmente nos momentos de debates nas reuniões, que sempre me esforço para não perder. [...] avalio como positiva a relação do IFG com o Conselho... São vários olhares em busca do consenso, o que não é fácil. [...] penso que o IFG é indispensável no Conselho e acho que não poderia jamais ser substituído... Muita gente na cidade não conhece nem o Conselho nem o IFG. Neste caso, o Observatório da Educação poderia contribuir para divulgar o bonito trabalho desenvolvido tanto pelo Conselho como pelo Instituto. O Conselho precisa ser menos burocrático e mais efetivo. Como Conselheiro, sempre ouço reclamações dos pais e professores em relação a algumas decisões tomadas no âmbito Conselho (Conselheiro 8).

A fala do entrevistado acima, identificado como Conselheiro 8, evidencia que os desafios da educação no município de Luziânia são bastante complexos. De maneira bem simples e objetiva, o mesmo, que concluiu o ensino médio a pouco tempo, na modalidade de Jovens e Adultos (EJA), demonstrou capacidade de compreensão, advinda da sabedoria popular, uma vez que nem sempre, as pessoas com formação em nível superior, são capazes de demonstrar um grau de politização e de análise crítica tão assertivo, sobretudo neste estudo.

Todas as falas dos entrevistados e das entrevistadas foram unânimes em relação aos pontos positivos da relação do Conselho Municipal de Educação com o Instituto Federal de Goiás - IFG, no município de Luziânia - Goiás. 
Para o Conselheiro 10, ocupante da cadeira destinada aos Pais dos alunos, a educação em Luziânia, a partir da relação entre o Conselho e o IFG, pode ser aprimorada:

[...] destaco que apesar de pouca escolaridade, valorizo a educação dos meus filhos nas escolas municipais da cidade de Luziânia. Penso que a educação de qualidade é construída com a participação de toda a sociedade, por isso, aceitei ser Conselheiro Municipal de Educação. Avalio que as escolas deveriam dialogar mais com o Conselho, unindo forças para melhorar o ensino na cidade. (Conselheiro 10).

Para ilustrar as falas dos entrevistados, segue abaixo dois quadros, destacando a análise de conteúdo dos Conselheiros Municipais e do Diretor-Geral do IFG - Câmpus Luziânia, respectivamente.

\section{Quadro 2: Análise de Conteúdo - Conselheiros Municipais de Educação}

\begin{tabular}{|c|c|c|}
\hline Categoria & Subcategoria & Verbalização \\
\hline $\begin{array}{l}\text { 1. Observatório da } \\
\text { Educação }\end{array}$ & História de Luziânia & $\begin{array}{l}\text { "Acho importante a criação do Observatório } \\
\text { da Educação em Luziânia para divulgar de } \\
\text { forma crítica e acessível a história da cidade". } \\
\text { "O Observatório da Educação, além de } \\
\text { contemplar a divulgação da história de } \\
\text { Luziânia, será um mecanismo importante para } \\
\text { apoiar o desenvolvimento da Educação na } \\
\text { cidade". } \\
\text { "Enquanto representante do Conselho, tenho } \\
\text { interesse em contribuir com a criação do } \\
\text { Observatório da Educação, objetivando dar } \\
\text { maior visibilidade aos trabalhos do CME e do } \\
\text { IFG, em prol da educação local e regional". }\end{array}$ \\
\hline $\begin{array}{l}\text { 2. Participação do } \\
\text { IFG no CME }\end{array}$ & $\begin{array}{l}\text { Qualidade da relação } \\
\text { IFG e CME }\end{array}$ & $\begin{array}{l}\text { "Avalio a participação do Instituto Federal de } \\
\text { Goiás no Conselho Municipal de Educação } \\
\text { como positiva. Não consigo vislumbrar outra } \\
\text { Instituição substituindo o IFG no cotidiano das } \\
\text { atividades do CME". } \\
\text { "Considero o IFG como parceiro estratégico } \\
\text { para que o CME cumpra o seu papel de } \\
\text { controle social, com viés participativo e } \\
\text { democrático. Analiso que apesar dos avanços, } \\
\text { tanto o CME como o IFG poderiam contribuir } \\
\text { mais para a consolidação da qualidade da } \\
\text { educação no município". } \\
\text { "Avalio como positiva a relação do IFG com o } \\
\text { Conselho. Penso que são vários olhares em } \\
\text { busca do consenso, o que não é fácil. Penso } \\
\text { que o IFG é indispensável no Conselho e acho } \\
\text { que não poderia jamais ser substituído". }\end{array}$ \\
\hline
\end{tabular}




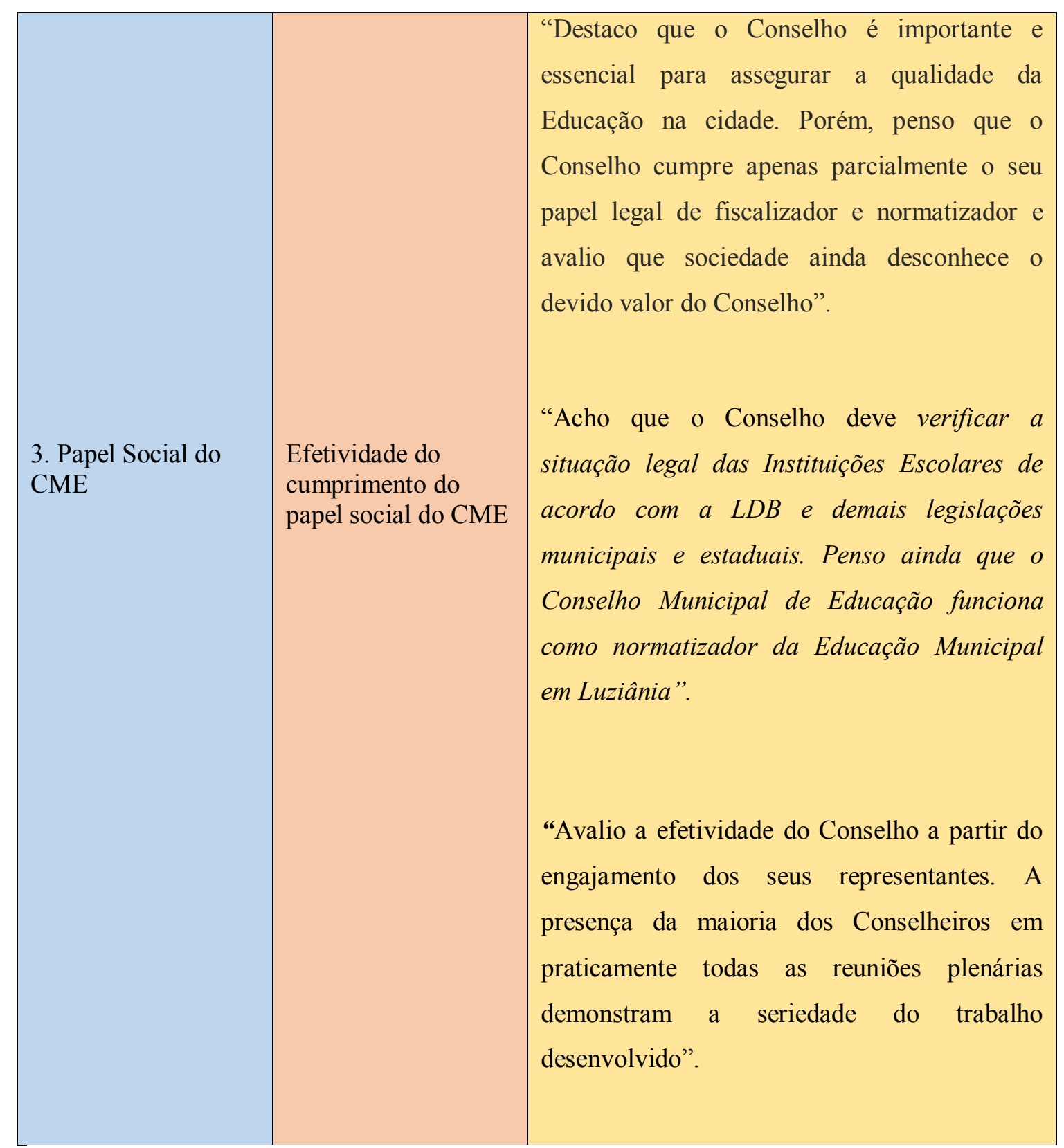

Fonte: Elaboração própria a partir da Pesquisa de Campo. 
Quadro 3: Análise de Conteúdo - Diretor-Geral do IFG

\begin{tabular}{|c|c|c|}
\hline Categoria & Subcategoria & Verbalização \\
\hline 1. Observatório da Educação & História de Luziânia & $\begin{array}{l}\text { "Em relação a criação do } \\
\text { Observatório da Educação } \\
\text { defendo que se o mesmo } \\
\text { estiver dentro das exigências } \\
\text { legais, não faço óbice à } \\
\text { vinculação do mesmo ao sítio } \\
\text { do IFG, pois em Luziânia } \\
\text { precisamos unir forças para } \\
\text { aprimorar a qualidade da } \\
\text { Educação ofertada". }\end{array}$ \\
\hline $\begin{array}{l}\text { 2. Participação do IFG no } \\
\text { CME }\end{array}$ & $\begin{array}{l}\text { Qualidade da relação IFG e } \\
\text { CME }\end{array}$ & $\begin{array}{l}\text { "Acredito que a participação } \\
\text { do IFG no Conselho é muito } \\
\text { importante, pois permite que a } \\
\text { composição desse Conselho } \\
\text { seja mais democrática e } \\
\text { dinâmica, proporcionando um } \\
\text { diálogo entre diferentes } \\
\text { instituições educacionais e a } \\
\text { sociedade civil, além de } \\
\text { permitir uma participação } \\
\text { efetiva nas discussões e } \\
\text { questões voltadas ao } \\
\text { fortalecimento da educação em } \\
\text { Luziânia". Acho que o IFG } \\
\text { contribui para que o Conselho } \\
\text { cumpra o seu papel, tendo } \\
\text { participação efetiva nas } \\
\text { discussões e decisões tomadas } \\
\text { no âmbito do Conselho". }\end{array}$ \\
\hline 3. Papel Social do CME & $\begin{array}{l}\text { Efetividade do cumprimento } \\
\text { do papel social do CME }\end{array}$ & $\begin{array}{l}\text { "Vejo no Conselho o } \\
\text { compromisso com a justiça } \\
\text { social, equidade, cidadania, } \\
\text { ética, preservação do meio } \\
\text { ambiente, transparência e } \\
\text { gestão democrática como } \\
\text { norteadores da luta incessante } \\
\text { pela qualidade de educação no } \\
\text { município de Luziânia". }\end{array}$ \\
\hline
\end{tabular}

Fonte: Elaboração própria a partir da Pesquisa de Campo. 


\section{Capítulo IV - Ferramenta de Aplicabilidade Social - Produto Técnico}

\subsection{Observatório da Educação em Luziânia - GO}

O presente capítulo dessa dissertação tratará da proposição do Produto Técnico, derivado da revisão teórica e da pesquisa realizada na proposta de intervenção na realidade. Propomos aqui a ferramenta de criação de um Observatório da Educação em Luziânia - GO, com ênfase na publicização da história da cidade e dos trabalhos desenvolvidos pelo Conselho Municipal de Educação, em parceria com o IFG local. O Observatório poderá se difundido através de encontros temáticos, artístico-culturais no Instituto Federal de Goiás - IFG (Câmpus Luziânia) e em escolas públicas e privadas, visando maior interlocução entre os diversos segmentos sociais da cidade. A mídia local, impressa e falada, será também utilizada no decorrer da implantação desta ferramenta de aplicabilidade social.

Tal iniciativa traz no cerne a ideia de contribuir para o desenvolvimento local, visando, através da descentralização na implantação, suporte e manutenção do Observatório da Educação, a exemplo do Observatório do IFG, localizado na Reitoria, que se constitui na criação de sistemas de informação como estratégia de expansão, modernização e melhoria contínua da Educação Profissional e Tecnológica (EPT), tanto ao nível das unidades acadêmicas, que oferecem essa modalidade de educação, como ao nível das instâncias de regulação e avaliação, como é o caso da Secretaria de Educação Profissional e Tecnológica do Ministério da Educação (SETEC/MEC), tendo em vista subsidiar os processos de planejamento estratégico e operacional, bem como suas rotinas administrativas, acadêmicas e de gestão, estabelecendo os indicadores necessários ao diagnóstico, monitoramento e avaliação.

A implantação do Observatório da Educação objetiva democratizar e disponibilizar informações e análises que serão utilizadas na definição de políticas públicas de expansão da educação local, em consonância com o Conselho Municipal de Educação em Luziânia, bem como se constituir em um instrumento para a busca da eficácia dos programas e projetos de educação. 
O Observatório da Educação, além de tratar das questões mais específicas no âmbito municipal, visa alinhar a Educação Profissional e Tecnológica com as Políticas Públicas de desenvolvimento, geração de trabalho e renda e de Educação de Jovens e Adultos (EJA). Visa ainda promover a Educação Profissional e Tecnológica associando-a a um projeto de desenvolvimento socioeconômico, no município e região. Propõe-se que o Observatório da Educação funcione como um Portal (virtual e interativo), agrupando as informações sobre a educação e sua relação intrínseca ao mundo do trabalho na regional.

Nesse sentido, torna-se necessário para a criação física do Observatório da Educação, disponibilidade de sala com equipamentos multimídia e equipe mínima composta por um profissional com nível superior e outro servidor com nível de ensino médio para o início imediato dos trabalhos, previsto para o dia 15 de dezembro de 2015, conforme documentos em anexo. Endossando este produto técnico, de aplicabilidade social, conta-se, com o apoio da Reitoria do IFG e Coordenação do Observatório do Mundo do Trabalho (ambas sediadas em Goiânia-GO), além do compromisso de apoio irrestrito pactuado com a direção-geral do Câmpus Luziânia - GO.

Vale ressaltar que as políticas públicas educacionais de forma geral, e no campo particular, as políticas públicas voltadas para a educação profissional e o ensino tecnológico, tem vivenciado transformações significativas nos últimos 12 anos (2003-2015), sendo que estas provocaram mudanças substanciais na organização desta modalidade de ensino, com vistas à redefinição da sua identidade institucional, perfil de egresso, impacto no mercado de trabalho, dentre outros. Na contemporaneidade, torna-se cada vez mais necessário, pensar em promover atividades que possam assegurar que a família participe efetivamente do cotidiano dos seus filhos no ambiente escolar, contribuindo com professores, educadores, direção, supervisão, serviços gerais e toda a comunidade escolar no árduo desafio de reinventar a Educação aprimorando metodologias que extrapolem as salas de aulas e os muros da escola.

O Observatório da Educação possibilitará a utilização de instrumentos normativos das Políticas Públicas de Educação como ferramentas substanciais na mobilização social e nos debates que se pretendem empreender. Com a participação dos discentes, docentes, técnicos administrativos e comunidade em geral, o Observatório contemplará a difusão da história da cidade de Luziânia no decorrer destes seus 268 anos de existência, história esta, reconstruída de maneira crítica, com as experiências do cotidiano, sugerindo desta maneira os conteúdos que veicularão nos sites do Instituto Federal de Goiás e da Prefeitura Municipal, no intento de romper o preconceito e debater sobre os fenômenos da pobreza e violência que 
historicamente, permeiam a desigualdade social no país. Além disso, assuntos inerentes à educação serão contemplados nesta proposta interventiva.

Os principais desafios identificados, que justificam esta ação inovadora e de caráter contínuo, consistem na necessidade da comunidade escolar se unir, visando buscar estratégias de maior compreensão das políticas públicas, com enfoque na Educação. Ao enfrentar a distância atual, que caracteriza as relações entre escola e comunidade pressupõe-se a ampliação da dimensão das experiências educacionais na vida dos estudantes, promovendo a qualificação da educação pública vivenciada em âmbito local. Para isso, as diversas experiências comunitárias precisam estar articuladas aos principais desafios enfrentados por estudantes e professores. Quando a escola compartilha a sua responsabilidade pela educação, ela não perde seu papel de protagonista, porque sua ação é necessária e insubstituível, porém, não dispensa a participação dos demais atores sociais, como a comunidade e a família.

Conforme Thales Novaes de Andrade (2006) a inovação educativa, por sua vez, vem sendo pesquisada como tema relevante especialmente em países como os Estados Unidos, Canadá, Espanha e Portugal. Além disso, uma aproximação superficial à inovação educativa pode ser identificada como dimensão técnica, porém, envolve também dimensões política e cultural relativas aos processos educacionais.

O Observatório da Educação, visa promover maior interlocução entre o Conselho Municipal de Educação com o Instituto Federal de Goiás, envolvendo as escolas públicas e privadas, localizadas no município de Luziânia. Nos encontros temáticos para proposição e criação dessa ferramenta, pretende-se utilizar estratégias de mobilização cultural (música, teatro, dança, etc.), objetivando contribuir para maior formação política, onde os atores envolvidos devem participar efetivamente, protagonizando todo o processo de criação, implementação e desenvolvimento do Observatório. Tal iniciativa busca, ainda, estimular o exercício da cidadania, contribuir para o aprimoramento contínuo da qualidade da educação e consequentemente, melhoria da vida em comunidade, com oferta de serviços na saúde, educação, comércio, habitação, dentre outras áreas que dialogam com o cotidiano das pessoas.

O Apoio do Poder Público é algo em construção, principalmente nos espaços do IFG e do Conselho Municipal de Educação, cuja relação está sendo pesquisada neste estudo do Mestrado Profissional em Educação. Tal iniciativa de se difundir a educação se faz necessária pelo fato do município de Luziânia encontrar-se situado na Região do entorno sul do Distrito Federal e compor a Região Integrada de Desenvolvimento do Distrito Federal e 
Entorno (RIDE), constituída pelo Distrito Federal (Brasília) e mais 19 municípios de Goiás (BRASIL, 2011).

De acordo com as informações do Instituto Brasileiro de Geografia e Estatística (IBGE) e do Observatório do Mundo do Trabalho do IFG, o município de Luziânia encontrase na área de maior concentração demográfica da RIDE, apresentando problemas sociais como: precariedade de moradia e violência, sendo que a população da cidade é composta essencialmente por pessoas oriundas de outros estados, caracterizados como pessoas em situação de vulnerabilidade social, com renda familiar média abaixo de dois salários mínimos vigentes.

Destarte, outros elementos que sustentam a necessidade de tal intervenção são pautados no distanciamento entre professores e técnicos Administrativos no IFG, onde ações promovidas na Instituição ainda são bem polarizadas, apesar do esforço de alguns profissionais em quebrar essas barreiras "invisíveis". Na experiência do Conselho Municipal de Educação em Luziânia, apesar dos avanços, ainda enfrentamos problemas no que tange a gestão das escolas municipais, com diretorias autoritárias, inibindo maior participação dos corpos docente e discente na tomada de decisões do cotidiano educacional. Tais conflitos muitas vezes têm sido objetos de intervenção do Conselho Municipal de Educação, com êxito, nas perspectivas de mediação dos conflitos e fortalecimento dos Conselhos Escolares.

A avaliação do presente projeto interventivo está ocorrendo em todas as fases, desde seu início com os contatos e sensibilização dos parceiros e atores envolvidos até a execução propriamente dita, que ocorrerá dentro das Unidades Escolares e do IFG, com previsão de início em meados de dezembro de 2015. Neste momento, que antecede a fase de implantação, está sendo verificada a aceitação do projeto pelo público-alvo. Quanto às demais metas, serão observadas de forma contínua e após a sua execução, verificando-se assim o cumprimento do que está sendo proposto. Os atores sociais envolvidos serão monitorados durante todo o projeto, através da observação do interesse, participações orais, escritas e práticas. Os participantes terão sempre oportunidades de sugerirem alterações que se fizerem necessárias neste processo, assumindo o protagonismo em todas as etapas.

O Observatório da Educação terá também como meta promover a formação continuada dos conselheiros municipais de Educação, visando aprimorar os debates sobre a política pública e como as pessoas e instituições educacionais em Luziânia poderão contribuir 
para que a qualidade do sistema educacional seja alcançada em sua plenitude, na relação de ensino-aprendizagem e nos prazos determinados entre as partes envolvidas.

O presente produto técnico buscará contribuir para possível transformação social, sobretudo nos ambientes educacionais (principalmente escolas públicas e IFG), que receberão as palestras temáticas difundindo o Observatório da Educação, onde a participação efetiva de toda a comunidade será imprescindível para obtenção dos objetivos propostos. A Educação Tecnológica e Profissional. Os grupos artísticos do IFG poderão divulgar os trabalhos no Observatório. Cada grupo ficará responsável em atualizar as informações no site. Essa descentralização das responsabilidades de atualização será partilhada também pelo Conselho Municipal de Educação e por pessoas responsáveis com a história e informações atuais da cidade de Luziânia - GO.

Nesse contexto torna-se imperativo a proposição de estratégias de enfrentamento aos ajustes neoliberais, investindo na formação continuada, na politização dos atores sociais envolvidos e no fortalecimento dos Conselhos, a exemplo do Conselho Municipal de Educação da cidade de Luziânia, lócus desta pesquisa.

Conclui-se que a criação do Observatório da Educação visa contribuir para aumentar os índices de participação dos alunos e comunidade nos assuntos educacionais, sensibilizando ainda gestores, professores, conselheiros municipais, assistentes sociais, pedagogos, psicólogos, discentes, dentre outros, em todas as atividades inerentes ao desenvolvimento local, com ênfase na Política Pública de Educação, em interface com as demais Políticas, sobretudo, Saúde e Assistência Social. Este engajamento dos diversos segmentos sociais é fundamental para que a democracia seja efetivada através da participação popular e do controle social. O diagnóstico, a avaliação e o monitoramento são ferramentas norteadoras neste processo, onde se pretende evidenciar e constatar como se materializa a força da participação, tendo principalmente o IFG e as escolas como lócus investigativo e interventivo. 


\section{Considerações finais}

O trabalho investigativo, desenvolvido nesta pesquisa, após todo o processo percorrido alinhando experiências teóricas e empíricas, aponta algumas considerações. A hipótese versava sobre a participação do Instituto Federal de Goiás no âmbito do Conselho Municipal de Educação em Luziânia - GO. Tal participação se expressa em empoderamento e protagonismo como contribuição para a realização da função social do Conselho. Dessa maneira, independente da participação deliberativa do Instituto no âmbito do Conselho Municipal de Educação, até o presente momento, a proposta do Observatório da Educação, se constitui como mais um viés de manifestação de esforço para que o papel social do Conselho seja cumprido com efetividade e eficácia.

As respostas dos entrevistados evidenciaram que a relação do Conselho Municipal de Educação com o Instituto Federal de Goiás, no município de Luziânia (Goiás) se constitui em algo positivo, que contribui diretamente para o desenvolvimento das potencialidades da educação em níveis local e regional. Ressalta-se ainda que tanto as entrevistas como a análise documental das atas e demais instrumentos normativos sugeriram que o Conselho Municipal de Educação cumpre o seu papel de controle social e possibilita aos conselheiros vivenciarem e reproduzirem práticas democráticas e participativas, ainda que enfrentando adversidades, a exemplo da ausência de representantes dos Movimentos Sociais nos assentos do referido Conselho.

Do ponto de vista teórico, a promulgação da Constituição Federal de 1988 se apresenta como marco e divisor de águas, uma vez que a carta magna veio materializar todos os esforços dos diversos segmentos sociais após o período ditatorial (1964 a 1985), onde vale destacar a priori o processo de redemocratização, definindo diretrizes demarcadas por aspectos democráticos, na perspectiva de garantias de direitos sociais, políticos e civis.

A retomada da trajetória histórica dos movimentos sociais no Brasil foi permeada por lutas, avanços e retrocessos, sobretudo no período de 1970 a 2000, contemplando a transição da Ditadura Militar para a abertura democrática, com início em 1985, com as Diretas Já e preparação para a conquista histórica da Constituição Federal de 1988. As contradições foram uma constante na análise do desenvolvimento do país, desde a teoria do bolo, criada por Delfim Neto na década de 60, com a promessa que o bolo deveria crescer para depois ser dividido com toda a população, o que se caracterizou como um engodo 
histórico, uma vez que as desigualdades sociais foram ficando cada vez mais complexas, muitas vezes, com novas roupagens, apresentando novas expressões da questão social, seja pela expansão do capitalismo e pela manifestação da pobreza e exclusão social, seja pela luta de participação no mundo capitalista do consumo, reivindicando leis, direitos e acessos múltiplos.

Para entendermos todo o processo vivenciado pela Educação no Brasil, além da Constituição Federal, chamada de Constituição Cidadã, ressalta-se neste estudo, também a importância da Lei de Diretrizes e Bases da Educação - LDB, que garantiram a concepção da Educação como Política Pública, pautadas na concepção de direito do cidadão e dever do Estado, o que faz toda a diferença na formulação e implementação de políticas públicas sociais.

Apesar das dificuldades encontradas quanto à análise da relação do Conselho Municipal de Educação e o Instituto Federal localizado em Luziânia, foi possível alcançar objetivos como: descrever os fatores de contribuição do citado Instituto para com o Conselho; contextualizar a história do município de Luziânia na constituição do Conselho (Gestão 20132015) e a presença do Instituto neste período; e desenvolver um plano de trabalho de um Observatório de Educação, constituindo mais um reforço que visa a contribuir para a efetivação da função pública do Conselho.

Outro ponto a se destacar na análise das falas dos entrevistados, apesar de mais de $80 \%$ dos Conselheiros apresentarem graus de instrução que variam do nível superior de graduações e especializações diversas até o Mestrado, é a lacuna existente pela ausência de formação continuada para exercício do papel de debater e aprimorar as políticas públicas educacionais em nível municipal, que é latente. Tal cenário adverso justifica ainda mais a importância da criação do Observatório da Educação, que dentre outras funções, será também utilizado para fomentar a democratização do acesso às informações e formação continuada dos atores sociais envolvidos.

Em relação aos desafios atuais da Educação e da Educação Profissional e Tecnológica, a pesquisa dialoga com o educador Paulo Freire, que sempre defendeu que "Não há saber mais ou saber menos. Há saberes diferentes". Tal afirmativa de Freire reitera com a impressão extraída principalmente das entrevistas com os Conselheiros Municipais de Educação. Todos os representantes, independente da formação acadêmica, em suas falas, demonstraram engajamento e compreensão política da realidade da educação em Luziânia, destacando limites e potencialidades deste cenário analisado. 
Outra constatação, após estudos sobre a educação profissional e tecnológica, consiste no fato que essa modalidade se encontra em posição estratégica para o desenvolvimento sustentável do Brasil. Destarte, defendemos que a EPT, além de assumir a desafiadora missão de formadora de mão-de-obra para o mercado de trabalho, deve também assegurar a democratização do acesso de estudantes de todas as idades e classes sociais, numa perspectiva pautada em valores éticos e humanos, possibilitando que a Educação, em toda a sua amplitude, cumpra o seu papel transformador da sociedade, seguindo preceitos da cidadania e da dignidade humana, conforme preconiza a Constituição Federal de 1988 e demais legislações vigentes inerentes a esta temática.

Vale ressaltar que todos os dados, estudos e reflexões advindos da produção dessa dissertação não serão suficientemente capazes de proporcionar respostas concretas às inquietações e angústias, naturais nestes processos científicos permeados por contradições extraídas da realidade vivenciada e pesquisada. Serão sempre válidas as proposições de novas pesquisas que dialoguem com os temas abordados neste estudo e que, possivelmente, suprirão com mais eficácia as lacunas desta primeira experiência, onde entrevistas, atas e demais documentos facultaram parcialmente algumas considerações, aqui conceituadas, simplesmente, como inconclusas. A leitura de autores que pesquisaram temas afetos foi imprescindível para conhecer alguns trabalhos que dialogam com a dissertação, uma vez que analisar o papel e efetividade dos Conselhos Municipais tem contribuído para a consolidação das políticas públicas brasileiras.

A pesquisa sobre a relação do Conselho Municipal de Educação (CME) com o Instituto Federal de Goiás (IFG) teve como propósito esse percurso a busca incessante de conhecimento da realidade vivenciada em Luziânia - Goiás pelos atores sociais que protagonizaram o presente estudo científico. Os esforços no intuito de apreensão dos movimentos contraditórios e dinamizados foram uma constante. Com a impressão de leituras aproximadas da realidade, sem pretensões exacerbadas de conclusões definitivas, parte-se do pressuposto que o conhecimento é reproduzido mentalmente, fruto de diversos exercícios reflexivos e do movimento real. Dessa maneira, sugere-se algumas análises e respostas às perguntas que nortearam este trabalho, sem desconsiderar que o conhecimento do objeto demarcado pelo sujeito sofrer as influências desse sujeito.

Em relação ao perfil dos Conselheiros Municipais de Educação, os estudos apontaram algumas características, que merecem destaque: equilíbrio na representatividade 
com relação ao gênero, totalizando 6 mulheres e 5 homens no período analisado; predominância de conselheiros com idade entre 34 e 41 anos de idade, porém a faixa etária dos entrevistados apontou para uma média de 44 anos, demonstrado um grau de maturidade considerável, que tende a facilitar os debates e as tomadas de decisões no âmbito do Conselho; formação acadêmica com predominância de graduação em pedagogia e especializações em áreas afins a orientação pedagógica, sendo 6 conselheiros nesta categoria. Os demais se dividem em História, Administração, Ensino Médio, Educação de Jovens e Adultos e Ensino Fundamental incompleto.

Dando continuidade, outro ponto a se destacar é área de atuação no mercado de trabalho, sendo a maioria professores das três esferas de governo (Federal, Estadual e Municipal). Os representantes dos pais atuam como "dona de casa" e porteiro, respectivamente. Essa heterogeneidade na composição do Conselho tende a ser positiva, pois enriquece os debates e auxilia na tomada de decisões. A Assessoria Técnica geralmente participa das reuniões plenárias, a convite da Presidência do Conselho, principalmente quando a pauta exige análises mais aprofundadas sobre assuntos polêmicos, a exemplo da legislação sobre estágio supervisionado e denúncias sobre escolas irregulares. Dos 11 conselheiros entrevistados, somente um conselheiro mora fora do município, o que fere a legislação municipal que rege o pleno funcionamento do Conselho de Educação.

No que tange à frequência dos Conselheiros nas 38 reuniões plenárias, de acordo com as atas analisadas, foi identificado um percentual considerado alto, ou seja, $81 \%$ dos Conselheiros, das diversas representatividades, demonstraram comprometimento em relação à assiduidade e pontualidade nas convocações das reuniões ordinárias, sempre justificando possíveis ausências.

A expectativa em relação à criação e implementação do Observatório da Educação é bastante positiva. A articulação do pesquisador com o Coordenador do Observatório do Mundo do Trabalho e Pró-Reitor de Assuntos Institucionais (representantes da Reitoria), com o Gerente de Pesquisa, Pós-Graduação e Extensão e com o Diretor-Geral (representantes do Câmpus Luziânia) apontam para a materialização do produto técnico proposto como exigência de intervenção na realidade deste Mestrado Profissional em Educação. Os documentos institucionais que se encontram nos anexos corroboram para tal perspectiva e apontam o dia 15 de dezembro de 2015, como prazo final para oficializar e proporcionar materialidade a tal iniciativa, em processo de análise e implementação. 
Após essa experiência de quase dois anos no Mestrado Profissional da Faculdade de Educação da Universidade de Brasília - UnB, concluo o trabalho reiterando o compromisso com os valores democráticos, participativos e na perspectiva do controle social apontados desde o início, sem entretanto, considerar todas as contradições inerentes à temática pesquisada. 


\section{Referências Bibliográficas}

ABBAGNANO, Nicola. Dicionário de filosofia. 6. Ed. São Paulo: WMF Martins Fontes, 2012.

ALMEIDA, Carla; TATAGIBA, Luciana. Os conselhos gestores sob o crivo da política: balanços e perspectivas. Serv. Soc. Soc., n.109, p. 68-92, 2012.

ALMEIDA, Ney Luis Teixeira. O Serviço Social na Educação: Novas perspectivas sociais. In: Simpósio Mineiro de Assistentes Sociais. Anais. Belo Horizonte, 2007.

ALVAREnGA, Márcia S. (org.). Educação Popular, Movimentos Sociais e Formação de Professores: outras questões, outros diálogos. Rio de Janeiro: UERJ, 2012.

ANDRADE, Thales Novaes de. Aspectos sociais e tecnológicos das atividades de inovação. Lua Nova, São Paulo, 66: 139-166, 2006. Disponível em: $<$ http://www.scielo.br/pdf/ln/n66/29087.pdf $>$. Acesso em: 15 de fevereiro de 2015

ANDRÉ, M. Estudo de caso em Pesquisa e Avaliação Educacional. Brasília: Líber Livro, 2005 .

ANTUNES, Ricardo. Adeus ao Trabalho?: ensaio sobre as metamorfoses e a centralidade do mundo do trabalho. Campinas/SP: Cortez/Unicamp, 1995.

. Os sentidos do trabalho: ensaio sobre a afirmação e a negação do trabalho. 6. Ed. São Paulo: Boitempo Editorial, 2009.

ARANHA, Maria Lúcia de Arruda. Filosofia da Educação. 3. Ed. São Paulo, Moderna, 2006.

ARISTÓTELES. A política. São Paulo: Saraiva, 2011.

AVRITZER, Leonardo (org.). Sociedade Civil e democratização. Belo Horizonte: Del Rey, 1994.

BARDIN, Laurence. Análise de Conteúdo. Trad. Luís Antero Reto e Augusto Pinheiro. Lisboa: Edições 70, 1977.

Análise de Conteúdo. Lisboa: Edições 70, 2010.

BARROCO, Maria Lúcia S. Barbárie e Neoconservadorismo: Os desafios do Projeto ÉticoPolítico. Serv. Soc. Soc., São Paulo, n. 106, p. 205-218, abr./jun. 2011.

BASTOS, Celso Ribeiro. Comentários à Constituição Federal brasileira. São Paulo: Saraiva, 1988. 
BEHRING, Elaine R.; BOSCHETTI, Ivanete. Política Social: Fundamentos e História. São Paulo: Cortez, 2008.

BERG, B. L. Qualitative Research Methods for the Social Sciences.Boston: Allynand Bacon, 1998.

BERTRAN, Paulo. História da terra e do homem do Planalto Central:Eco-historiador. Distrito Federal: do indígena ao colonizador. Brasília. Verano, 2000.

BOBBIO, Norberto. Estado, governo e sociedade: por uma teoria geral da política. 9. Ed. São Paulo: Paz e Terra, 2001.

BOBBIO, Norberto; MATTEUCCI, Nicola; PASQUINO, Gianfranco. Dicionário de Política. Tradução Carmen C. Varrialle et al. 4. ed. Brasília: Editora Universidade de Brasília, 1998.

BOURGUIGNON, Jussara Ayres. A particularidade histórica da pesquisa no Serviço Social.São Paulo: Vera Editora; Ponta Grossa, PR: Editora UEPG, 2008.

BRASIL, Constituição (1998). Constituição da República Federativa do Brasil. Brasília, DF: Senado Federal: Centro Gráfico, 1998.

BRASIL, Lei de Diretrizes e Bases da Educação. Lei número 9394, de 20 de dezembro de 1996. Brasília, DF: Senado Federal: Centro Gráfico, 1996.

BRASIL, Ministério de Desenvolvimento Social e Combate à Fome. Presidência da República. Política Nacional de Assistência Social - PNAS. Brasília, 2004.

BRAVO, Maria Inês Souza. Desafios atuais do controle social no Sistema Único de Saúde (SUS). Serviço Social \& Sociedade, São Paulo, n. 88, 2006.

BRAVO, Maria Inez Souza; CORREIA, Maria Valéria Costa. Desafios do controle social na atualidade. Revista Serviço Social \& Sociedade. Número 109. São Paulo: Cortez, 2012.

BRESSAN, Carla Rosane. Serviço Social na Educação. Brasília: CFESS, 2001.

BRESSER PEREIRA, L. C. A reforma do Estado dos anos 90. Cadernos do Mare, n.1, Brasília, 1997.

CAMPOLINA, L. de O. Inovação educativa e subjetividade: a constituição da dimensão histórico-subjetiva implicada em um projeto inovador. Tese de doutorado não publicada. Universidade de Brasília, Brasília, 2012.

CARDOZO, Ricardo Magalhães Dias. Gestão participativa na Educação Profissional e Tecnológica: o papel do Conselho Diretor. Um estudo do Instituto Federal Norte de Minas Gerais - Câmpus Salinas - MG. Dissertação (Mestrado em Educação) Faculdade de Educação - Universidade de Brasília - UnB, Brasília - DF. 2010.

CASTEL, Robert. As metamorfoses da questão social: uma crônica do salário. 5. Ed. Rio de Janeiro: Vozes, 1998. 
Vozes,2005.

Robert. A insegurança social: o que é ser protegido?. Petrópolis, RJ:

CHRYSÓTOMO, Denise de Moura Junca. Reconceituação do Serviço Social: 40 anos. Revista Serviço Social \& Sociedade. São Paulo, Ano XXVI, 2006.

CORREIA, Maria Valéria Costa. Desafios para o controle social: subsídios para a capacitação de conselheiros de saúde. Rio de Janeiro: Fiocruz, 2005.

COUTO, Berenice Rojas et al. O Sistema Único de Assistência Social no Brasil: Uma realidade em movimento. São Paulo: Cortez, 2011.

COSTA, Tânia da. A participação do conselho popular de saúde na dinâmica deliberativa do conselho municipal de saúde de Diadema/SP: um processo em questão - 20082010. Dissertação (Mestrado acadêmico em Serviço Social). Pontifícia Universidade Católica de São Paulo, 2012.

COUTINHO, Carlos Nelson. Gramsci: um estudo sobre seu pensamento político. Rio de Janeiro: Civilização Brasileira, 1999.

Paulo: Cortez, 2006.

Carlos Nelson. Intervenções: o Marxismo na batalha das ideias. São

O leitor de Gramsci: escritos escolhidos: 1916 - 1935. Rio de Janeiro:

Civilização Brasileira, 2011.

CRESWELL, J. W. Projeto de pesquisa: métodos qualitativo, quantitativo e misto. Porto Alegre: Artmed, 2007.

Projeto de Pesquisa:Métodos qualitativo, quantitativo e Misto: Tradução de Magda Lopes. 3. Ed. Porto Alegre / RS. Artmed. 2010.

CUNHA, Luiz Antônio. Ensino profissional na irradiação do industrialismo. São Paulo: Editora UNESP; Brasília: Flacso, 2005.

\section{. O Ensino de Ofícios Artesanais e Manufatureiros no Brasil}

Escravocrata. 2. Ed. São Paulo: Editora UNESP; Brasília: Flacso, 2005.

DEMO, Pedro. Participação é conquista: noções de política social participativa. 3. Ed. São Paulo: Cortez, 1996.

DIAS, Reinaldo. MATOS, Fernanda. Políticas Públicas: princípios, propósitos e processos. São Paulo: Atlas, 2012.

DINIZ, C., CROCCO, M. A. Reestruturação econômica e impacto regional: o novo mapa da indústria brasileira. Nova Economia, Belo Horizonte, v. 6. n. 1, 1996.

DOMBROWSKI, Osmir. Poder local, hegemonia e disputa: os Conselhos Municipais em pequenos municípios do interior. Revista de Sociologia e Política, Curitiba, v. 16, n. 30, p. 269-281, jun. 2008. 
DOWBOR, Ladislau. O que é poder local? São Paulo: Brasiliense, 1994.

. A Reprodução Social.v. 3. Petrópolis: Vozes. 2003.

. O que é poder local. São Paulo: Brasiliense, 2008.

FALEIROS, Vicente de Paula. Serviço Social nas instituições: hegemonia e prática. Serviço Social \& Sociedade, ano VI, n. 17, 30 abr. 1985.

FARAH, Marta Ferreira Santos. Inovação e governo local no Brasil contemporâneo. In: JACOBI, Pedro; PINHO, José Antônio (Orgs.). Inovação no campo da gestão pública local: novos desafios, novos patamares. Rio de Janeiro: FGV, 2006.

Parcerias, novos arranjos institucionais e políticas públicas no Brasil.

Cadernos Gestão Pública e Cidadania, São Paulo, v. 18, p. 5-31, abril 2000.

FERRETI, C. J. A inovação na perspectiva pedagógica. Em Garcia, W. E. Inovação Educacional no Brasil: problemas e perspectivas. 3. Ed. Campinas, SP: Autores Associados, 1995.

FERREIRA, Norma S. A. As pesquisas denominadas Estado da Arte. Educação \& Sociedade, ano XXIII, n ${ }^{0}$ 79, Agosto de 2002.

FIGUEIREDO, Lenil da Costa. A sociedade civil nos Conselhos de Assistência Social em Mato Grosso e os desafios da participação nos municípios de pequeno porte. Dissertação (Mestrado Acadêmico em Política). Universidade Federal de Mato Grosso, 2011.

FONSECA, Igor Ferraz da; BURSZTYN, Marcel; MOURA, Adriana Maria Magalhães de. Conhecimentos técnicos, políticas públicas e participação: o caso do Conselho Nacional do Meio Ambiente (CONAMA). Rev. Sociol. Polit., vol.20, n.42, p. 183-198, 2012.

FRANÇA, L. Educação sexual: uma análise da concepção dos professores de duas escolas estaduais do ensino fundamental de Curitiba. Dissertação (Mestrado) - UTP, Tuiuti do Paraná, 2008.

FREIRE, Paulo. Poesias. Disponível em: http://www.paulofreire.org/poesias. Acesso em 30/07/2014.

Pedagogia da Autonomia. (24ª edição), São Paulo: Paz e Terra, 2002.

Pedagogia da autonomia: saberes necessários à prática educativa. São Paulo: Paz e Terra, 2011.

Educação como prática da liberdade. 14. Ed. Rio de Janeiro: Paz e Terra,

2011. 
GARCIA, July Carlos. Participação Política no Conselho Municipal de Assistência Social de Franca/SP: desafios e perspectivas. Dissertação (Mestrado Acadêmico em Serviço Social). Universidade Estadual Paulista Júlio de Mesquita Filho, Franca/SP, 2011.

GENTILI, Pablo (Org.). Pedagogia da exclusão: crítica ao neoliberalismo em educação. 19. Edição - Petrópolis, RJ. Vozes, 2013.

GERSCHMAN, Silvia. A democracia inconclusiva: Um estudo da reforma sanitária brasileira. 2. Ed. Rio de Janeiro. Fiocruz. 2004.

GIL, Antônio Carlos. Como elaborar projetos de pesquisa. 4. Ed. São Paulo: Atlas, 2002.

GOHN, Maria da Glória. Movimentos sociais e Educação. São Paulo: Cortez, 8. ed. 2012. . Movimentos sociais na contemporaneidade. Revista Brasileira de Educação, v. 16, n. 47, p. 333-361, 2011.

GRAMSCI, A. (CDH) Concepção Dialética da História. 8. ed. Rio de Janeiro: Civilização Brasileira, 1989.

1996.

Cadernos do Cárcere. Volume 1. Rio de Janeiro: Civilização Brasileira,

GUIMARÃES-IOSIF, Ranilce (Org.). Política e governança educacional: contradições e desafios na promoção da cidadania. Brasília, DF: Universa: Liber Livro, 2012.

HÖFLING, Eloisa de Mattos. Estado e políticas (públicas) sociais. Cadernos Cedes, vol. 21, n. 55, Campinas, nov. 2001.

IAMAMOTO, Marilda Villela. Serviço Social em Tempo de Capital Fetiche: Capital financeiro, trabalho e questão social. São Paulo: Cortez. 2008.

IBGE 2010: INSTITUTO BRASILEIRO DE GEOGRAFIA E ESTATÍSTICA (IBGE). Perfil dos municípios brasileiros em 2009. Rio de Janeiro, 2010

ILVEIRA, Adja Maria de Oliveira. A atuação dos Conselheiros Tutelares de Manaus na defesa e garantia dos direitos de crianças e adolescentes vítimas de violência doméstica. Dissertação (Mestrado Acadêmico em Serviço Social). Pontifícia Universidade Católica do Rio de Janeiro, 2011.

JACOBI, Pedro. Poder local, políticas sociais e sustentabilidade. Saúde e Sociedade, 1999.

JOHNSON, R. Burke; ONWUEGBUZIE, Anthony J. Mixed methods research: a research paradigm whose time has come. Educational Researcher, v.33, n.7, p.14-26, 2004.

LAVALLE, Adrian Gurza; HOUTZAGER, Peter P.; CASTELLO, Graziela. Representação política e organizações civis: novas instâncias de mediação e os desafios da legitimidade. Rev. bras. Ci. Soc., vol.21, n.60, p. 43-66, 2006. 
LIMA, T. C. S.; MIOTO R. C. T. Procedimentos metodológicos na construção do conhecimento científico: a pesquisa bibliográfica. Katálysis, Florianópolis. V. 10 n. esp., p. 37-45, 2007.

LUCHMANN, Lígia Helena Hahn. Participação e representação nos conselhos gestores e no orçamento participativo. Cad. CRH, vol.21, n.52, p. 87-97, 2008.

MACHADO, Lucília R. de Souza. Educação e Divisão Social do Trabalho: Contribuição para o estudo do ensino técnico industrial brasileiro. São Paulo: Autores Associados: Cortez, 1982.

MAANEN, J. Van, 1979. Reclaiming qualitative methods for organizational research: a preface. In Administrative Science Quarterly, v.24, n.4, December 1979, p. 520-526, apud Neves, J. L., 1996, Pesquisa Qualitativa - Características, usos e possibilidades, Caderno de Pesquisas em Administração, São Paulo, v.1, n.3, $2^{\circ}$ sem./1996. Disponível em $<$ http://www.ead.fea.usp.br/cad-pesq/arquivos/c03-art06.pdf $>$. Acesso em 21/07/2015.

MARQUES, Eduardo César. Notas críticas à literatura sobre estado, políticas estatais e atores políticos. BIB, Rio de Janeiro, n.43, $1^{\circ}$ semestre, p. 67-102, 1997.

MARX, Karl; ENGELS, Friedrich. A ideologia alemã.São Paulo: Martin Claret, 2004.

Manifesto Comunista. São Paulo: Boitempo, 2010.

.A Guerra Civil na França. São Paulo, Global, 1986.

. As Lutas de Classes na França. São Paulo, Global, 1986.

O Dezoito Brumário e Cartas a Kugelmann. $5^{\text {a }}$ edição, Rio de Janeiro, Paz e Terra, 1986.

MELO, Sônia Izabel Martins de Oliveira. Fundamentos, atribuições e abrangências legais do Conselho Municipal de Educação de Luziânia - GO - CMEL. Luziânia, GO: Conselho Municipal de Educação, 2014.

MINAYO, M. Pesquisa Social: Teoria metodológica e criatividade. São Paulo: Vozes, 1994.

MORAES, Alexandre de. Direito Constitucional. 21 ${ }^{\text {a }}$ Ed. São Paulo: Jurídico Atlas, 2007.

MOREIRA, Iumara Antunes. Análise da representatividade do segmento dos usuários no Conselho Municipal de Saúde no Município de Pelotas. Dissertação (Mestrado Acadêmico em Política Social). Universidade Católica de Pelotas, 2011.

MORIN, Edgar. Os sete saberes necessários à educação do futuro. São Paulo: Cortez, 2001.

Educar na era planetária. São Paulo: Cortez, 2003. 
Introdução ao pensamento complexo. Tradução de Eliane Lisboa. 3.ed. Porto Alegre: Sulina, 2007. MORIN, Edgar. Meu caminho: entrevistas com Djénane Kareh Tager. Tradução de Edgar Assis Carvalho e Mariza Perassi Bosco. Rio de Janeiro: Bertrand Brasil, 2010.

MORIN, Edgar, CIURANA, Emilio-Roger, MOTTA, Raúl Domingo. Educar na era planetária: o pensamento complexo como método de aprendizagem no erro e na incerteza humana. Tradução de Sandra Trabucco Valenzuela. 3.ed. São Paulo: Cortez, 2009.

MULLER, Friedrich. Quem é o povo? A questão Fundamental da democracia. São Paulo: Max Limonad, 1998.

NETTO, José Paulo. Transformações Societárias e Serviço Social: notas para uma análise prospectiva da profissão no Brasil. São Paulo: Cortez, 1996.

NEVES, Ângela; V. CASTRO, Alba Tereza Barroso de (org.). Democracia, Sociedade Civil e Serviço Social: uma perspectiva crítica. Brasília, DF: Editora Universidade de Brasília, 2012.

NOVAES, Regina; VANNUCHI, Paulo (org.). Juventude e Sociedade: trabalho, educação, cultura e participação. São Paulo: Editora Fundação Perseu Abramo, 2004.

OBSERVATÓRIO DO PNE. Política Nacional de Educação. Disponível em < http://www.observatoriodopne.org.br/pne/legislacao>. Acessado em 15 de junho de 2015.

OLIVEIRA, A. A. S. Formas de organização escolar: desafios na construção de uma escola inclusiva. In: OMOTE, Inclusão: intenção e realidade. Marília, SP: Fundepe Publicações, 2004.

OLIVEIRA, Dalila Andrade. Política educacional nos anos 1990: educação básica e empregabilidade. In: DOURADO, Luiz Fernandes; PARO Vitor Henrique. (org.). Políticas públicas e educação básica. São Paulo: Xamã, p. 105-122, 2001.

OLIVEIRA, Fabiana Noronha de. Política Pública de atendimento à criança e ao adolescente nas perspectivas do CMDCA, CT e famílias. Dissertação (Mestrado Acadêmico em Economia Doméstica). Universidade Federal de Viçosa, 2011.

OLIVEIRA, Romualdo Portela; ADRIÃO, Thereza (Orgs.). Gestão, Financiamento e Direito à Educação: Análise da LDB e da Constituição Federal. 2 Ed. São Paulo: Xamã, 2002.

OLIVEIRA, Virgílio Cézar da Silva; PEREIRA, José Roberto; OLIVEIRA, Vânia A. R. de. Os conselhos gestores municipais como instrumentos da democracia deliberativa no Brasil. Cad. EBAPE. BR, vol.8, n.3, p. 422-437, 2010.

PACHECO, Eliezer. SETEC/MEC:Bases para uma política nacional de EPT (2008). Brasília, DF: $\quad$ SETEC/MEC, 2008. Disponível em: $<$ http://portal.mec.gov.br/setec/arquivos/pdf2/artigos_bases.pdf $>$. Acesso em: 13/11/2014. 
PLANO MUNICIPAL DE EDUCAÇÃO. Plano Municipal de Educação do município de Luziânia - GO, 2015.

RAICHELIS, Raquel. Democratizar a gestão das políticas sociais: um desafio a ser enfrentado pela sociedade $\quad$ civil. 2006.20 Disponível $<$ http://www.fnepas.org.br/pdf/servico_social_saude/texto1>. Acesso em 11.02.2015.

RAICHELIS, Raquel. Articulação entre os conselhos de políticas públicas: uma pauta a ser enfrentada pela sociedade civil. 2005. Paper.

REIS, Gelmires. Almanach de Santa Luzia para 1920. Luziânia; Typographia d'O Planalto, 1929.

RÊSES, Erlando da Silva. De vocação para profissão: sindicalismo docente da educação básica no Brasil. Brasília: Paralelo 15, 2015.

RIBEIRO, João Ubaldo. Política: quem manda, por que manda, como manda. Rio de Janeiro: Nova Fronteira, 1981.

RIBEIRO, Maria Luisa Santos. História da Educação Brasileira: A organização escolar. 2 Ed. Revista. São Paulo: Cortez \& Moraes, 1979.

RIBEIRO, Natalina. Sujeitos e projetos em disputa na origem dos conselhos de políticas públicas. 2011. 242f. Tese (Doutorado em Serviço Social). Pontifícia Universidade Católica, São Paulo, 2011.

ROCHA, Carlos Vasconcelos. Gestão pública municipal e participação democrática no Brasil. Rev. Sociol. Polit. vol.19 no.38 Curitiba Feb. 2011.

ROCHA, Victor Vieira da. O Poder político no município de Luziânia/GO: A Trajetória das famílias tradicionais. $8^{\circ}$ Seminário de iniciação científica e tecnológica. PIBIC/CNPQ, 2012.

SAES, Decio. Coronelismo e Estado Burguês: elementos para uma reinterpretação. In: Estado e Democracia: Ensaios teóricos. Coleção Trajetória 1. 2.ed. Campinas: Unicamp, IFCH, 1998.

SAVIANI, Dermeval. Da nova LDB ao FUNDEB: por outra política educacional. 4.ed. Campinas, SP: Autores Associados, 2011 (Coleção educação contemporânea).

Associados, 2007. . História das idéias pedagógicas no Brasil. Campinas, SP: Autores

SCHERER-WARREN, Ilse. Cidadania sem fronteiras: ações coletivas na era da globalização. São Paulo: Hucitec,1999.

SERRA, Rose M. S. Crise de materialidade no serviço social: repercussões no mercado profissional. São Paulo: Cortez, 2000. 
Sociedade e Estado, 2006.

Das mobilizações às redes de movimentos sociais. Brasília:

SILVA, Maria Ozanira da Silva e. Pobreza, desigualdade e políticas públicas: caracterizando e problematizando a realidade brasileira. Rev. Katál. Florianópolis v. 13 n. 2 p. 155-163 jul./dez. 2010.

SILVA, Marcela Mary José. A materialização do Projeto Ético-Político do Serviço Social. Campinas. São Paulo: Papel Social, 2012.

Papel Social, 2012.

(org.). Serviço Social na Educação: Teoria e Prática. Campinas, São Paulo:

SILVA, José Afonso Da. Curso de Direito Constitucional Positivo. $28^{\mathrm{a}}$ Ed. Brasil: Malheiros, 2007.

SOUZA, A.R.DE. Perfil da gestão escolar no Brasil. Tese (Doutorado em Educação: História. Políticas, Sociedade). Pontífica Universidade católica de São Paulo, São Paulo, 2006.

SOUZA. D.B. DE (Org.). Acompanhamento e controle social da educação: fundos e programas federais e seus locais. São Paulo: Xamã, 2006.

SIPIONI, Marcelo Eliseu; SILVA, Marta Zorzal. Reflexões e interpretações sobre a participação e a representação em conselhos gestores de políticas públicas. Rev. Sociol. Polit., vol.21, n.46, p. 147-158, 2013.

STRAUSS, A.; CORBIN, J. Pesquisa qualitativa: técnicas e procedimentos para o desenvolvimento de teoria fundamentada. Porto Alegre: Artmed, 2008.

TAVARES, M.A.S. O S. S. no contexto da reestruturação produtiva: $O$ mercado Profissional de trabalho no município de Volta Redonda - RJ. Dissertação, PGPSS. 2008. UERJ - RJ.

TEIXEIRA, Sandra Oliveira. Participação e controle democrático sobre o orçamento público federal em um contexto de crise do capital. 2012. Tese (Doutorado em Serviço Social) - Universidade Estadual do Rio de Janeiro, Rio de Janeiro. 2012.

TELLES, Vera da Silva. Sociedade civil e a construção de espaços públicos. In: DAGNINO, Evelina (Org.). Anos 90: Política e Sociedade no Brasil. São Paulo: Brasiliense, 1994.

TORMIN, Cassiana Vaz. Um lugar e suas raízes: o pensamento político em Luziânia GO. Dissertação de Mestrado - Departamento de Geografia da Universidade de Brasília, 2004. 


\section{Anexos}

ANEXO I - Declaração de Autorização para Pesquisa de Campo

ANEXO II- Documento da Reitoria autorizando a Criação do Observatório

ANEXO III - Documento da Diretoria-Geral autorizando a Criação do Observatório

ANEXO IV - Documento da Diretoria-Geral autorizando a Criação do Observatório

ANEXO V - Termo de Consentimento das Entrevistas

ANEXO VI - Termo de Consentimento das Entrevistas (Gestor do IFG)

ANEXO VII - Sítio na Internet do Observatório do Mundo do Trabalho 


\section{Anexo I - Declaração de Autorização para Pesquisa de Campo}
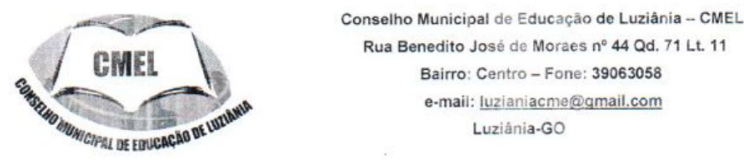

DECLARAÇÃO

Declaro para os fins que se faz necessário que o Servidor Público Federal Josemar de Assis Oliveira, Assistente Social do Quadro Efetivo do Instituto Federal de Goiás - IFG - Câmpus Luziânia, é aluno regular do Curso de Mestrado Profissional em Educação da Universidade de Brasilia e foi devidamente autorizado a pesquisar "A Relação do Conselho Municipal de Educação com o Instituto Federal de Goiás (IFG) em Luziânia: UM ESTUDO DO CONTROLE SOCIAL NUMA PERSPECTIVA DEMOCRÁTICA", sob a orientação do Professor Doutor Erlando da Silva Rêses. Vale ressaltar que o referido Servidor sempre contribuiu com as ações do Conselho Municipal, assessorando e propondo intervenções sistemáticas junto ao Sistema Municipal de Ensino. Declaro ainda que entendo que essa pesquisa será de grande relevância para o desenvolvimento local e regional, e todos os documentos do Conselho foram disponibilizados para consultas e análises, a exemplo de atas, resoluções e pareceres no período de 15 de outubro de 2013 a 15 de abril de 2015 , sob a minha Gestão como Presidente.

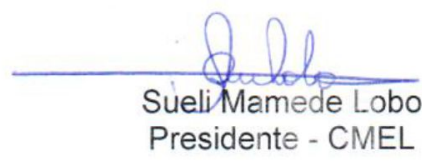




\section{Anexo II - Documento da Reitoria autorizando a Criação do Observatório}

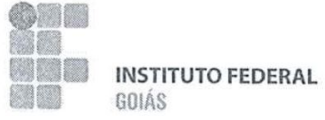

Memorando 05 /MEC/IFG/OMT

\author{
MNISTÉRIO DA EDUCAÇÄO \\ SECRETARIA DE EDUCAÇÄO PROFISSIONAL E TECNOLÓGICA \\ INSTITUTO FEDERAL DE EDUCAÇÄO, CIÊNCIA E TECNOLOGIA DE GOIÁS \\ PRÓ-REITORIA DE DESENVOLVIMENTO INSTITUCIONAL \\ OBSERVATÓRIO DO MUNDO DO TRABALHO
}

Goiânia, 23 de junho de 2015.

Do: Observatório do Mundo do Trabalho e Pró-Reitoria de Desenvolvimento Institucional. Para: Diretor-Geral do Câmpus Luziânia - Prof. José Carlos Barros Silva

Assunto: Comunicação de encaminhamentos para a criação de um Núcleo de Base do Observatório do Mundo do Trabalho no Câmpus Luziânia do IFG.

Prezado dirigente, conforme tratativas do senhor Josemar Assis Oliveira, servidor lotado no Câmpus Luziânia no cargo de Assistente Social com o Servidor Geraldo Coelho de Oliveira Júnior, Coordenador do Observatório do Mundo do Trabalho, estamos realizando estudos para constituirmos nesse Câmpus, um Núcleo de Base do Observatório do Mundo do Trabalho.

O Observatório do Mundo do Trabalho do IFG tem como objetivos desenvolver e socializar metodologias, estudos/pesquisas e experiências para a consolidação do IFG e o fortalecimento da Rede Federal de Educação Profissional, Científica e Tecnológica, nesse sentido, aglutinar pesquisadores e constituir núcleos agregados é essencial para o bom cumprimento desse propósito.

Destaca-se também que continuamos tendo necessidade de estruturação de um quadro multidisciplinar de pesquisadores, o que pode ser realizado com a constituição desses núcleos de base. Agregar novos pesquisadores e ampliar as possibilidades de formação é de suma importância para a viabilização dos trabalhos que são demandados a esse Observatório.

Nesse sentido, solicitamos o seu apoio para podermos realizar os encaminhamentos necessários a criação desse Núcleo de base, sem prejuízo das funções já estabelecidas para o

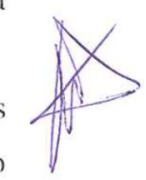

Reitoria do Instituto Federal de Educação, Ciência e Tecnologia de Goiás Av. Assis Chateaubriand, no 1.658, Setor Oeste. CEP: 74.130-012. Goiânia-GO Fone: (62) 3612-2248 


\section{MNISTERIO DA EDUCAÇÃO}

SECRETARIA DE EDUCAÇÄO PROFISSIONAL E TECNOLÓGICA

$\begin{array}{ll}\text { INSTITUTO FEDERAL } & \text { INSTITUTO FEDERAL DE EDUCAÇÄO, CIÊNCIA E TECNOLOGIA DE GOIÁS } \\ \text { GOIÁS } & \text { PRÓ-REITORIA DE DESENVOLVIMENTO INSTITUCIONAL }\end{array}$ ORO-REITORIA DE DESENVOLVIMENTO INSTITUCIONAL

servidor Josemar Assis Oliveira e também sem prejuízo das prioridades de planejamento já estabelecidas por esse Câmpus.

Desde já agradecemos a atenção e nos colocamos à disposição para quaisquer esclarecimentos que porventura se fizerem necessários.

Atenciosamente,

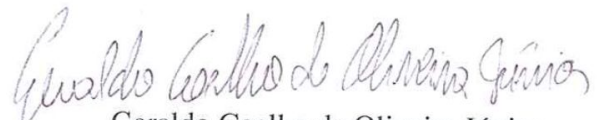

Geraldo Coelho de Oliveira Júnior

Observatório do Mundo do Trabalhẹ

De Acordo,

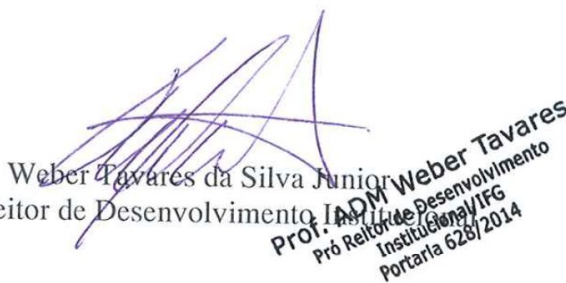

Reitoria do Instituto Federal de Educação, Ciência e Tecnologia de Goiás Av. Assis Chateaubriand, $n^{\circ}$ 1.658, Setor Oeste. CEP: 74.130-012. Goiânia-GO Fone: (62) 3612-2248 


\section{Anexo III - Documento da Diretoria-Geral autorizando a Criação do Observatório}

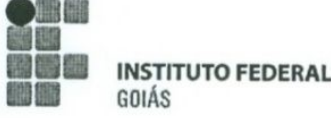

Memorando n 105/2015/GAB/IFG/Câmpus Luziânia

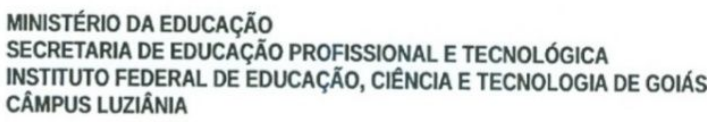

Luziânia, 09 de julho de 2015.

Ao Senhor

Geraldo Coelho de Oliveira Júnior

Coordenador do Observatório do Mundo do Trabalho - Reitoria

Assunto: Resposta ao Memorando 05/MEC/IFG/OMT.

Senhor Coordenador,

1. Conforme Memorando 05/MEC/IFG/OMT, datado em 23 de junho de 2015 e recebido nesta Diretoria-Geral em 08 de julho de 2015, referente às tratativas do Servidor Josemar de Assis Oliveira, Assistente Social deste Instituto, e de Vossa Senhoria; informamos que estamos cientes da proposta de criação de um Observatório descentralizado do Mundo do Trabalho que funcionaria no Instituto Federal de Goiás/ Câmpus Luziânia como um Núcleo de Base subordinado ao Observatório Geral do Mundo do Trabalho, e que é um projeto, oriundo dos debates no processo de orientação e banca de qualificação do Mestrado Profissional em Educação da Universidade de Brasília - UnB do Sr. Josemar de Assis Oliveira, que está sendo estruturado com a intenção de ser implantado até 15 de dezembro de 2015.

2. Ressaltamos que a criação de um Observatório do Mundo do Trabalho neste Câmpus iria ao encontro dos anseios da comunidade local, no que diz respeito à obtenção de conhecimento e socialização de metodologias, estudos e pesquisas sobre a Educação e sua relação intrínseca com o Mundo do Trabalho.

3. Desde já, agradecemos a atenção dispensada e colocamo-nos à disposição para mais esclarecimentos.

Atenciosamente,
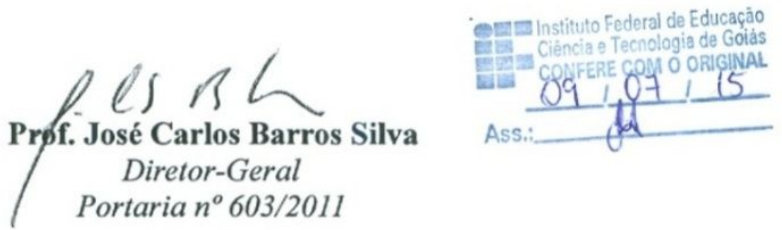

Instituto Federal de Educação, Ciência e Tecnologia de Goiás - Câmpus Luziânia Rua São Bartolomeu, s/n, Vila Esperança - CEP: 72.811-580 - Luziânia - GO wuw.ifg.edu.br / Fone: (61) 3622-9727 


\section{Anexo IV - Documento da Diretoria-Geral autorizando a Criação do Observatório

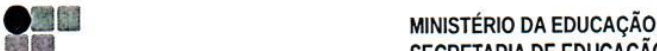 \\ SECRETARIA DE EDUCACC̃O PROFISSIONAL E TECNOLÓGICA \\ INSTITUTO FEDERAL
GOIÁS \\ INSTITUTO FEDERAL DE EDUCAÇ̃̃O, CIÊNCIA E TECNOLOGIA DE GOIÁS \\ CÂMPUS LUZIÂNIA \\ Memorando n 118/2015/GAB/IFG/Câmpus Luziânia}

Luziânia, 28 de julho de 2015.

Ao Senhor

Weber Tavares da Silva Júnior

Pró-Reitor de Desenvolvimento Institucional - Reitoria

Assunto: Resposta ao Memorando 05/MEC/IFG/OMT.

Prezado Pró-Reitor,

1. Conforme Memorando 05/MEC/IFG/OMT, datado em 23 de junho de 2015 e recebido nesta Diretoria-Geral em 08 de julho de 2015, referente às tratativas do Servidor Josemar de Assis Oliveira, Assistente Social deste Instituto, e do Sr. Geraldo Coelho de Oliveira Júnior, Coordenador do Observatório do Mundo do Trabalho; informamos que estamos cientes da proposta de criação de um Observatório descentralizado do Mundo do Trabalho que funcionaria no Instituto Federal de Goiás/ Câmpus Luziânia como um Núcleo de Base subordinado ao Observatório Geral do Mundo do Trabalho, e que é um projeto, oriundo dos debates no processo de orientação e banca de qualificação do Mestrado Profissional em Educação da Universidade de Brasília - UnB do Sr. Josemar, que está sendo estruturado com a intenção de ser implantado até 15 de dezembro de 2015.

2

Ressaltamos que a criação de um Observatório do Mundo do Trabalho neste Câmpus iria ao encontro dos anseios da comunidade local, no que diz respeito à obtenção de conhecimento e socialização de metodologias, estudos e pesquisas sobre a Educação e sua relação intrínseca com o Mundo do Trabalho.

3.

Desde já, agradecemos a atenção dispensada e colocamo-nos à disposição para mais esclarecimentos.

Atenciosamente,
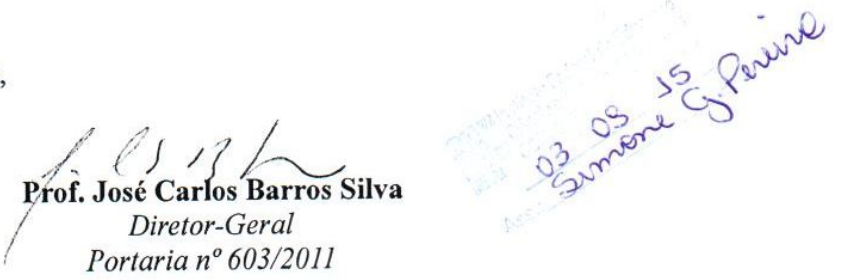

Instituto Federal de Educação, Ciência e Tecnologia de Goiás - Câmpus Luziânia Rua São Bartolomeu, s/n, Vila Esperança - CEP: 72.811-580 - Luziânia - GO wuw.ifg.edu.br / Fone: (61) 3622-9727 
ANEXO V - Termo de Consentimento das Entrevistas

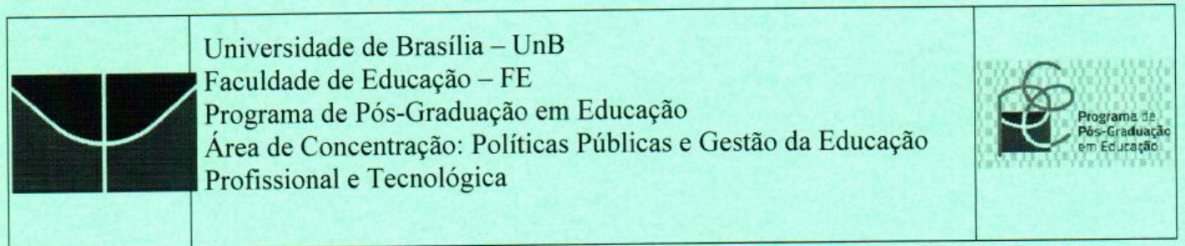

TERMO DE CONSENTIMENTO LIVRE E ESCLARECIDO

$\mathrm{Eu}$,

$\mathrm{RG} \mathrm{n}^{\circ}$ concordo em participar por minha livre e espontânea

vontade da pesquisa: "A Relação entre o Conselho Municipal de Educação e o Instituto Federal de Goiás (IFG) em Luziânia: Um Estudo do Controle Social numa perspectiva democrática a ser apresentada como Dissertação de Mestrado para a Universidade de Brasília, no Programa de Mestrado Profissional em Educação, na linha de pesquisa Políticas Públicas e Gestão da Educação Profissional e Tecnológica, sob a orientação do Prof. Dr. Erlando da Silva Rêses.

Declaro estar esclarecido (a) e informado (a) que a pesquisa visa estudar como o Instituto Federal de Goiás e o Conselho Municipal de Educação em Luziânia se relacionam, a partir da participação dos Conselheiros neste processo.

De livre e espontânea vontade responderei às perguntas referentes à minha experiência e atuação como Conselheiro Municipal de Educação. Estou ciente que esta pesquisa tem caráter estritamente acadêmico, estando totalmente desvinculada de quaisquer interesses partidários ou governamentais.

Estou ciente de que esta entrevista será gravada, transcrita e analisada pelo pesquisador e que o arquivo referente à gravação e/ou documento da transcrição da gravação serão arquivados após a finalização do estudo. Além disso, estou ciente que não serei identificado (a) no trabalho escrito ou apresentado, e que na pesquisa será utilizado um código de anonimato quando houver referência à pessoa entrevistada. Tenho garantia do sigilo aos dados confidenciais envolvidos na pesquisa e minha participação está livre de qualquer remuneração ou despesa.

Declaro também estar ciente de que durante a pesquisa, se houver dúvidas, serei esclarecido (a) pelo pesquisador responsável pelo telefone (61) 8351-5960 ou (61) 3622.9718 ou pelo correio eletrônico: joassisoliv@hotmail.com

Por fim, terei a liberdade de recusar a responder às perguntas que me causarem constrangimento, a participar ou retirar meu consentimento em qualquer fase da pesquisa, sem penalização alguma.

$\mathrm{O}$ termo foi assinado por mim e pelo pesquisador.

Entrevistado (a):

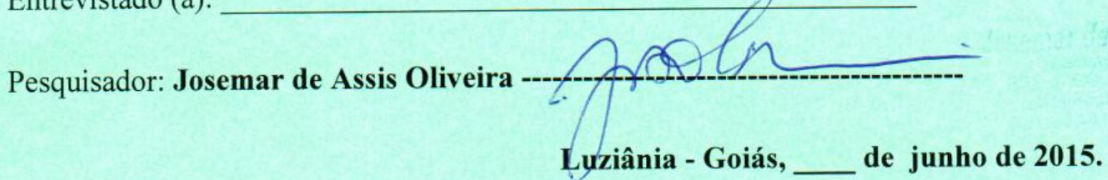




\section{ANEXO VI - Termo de Consentimento da Entrevista (Gestor IFG)}

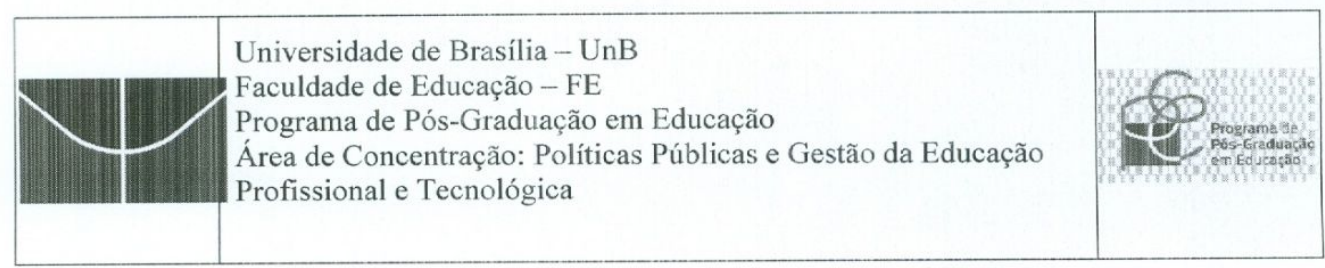

TERMO DE CONSENTIMENTO LIVRE E ESCLARECIDO

Eu, José Carlos Marros Silv2 vontade da pesquisa: "A Relação entre o Conselho Municipal de Educação e o Instituto Federal de Goiás (IFG) em Luziânia: Um Estudo do Controle Social numa perspectiva democrática a ser apresentada como Dissertação de Mestrado para a Universidade de Brasília, no Programa de Mestrado Profissional em Educação, na linha de pesquisa Políticas Públicas e Gestão da Educação Profissional e Tecnológica, sob a orientação do Prof. Dr. Erlando da Silva Rêses.

Declaro estar esclarecido (a) é informado (a) que a pesquisa visa estudar como o Instituto Federal de Goiás e o Conselho Municipal de Educação em Luziânia se relacionam, a partir da participação dơs Conselheiros e da Direção-Geral do Câmpus do IFG local neste processo.

De livre e espontânea vontade responderei às perguntas referentes à minha experiência e atuação como Gestor (Diretor-Geral) do IFG - Câmpus Luziânia - GO. Estou ciente que esta pesquisa tem caráter estritamente acadêmico, estando totalmente desvinculada de quaisquer interesses partidários ou governamentais.

Estou ciente de que esta entrevista será gravada, transcrita e analisada pelo pesquisador e que o arquivo referențe à gravação e/ou documento da transcrição da gravação serão arquivados após a finalização do estudo. Além disso, estou ciente que não serei identificado (a) no trabalho escrito ou apresentado, e que na pesquisa será utilizado um código de anonimato quando houver referência à pessoa entrevistada. Tenho garantia do sigilo aos dadoś confidenciais envolvidos na pesquisa e minha participação está livre de qualquer remuneração ou despesa.

Declaro também èstar ciente de que durante a pesquisa, se houver dúvidas, serei esclarecido (a) pelo pesquisador responsável pelo telefone (61) 8351-5960 ou (61) 3622.9718 ou pelo correìo eletrônico: joassisoliv@hotmail.com

Por fim, terei a liberdade de recusar a responder às perguntas que me causarem constrangimento, a participar ou retirar meu consentimento em qualquer fase da pesquisa, sem penalização alguma.

O termo foi assinado por mim e pelo pesquisador.

Entrevistado (a):

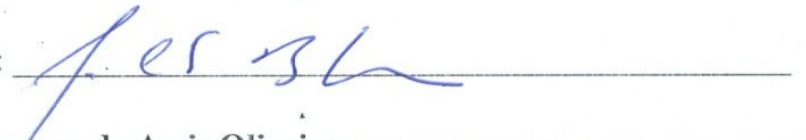

Pesquisador: Josemar de Assis Oliveira

Luziânia - Groiás, 24 de junho de 2015. 
ANEXO VII - Sítio na Internet do Observatório do Mundo do Trabalho

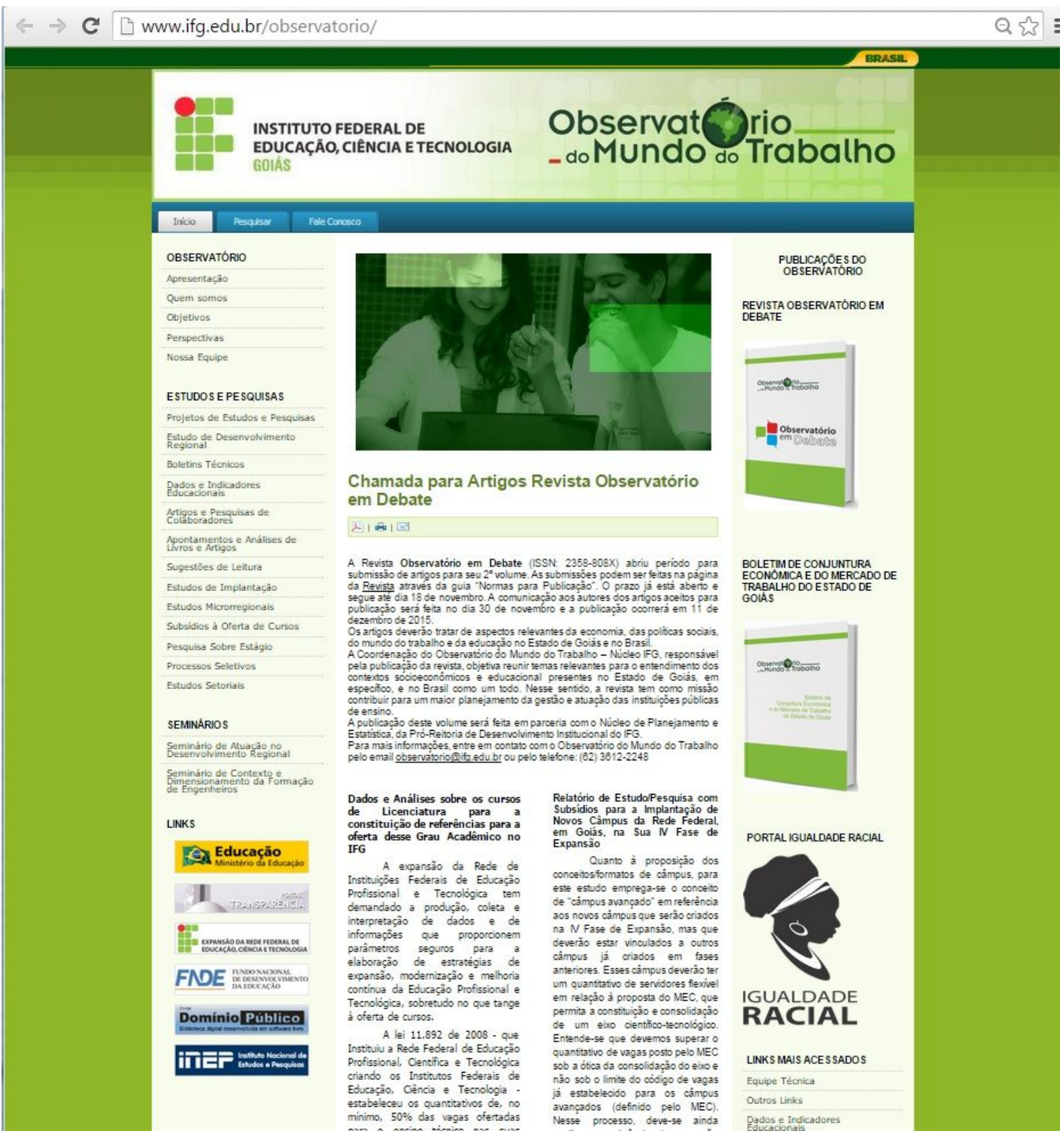

Fonte: IFG. Disponível em: <http://www.ifg.edu.br/observatorio/>. Acesso em 17/07/2015. 


\title{
Apêndice
}

\section{I - Roteiro das Entrevistas}

\author{
Apêndice I - Roteiro das Entrevistas
}

\section{Proposta de Roteiro das Entrevistas - Pesquisa de Campo Mestrado Profissional Educação UnB}

Discente: Josemar de Assis Oliveira

Orientador: Professor Dr. Erlando da Silva Reses

\section{ROTEIRO DAS ENTREVISTAS COM OS CONSELHEIROS E GESTOR IFG}

1. Qual o seu nome, Poder que representa e nome da Entidade que atua?

2. Qual a sua função no CME e tempo que atua como Conselheiro?

3. Qual é o papel social do CME na sua concepção?

4. Em sua opinião, a participação do IFG contribui com o papel do CME?

5. Na sua concepção, o IFG contribui para que o CME cumpra o seu papel de Controle Social? Como isso se dá? (se sim ou não)...

6. Em sua opinião, a presença do IFG no CME contribui para o alcance da função do CME, no sentido que outra Entidade não possa desenvolver a sua representatividade (IFG)?

7. Na sua concepção, caso o IFG venha a instituir, com recursos próprios,um Observatório de consulta pública a respeito da história de Luziânia e da prática do CME, isso se caracteriza para o alcance do papel do Conselho?

8. Tendo em vista o tema desta pesquisa de dissertação de mestrado em Educação, há algo a mais de relevante que V.Sa. gostaria de acrescentar? 